
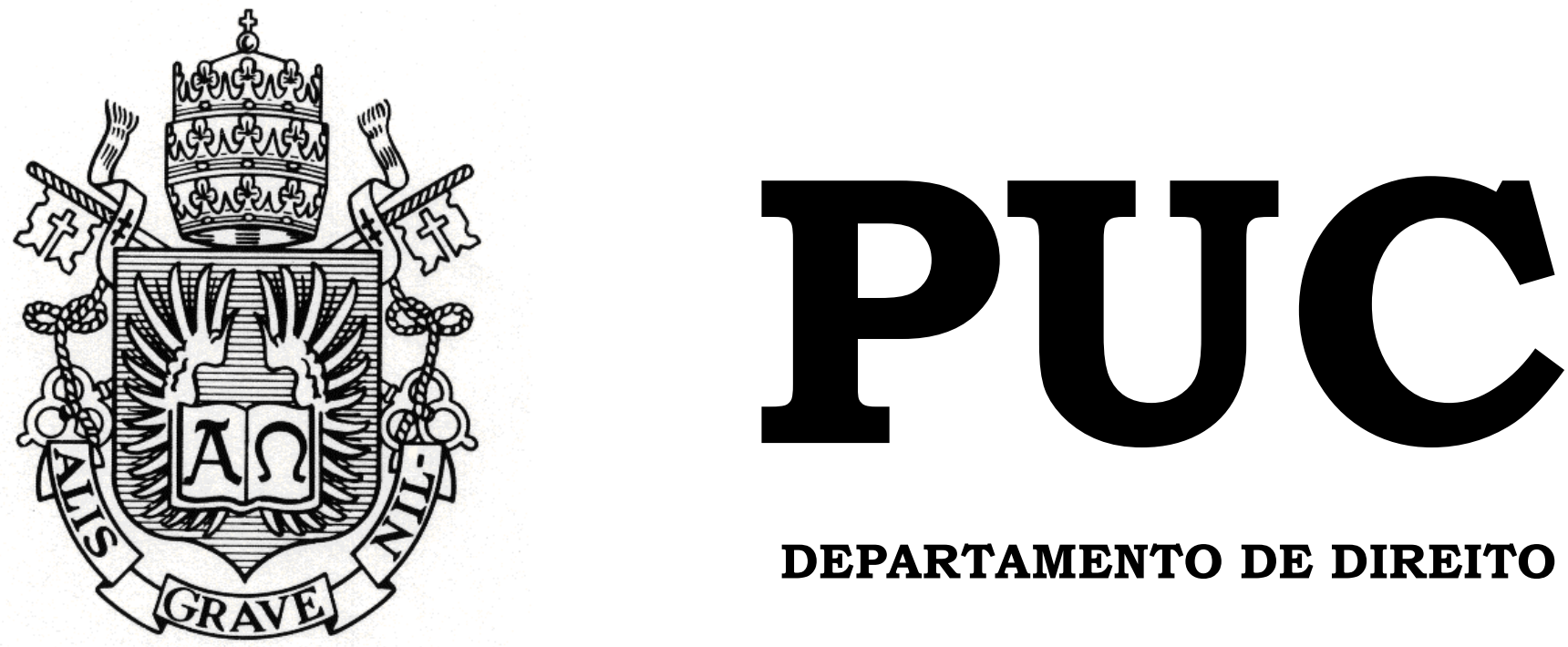

DEPARTAMENTO DE DIREITO

\title{
ATRIBUIÇÕES NORMATIVAS DO CONSELHO NACIONAL DE SAÚDE E SUAS COMISSÕES NO TOCANTE ÀS PESQUISAS CIENTÍFICAS ENVOLVENDO SERES HUMANOS
}

Por

MARCELLA LEAL RESTUM

ORIENTADOR(A): LETÍCIA DE CAMPOS VELHO MARTEL 2012.2

PONTIFÍCIA UNIVERSIDADE CATÓLICA DO RIO DE JANEIRO

RUA MARQUÊS DE SÃO VICENTE, 225 - CEP 22453-900

RIO DE JANEIRO - BRASIL 


\title{
ATRIBUIÇÕES NORMATIVAS DO CONSELHO NACIONAL DE SAÚDE E SUAS COMISSÕES NO TOCANTE ÀS PESQUISAS CIENTÍFICAS ENVOLVENDO SERES HUMANOS
}

\author{
por
}

MARCELLA LEAL RESTUM

Monografia apresentada ao Departamento de Direito da Pontificia Universidade Católica do Rio de Janeiro (PUC-Rio) para a obtenção do Título de Bacharel em Direito.

Orientador(a): Letícia de Campos Velho Martel. 


\section{AGRADECIMENTOS}

Não poderia deixar de agradecer, em primeiro lugar, à minha orientadora, Letícia de Campos Velho Martel, pela valiosa ajuda no desempenho deste trabalho e pelas importantes indicações bibliográficas, todas utilizadas nesta pesquisa.

Agradeço, também, aos meus irmãos, que estiveram sempre ao meu lado.

Devo agradecer, ainda, ao meu namorado, pela paciência, apoio e pelas sugestões preciosas, que muito contribuíram para a finalização deste trabalho.

Agradeço, por fim e principalmente, aos meus queridos pais, pela enorme dedicação que tiveram em relação à educação de seus filhos e em quem me espelho para a realização de todos os projetos em minha vida. 


\section{RESUMO}

A presente monografia pretende discutir a atuação normativa do Conselho Nacional de Saúde no tocante às pesquisas científicas com seres humanos diante do cenário atual de omissão legislativa. Sobre o tema, a análise dos princípios da legalidade e juridicidade, basilares do Estado Democrático de Direito, faz-se necessária.

Assim, em um primeiro momento, examinam-se as origens do princípio da legalidade, corolário do Estado Democrático de Direito, suas concepções e também as consequências do princípio. A partir daí, busca-se discutir as razões que levaram à releitura princípio da legalidade, momento no qual aproxima-se ao princípio da juridicidade. Cuida-se, então, de explorar este contrabalanço ao princípio da legalidade e às transformações na atividade administrativa. Ademais, procede-se a uma exposição acerca dos conceitos de lei e de regulamento, promovendo uma diferenciação entre ambas as espécies normativas e as possíveis funções da segunda no cenário pós-positivista. Em um segundo momento, apresenta-se o Conselho Nacional de Saúde, seu histórico, suas características e atribuições. Procura-se também analisar a composição e finalidade de suas diversas Comissões, com atenção especial à CONEP.

Por fim, busca-se investigar um âmbito de atribuição normativa da Administração Pública delimitado, qual seja, a viabilidade da regulamentação efetivada pelo Conselho Nacional de Saúde na questão das pesquisas científicas realizadas com seres humanos. Ou seja, o objetivo final do trabalho consiste em investigar se a atribuição normativa em questão encontra respaldo na Constituição Federal de 1988.

Palavras-chaves: Legalidade - Juridicidade - Conselho Nacional de Saúde Atribuição Normativa - Pesquisas Científicas. 
CAPÍTULO I - ATRIBUIÇÕES NORMATIVAS DA ADMINISTRAÇÃO PÚBLICA CONSOANTE OS PRINCÍPIOS DA LEGALIDADE E DA JURIDICIDADE .14

I.I - Relevância dos princípios para o Direito Administrativo 14

I.II - Algumas notas sobre a origem do Princípio da Legalidade Administrativa 19

I.III - Princípio da Legalidade: conceito e dimensões do princípio em tela.

I.IV - Da legalidade à juridicidade 34

CAPÍTULO II - NÍVEIS FUNDAMENTAIS DE FONTES DO DIREITO SUBMETIDOS À HIERARQUIA CONSTITUCIONAL: A LEI E O REGULAMENTO

II.I - A Lei. 42

II.II - Poder Regulamentar e graus de regulamentação 48

II.II.1 - A delegação disfarçada 51

II.II.2 - O controle ao poder regulamentar 52 
III.I - Breve histórico 62

III.II - Composição do Conselho 67

III.III - Estrutura organizacional. 77

III.IV - As Comissões 82

III.V - CONEP 84

III.VI - Atribuição do CNS. 89

III.VII - Dinâmica decisória 94

CAPÍTULO IV - ATRIBUIÇÃO NORMATIVA DO CNS ATINENTE ÀS PESQUISAS CIENTÍFICAS ENVOLVENDO SERES HUMANOS ..... 100

IV.I - Resolução 196/96 100

IV.II - Relevância dos direitos 104

IV.III - Atribuição normativa do Conselho Nacional de Saúde e o Estado Democrático de Direito 105

IV.III.1 - Resolução 196/96 e sua possível adequação à lei 106

IV.III.2 - Resolução 196/96: Ato normativo praeter legem? 108 
IV.III.3- Violações à lei na Resolução 196/96

IV.III.4- Resolução 196/96 e sua adequação aos ditames

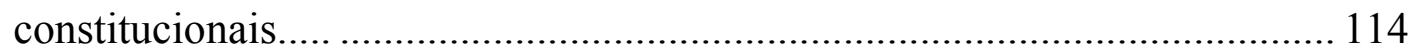

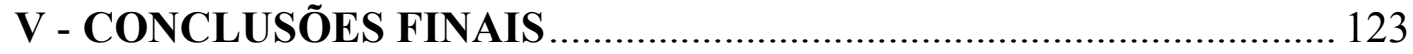

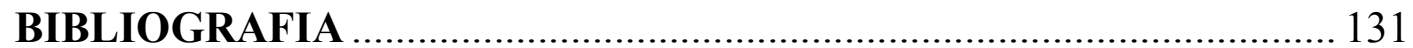

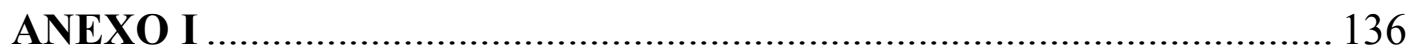




\author{
Abreviações \\ ADC - Ação Declaratória de Constitucionalidade \\ ADC/MC-Ação Declaratória de Constitucionalidade com medida cautelar \\ ADCT - Ato das Disposições Constitucionais Transitórias \\ ADI - Ação Direta de Inconstitucionalidade \\ ADPF - Arguição de Descumprimento de preceito fundamental \\ ANVISA-Agência Nacional de Vigilância Sanitária \\ Cep- Comitê de Ética em Pesquisa \\ CNJ - Conselho Nacional de Justiça \\ CNS - Conselho Nacional de Saúde \\ Conasems - Conselho Nacional de Secretários Municipais de Saúde \\ Conass - Conselho Nacional de Secretários de Saúde \\ Conep - Comissão Nacional de Ética em Pesquisa \\ Encep - Encontro Nacional dos Comitês de Ética em Pesquisa \\ GT - Grupo de Trabalho \\ SCTIE - Secretaria de Ciência, Tecnologia e Insumos Estratégicos \\ STF - Supremo Tribunal Federal \\ SUS - Sistema Único de Saúde
}




\section{INTRODUÇÃO}

Nos dias atuais, parecem não ter limite as descobertas científicas. Tais descobertas, no entanto, são resultado de pesquisas científicas que se tornam cada dia mais frequentes e que exigem a devida regulação por parte do Estado. Para muitos autores, estar-se-ia diante de uma quarta geração de Direitos Fundamentais, os direitos da Biotecnologia, que suscitariam a necessidade de uma intervenção protetiva estatal. Tal intervenção é fundamental para que os sujeitos de pesquisa ${ }^{1}$ tenham seus direitos plenamente garantidos, para que não sejam expostos a riscos devido ao vácuo normativo. Isso porque os sujeitos de pesquisa são, acima de tudo, sujeitos de direito que devem ter sua dignidade respeitada.

Nesse sentido, e partindo para uma análise do ordenamento jurídico brasileiro, observa-se que tal regulação não foi promovida pelo Poder Legislativo, mas pela Administração Pública. As pesquisas científicas vêm sendo reguladas pelo Conselho Nacional de Saúde e suas Comissões, fato este que traz à tona uma série de indagações acerca de tal atribuição normativa.

É evidente que se trata de tema com grande relevância política e jurídica, dotado de profunda densidade, e que nos leva a um cenário de inovação jurídica. Por esse motivo parece estranho que ele não seja enfrentado pelo órgão que exerce, típica e legitimamente, a função legislativa.

Diante disso, é não só atual, mas também urgente que se discuta a regulação, e principalmente, a atribuição normativa destinada a órgãos da

\footnotetext{
${ }^{1}$ De acordo com a definição dada pela Resolução CNS no 196/96, de 10 de outubro de 1996, sujeito de pesquisa é "o(a) participante pesquisado (a), individual ou coletivamente, de caráter voluntário, vedada qualquer forma de remuneração".
} 
Administração Pública no tocante às pesquisas científicas com seres humanos. Assim, faz-se necessário que se examine se a Administração Pública possui atribuição para realizar a função normatizante das pesquisas científicas, matéria que envolve sensivelmente os Direitos Fundamentais, segundo a Constituição Federal de 1988, bem como se os patamares de legitimidade se coadunam com os previstos pela Constituição.

Desta forma, em um primeiro momento será discutida a relevância dos princípios para o direito administrativo brasileiro, após a análise de sua classificação para alguns autores. Para tanto, serão abordadas as fases do normativismo do princípio, até que se chegue a fase pós-positivista. Nesse sentido, em cada uma das fases consideradas, será salientada a diferença, entre regras e princípios. Assim será possível entender a importância desta fonte do direito para o ramo específico que é o direito administrativo. Posteriormente, passar-se-á ao exame do princípio da legalidade. Tal apreciação tem como ponto de partida a investigação de suas origens, quais sejam, o liberalismo e a separação de poderes, no qual abordam-se as concepções de LOCKE, RousSEAU e MonTESQUIEU. Ademais, será também abordada brevemente a relação entre o princípio da legalidade e o surgimento do Direito Administrativo, com a observância da divergência da doutrina quanto ao último. Será então possível avançar ao exame do conceito deste princípio e de suas inúmeras concepções. Aborda-se, desta maneira, as dimensões observadas por EISENMANN, a partir de sua leitura tradicional, e as críticas à estas dimensões. Será estudada, ademais, a classificação de SÉRVUlo CORREIA, BINENBOJM e GILMAR MENDES e a concepção abarcada pelo ordenamento jurídico brasileiro. Após tais considerações, chega-se ao objetivo central deste capítulo, a saber, a investigação da ampliação do princípio da legalidade, chamado de juridicidade administrativa. Para isso, será analisado o neoconstitucionalismo, a partir das lições pós-positivistas abordadas, e ainda, as causas da chamada crise da lei, ambos fundamentais ao objetivo final do 
presente estudo. A partir de todo o exposto, é possível entender esta nova concepção do princípio da legalidade. Ademais, serão investigados os limites à juridicidade administrativa, ou seja, a possibilidade de atividade praeter legem e contra legem.

Passa-se, então, no Capítulo II à investigação acerca da lei e do poder regulamentar. Será procedida uma análise acerca dos aspectos gerais de cada um e das implicações de todo o exposto no Capítulo I acerca da superação do princípio da legalidade sobre tais atos normativos. Sobre a lei, será realizado um sobrevoo acerca de conceitos construídos pela doutrina tradicional sobre esta espécie normativa, sua atual concepção e as distinções acerca de seu aspecto formal e material. Ademais, serão abordadas as formas sob as quais se alicerçou a ideia de superioridade da lei sobre os regulamentos durante muito tempo e a contribuição dos princípios da legalidade e da separação de poderes sobre estas diferenças. Quanto ao poder regulamentar será inicialmente abordada sua concepção sob a luz de uma visão rígida do princípio da legalidade. Posteriormente, passar-se-á a análise da diferenciação entre regulamentar e regular existente para grande parte da doutrina e da função do regulamento no ordenamento jurídico brasileiro. Ademais, serão analisados temas importantes acerca do poder regulamentar, a saber, a delegação disfarçada, além das formas, espécies e controle desta atividade administrativa. Neste momento, e, tendo em vista todo o exposto no primeiro Capítulo I, será dada atenção especial à questão da classificação dos regulamentos, principalmente na atual que difere os regulamentos de execução daqueles chamados independentes. Deste modo, as partes finais do Capítulo II serão dedicadas à discussão acerca do cabimento ou não do regulamento autônomo no ordenamento jurídico brasileiro, especialmente sob este novo enfoque ocasionado pelo desenvolvimento da noção da juridicidade administrativa.

No Capítulo III, por sua vez, será feito um esboço do Conselho Nacional de Saúde, já que este é fundamental para que seja possível chegar ao 
objetivo principal deste trabalho. Destarte, o ponto inicial desta investigação acerca da instância colegiada do Ministério da Saúde, será a abordagem, em linhas gerais, do histórico da mesma, através da referência das três fases de desenvolvimento mencionadas pela doutrina. Posteriormente, será feita uma resenha acerca da composição, de extrema relevância para a discussão final do estudo, e de sua estrutura organizacional. Também serão investigadas as Comissões, com aprofundamento no trabalho realizado por estas, e, em tópico apartado, a Comissão Nacional de Ética em Pesquisa, devido a sua ligação com o tema a ser enfrentado. Adiante, será desvendada a atribuição do CNS e o alicerce desta na ordem jurídica brasileira, sob a égide da Constituição Federal de 1988. O último ponto do Capítulo III será um exame acerca da dinâmica decisória do Conselho, momento no qual se observa a ligação entre este e o Ministro da Saúde, questão também de suma importância para as conclusões finais.

No Capítulo final, chega-se a discussão para a qual os Capítulos anteriores serviram de premissa, qual seja, a atribuição normativa do CNS no tocante as pesquisas científicas envolvendo seres humanos. Desta forma, inicialmente, será abordada a Resolução 196/96, anexa, ato normativo responsável por impulsionar a discussão principal, e as disposições nela previstas. Adiante, será realizada uma breve investigação acerca da relevância de tais direitos no atual contexto histórico, o que também tem consequência nas conclusões finais deste estudo, no que se refere à necessidade de uma normatização que efetive uma proteção correspondente a tamanha pertinência. Posteriormente, serão analisadas diferentes proposições, sob o enfoque da amplificação da legalidade administrativa, acerca da Resolução 196/96 diante do Estado Democrático de Direito, quais sejam, se trata-se de um ato normativo secundum legem, praeter legem ou ainda contra legem. Por fim, será investigada se a atribuição em comento corresponde aos ditames constitucionais, principalmente no que diz respeito ao princípio democrático e aos direitos fundamentais. Dessa forma, 
após a exposição acerca da legitimidade, respeito ao princípio democrático e discricionariedade da administração pública, chega-se a sugestões finais, que, salienta-se, não tem a pretensão de esgotar ou tema ou indicar a defesa ou denuncia da atividade realizada pelo Conselho Nacional de Saúde, mas apenas fomentar a discussão, ainda irrisória. 


\section{CAPÍTULO I - ATRIBUIÇÕES NORMATIVAS DA ADMINISTRAÇÃO PÚBLICA CONSOANTE OS PRINCÍPIOS DA LEGALIDADE E DA JURIDICIDADE}

No presente Capítulo será analisada a nova concepção acerca do princípio da legalidade, consubstanciada na juridicidade administrativa. Para tanto, será realizada, inicialmente, uma investigação acerca da relevância dos princípios jurídicos para o direito administrativo e da origem do princípio da legalidade. Ademais, passa-se a um estudo acerca do conceito e dimensões do princípio da legalidade, das razões e consequências da amplificação de tal princípio.

\section{I.I Relevância dos Princípios para o Direito Administrativo}

O Direito Administrativo, desde o seu surgimento, foi norteado por princípios que lhes são próprios, já que, sendo um ramo autônomo, com regime jurídico próprio, despertou a necessidade do surgimento de regras e princípios jurídicos específicos para guiar sua atuação ${ }^{2}$. Isso foi necessário para conter os poderes administrativos e proteger os cidadãos de possíveis abusos. Ainda, a disciplina também utiliza outros princípios, não específicos do Direito Administrativo, aqueles chamados princípios gerais de direito, que seriam princípios fundamentais, aplicados de uma maneira um pouco diferente ao Direito Administrativo, no qual teremos conseqüências concretas diferenciadas.

\footnotetext{
2 "Podemos dizer que os princípios jurídicos são ideias ou intenções normativas gerais rectoras da regulação jurídica. São critérios axiológicos (expressivos de valores ético-sociais e políticos - valores ideológicos gerais, se se quiser - ou de valores mais especificamente jurídicos) que fundamentam ou informam a normação jurídica e concretas realizações do direito. Refletem, portanto, determinações valorativas da consciência jurídica geral." (ABREU, Jorge Manuel Coutinho de. Sobre os Regulamentos Administrativos e o Princípio da Legalidade. Coimbra: Almedina, 1987. p. 136-137.)
} 
A doutrina costuma classificá-los como princípios expressos e implícitos ou reconhecidos, esta última nomenclatura adotada por JOSÉ DOS SANTOS CARvalho Filho ${ }^{3}$. Segundo Celso Antônio BAndeira de Mello, a diferença entre princípios expressos e implícitos seria a de que, enquanto os primeiros encontram-se expressamente dispostos no Capítulo referente à Administração Pública na Constituição Federal de 1988, em seu artigo 37, os demais seriam aqueles que constam do texto constitucional, apesar de não estarem previstos no artigo mencionado, ou que são consequências dos princípios expressos e ainda aqueles que decorrem do próprio Estado de Direito ${ }^{4}$.

A grande questão, muito além de uma mera disposição acerca de suas possíveis classificações, é estabelecer a razão de tamanha importância dos princípios para o Direito Administrativo. O motivo é simples: não existe uma codificação para o Direito Administrativo geral, ou seja, falta uniformidade. As matérias são tratadas em leis federais, estaduais, distritais e municipais esparsas, o que gerou a necessidade de maior uniformização, necessidade esta que é suprida pelos princípios. Dessa forma, os princípios, exercendo papel unificador ao nortear a atividade administrativa, conferem segurança jurídica ao ramo do Direito, advindo daí sua importância para o Direito Administrativo. Nos dias de hoje os princípios são considerados como normas jurídicas, o que é chamado de normatividade dos princípios por PAULO BONAVIDES. O autor defende ainda a idéia de que a normativade dos princípios passou por três fases até atingir o estágio atual, do pós-positivismo. A primeira fase seria a do jusnaturalismo, na qual a sociedade possuiria valores e pretensões independentes e limitadores das normas jurídicas.Os princípios tinham caráter

\footnotetext{
${ }^{3}$ CARVAlHO FILHO, José dos Santos. Manual de Direito Administrativo. $21^{\text {a }}$ Edição. Rio de janeiro: Lumen Juris, 2009. p. 30.

${ }^{4}$ MELLO, Celso Antônio Bandeira de. Curso de Direito Administrativo. $26^{\text {a }}$ Edição. São Paulo: Malheiros, 2009. p. 95.
} 
meramente informativo, não eram encarados como norma, dessa forma, não vinculavam a atuação estatal nem serviam de alicerce para invalidação de atos normativos.

$\mathrm{Na}$ segunda fase, a chamada fase positivista, existia a idéia de que a lei contém todo o direito, proveniente do apego à objetividade científica existente na época. Seguindo algumas interpretações das obras de HANS KELSEN, defendia-se que o ordenamento jurídico seria completo, não administindo a existência de lacunas no sistema ${ }^{5}$. Dessa forma, os princípios, apesar de serem vistos como norma, teriam um caráter secundário em relação à lei. Nesse momento os princípios poderiam vincular a atuação da Administração Pública, mas essa vinculação seria sempre subsidiária à lei, ou seja, em caso de omissão legislativa, os princípios poderiam ser utilizados.

Já a terceira fase, consistente no contexto atual, foi chamada de póspositivista, trazendo, na visão de LUís ROBERTO BARROSO, "deferência relativa ao ordenamento positivo, mas nele reintroduzindo as idéias de justiça e legitimidade" ${ }^{6}$. Neste momento os princípios são encarados não só como normas jurídicas, mas também, como normas primárias ${ }^{7}$. Dessa forma, podem vincular atos e podem também ser invocados, já que possuem conteúdo autônomo. Mais que isso, hoje, tamanha sua importância, os princípios são utilizados como instrumento de controle de constitucionalidade de leis e atos normativos. O pós-positivismo defende, como já afirmado, uma aproximação entre a moral e o direito, rechaçando a idéia positivista de que a lei seria justa pelo simples fato de ser lei. Nos ideais pós-positivistas a legalidade e

\footnotetext{
${ }^{5}$ KELSEN, Hans. Teoria Pura do Direito. 6 a Ed. São Paulo: Martins Fontes, 2000. p 273-277.

${ }^{6}$ BARROSO, Luís Roberto. Interpretação e Aplicação da Constituição: Fundamentos de uma dogmática constitucional transformadora. $6^{\text {a }}$ Edição. São Paulo: Saraiva, 2004. p. 326

${ }^{7}$ BONAVIDES, Paulo. Curso de Direito Constitucional. 26a Edição. São Paulo: Malheiros., 2011. p. 259-275.
} 
moralidade são vistas como categorias distintas, no entanto, a primeira delas deve buscar adequar-se a segunda ${ }^{8}$.

Assim, a doutrina atual classifica as normas jurídicas em regras e princípios. Em linhas gerais, temos que as regras possuem caráter mais objetivo enquanto os princípios são dotados de abstração, sendo estas características justificadoras de diferenças na sua aplicação. No entanto, é importante ressaltar que não há hierarquia entre tais espécies normativas, por obediência ao princípio da unidade da Constituição, como lembrado por Luís ROBERTO BARROSO ${ }^{9}$.

Seguindo lições de RONALD DWORKIN, RAFAEL OLIVEIRA elucidou que, para o autor, a aplicação da regras se daria no plano de validade, na chamada aplicação do tudo ou nada, desta forma deveriam ser resolvidos possíveis conflitos entre essa espécie de normas jurídicas. Ou seja, uma vez em conflito, uma das normas conflitantes será considerada válida e a outra será nula na situação concreta, no que é chamado de método lógico-formal da subsunção ${ }^{10}$. Para se chegar à regra que deverá prevalecer deve se utilizar os critérios elencados por NORBERTO BOBBIO, quais sejam: o critério hierárquico, critério cronológico e o critério da especialidade ${ }^{11}$. Em linhas gerais, no

\footnotetext{
${ }^{8}$ Sobre a questão: “A superação histórica do Jusnaturalismo e o fracasso político do Positivismo abriram caminho para um conjunto amplo e ainda inacabado de reflexões acercado do Direito, sua função social e sua interpretação. O Pós-Positivismo é a designação provisória e genérica de um ideário difuso, no qual se incluem a definição das relações entre valores, princípios e regras, aspectos da chamada Nova Hermenêutica Constitucional, e a teoria dos direitos fundamentais, edificada sobre o fundamento da dignidade humana. A valorização dos princípios, sua incorporação, explícita ou implícita, pelos textos constitucionais, e o reconhecimento pela ordem jurídica de sua normatividade fazem parte desse ambiente de reaproximação entre Direito e Ética." BARROSO, Luis Roberto e BARCELlOS, Ana Paula de. O Começo da História. A nova Interpretação Constitucional e o Papel dos Princípios no Direito Brasileiro. Biblioteca Digital Fórum Administrativo - Direito Público -FA. Belo Horizonte: Fórum. Ano 4. N 37, 2004. p. 9.

9 BARROSO, Luís Roberto. Interpretação e Aplicação da Constituição: Fundamentos de uma

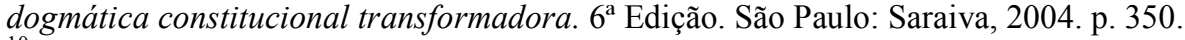

10 OLIVEIRA, Rafael Carvalho Rezende. A Constitucionalização do Direito Administrativo. O Princípio da Juridicidade, a Releitura da Legalidade Administrativa e a Legitimidade das Agências Reguladoras. Rio de Janeiro: Lumen Juris, 2009. p. 21.

11 "Como antinomia significa o encontro de duas proposições incompatíveis, que não podem ser ambas verdadeiras, e, com referência a um sistema normativo, o encontro de duas normas que não podem ser
} 
critério hierárquico a lei superior prevalece sobre a lei inferior, dessa forma, a Constituição prevalece sobre as leis e as leis prevalecem sobre os atos administrativos, por exemplo. No critério cronológico, por sua vez, a lei posterior prevalece sobre a lei anterior. Já no critério da especialidade a lei especial prevalece sobre a lei geral.

Os princípios, por sua vez, não admitem o método lógico-formal da subsunção. Possíveis conflitos entre tal espécie devem ser resolvidos com base na ponderação de valores, surgindo neste ponto a noção de que princípios são mandados de otimização, nas palavras de ROBERT ALEXY ${ }^{12}$. Nesse sentido, os princípios não admitem invalidação, mas admitem sua ponderação para que sejam aplicados da forma mais ampla que seja possível na situação específica. O que leva à limitação dos princípios pode ser outro princípio que deva também ser observado no caso analisado ou regras que representem uma exceção ao mesmo ${ }^{13}$.

É válido ainda que se recorde os ensinamentos de CANOTILHO, ao expor critérios para que se possa diferenciar regras de princípios. O primeiro desses critérios seria o grau de abstração, uma vez que os princípios possuem uma abstração elevada, enquanto as regras apresentariam abstração reduzida. $\mathrm{O}$ segundo critério seria o grau de determinabilidade, segundo o qual as regras admitiriam uma aplicação imediata, enquanto os princípios, possuindo indeterminação, careceriam das chamadas mediações caracterizadoras. $\mathrm{O}$ terceiro critério apresentado pelo autor seria o caráter de fundamentabilidade

ambas aplicadas, a eliminação do inconveniente não poderá consistir em outra coisa senão na eliminação de uma das duas normas (no caso de normas contrárias, também na eliminação das duas) [...]" (BOBBIO, Norberto. Teoria do Ordenamento Jurídico. 5a Edição. São Paulo: UNB, 1994. p. 9197)

12 Ibid. p. 22

${ }^{13}$ Sabemos que as distinções entre princípios e regras são atribuídas, pela doutrina e também pela jurisprudência brasileiras a Ronald Dworkin e a Robert Alexy. Apesar de haver semelhanças nas classificações feitas pelos dois autores, e importante destacar que o método proposto por cada um deles para lidar com tais espécies normativas, mormente os princípios, ê deveras distinta. Ao passo que Alexy lida com o a proporcionalidade, Ronald Dworkin apresenta o método da integridade. 
no sistema de fontes do direito, no qual os princípios possuem natureza estruturante. Este fato seria consequência de sua posição hierárquica, como no exemplo apresentado pelo autor dos princípios constitucionais, ou à sua fundamentabilidade dentro do sistema jurídico, exemplificado através do princípio do Estado de Direito. Outro critério seria o da proximidade da ideia de direito, segundo o qual os princípios seriam vinculantes devido à sua ligação com critérios de justiça ou na ideia de direito, enquanto as regras podem exercer função vinculativa, a despeito de um conteúdo meramente funcional. O quinto critério adotado pelo autor é o da natureza normogenética exercida pelos princípios. Isso porque, considerando que os princípios representam a base das regras jurídicas, o autor defende que exercem uma função normogenética fundamentante ${ }^{14}$.

Todo o exposto traduz a importância dos princípios nos dias atuais, para o Direito e especialmente para o Direito Administrativo. Sua violação, nas lições de CElso ANTÔNIO BANDEIRA DE MEllo, é a mais grave forma de ilegalidade, traduzindo-se em subversão de seus valores fundamentais. ${ }^{15}$ Passemos então ao exame acerca do princípio da legalidade, fundamental à atividade administrativa.

\section{I.II Algumas notas sobre a origem do Princípio da Legalidade Administrativa}

Para que seja possível analisar a atribuição normativa do Conselho Nacional de Saúde e de suas Comissões, em especial a CONEP, é

\footnotetext{
${ }^{14}$ CANOtilho, J. J. Gomes. Direito Constitucional e Teoria da Constituição. ${ }^{a}$ Edição. Coimbra: Almedina, 2003. p.1160.

15 "Violar um princípio é muito mais grave que transgredir uma norma qualquer. A desatenção ao princípio implica ofensa não apenas ao específico mandamento obrigatório, mas a todo sistema de comandos. É a mais grave forma de ilegalidade ou inconstitucionalidade, conforme o escalão do princípio atingido, porque representa insurgência contra todo o sistema, subversão de seus valores fundamentais, contumélia irremissível a seu arcabouço lógico e corrosão de sua estrutura mestra. Isto porque, com ofendê-lo, abatem-se as vigas que sustêm e alui-se toda a estrutura nelas esforçada." (MELLO, Celso Antônio Bandeira de. Curso de Direito Administrativo, Op. cit. p. 818)
} 
imprescindível que se faça uma análise do princípio da legalidade. Ainda, é necessário que se discorra brevemente acerca de suas raízes históricas e doutrinárias, para depois situá-lo no contexto atual.

Como escreve JoSÉ MANUel SÉRVUlo CORReiA ${ }^{16}$, o princípio da legalidade administrativa seria consequência do liberalismo. Seguindo esta linha de argumentação, as ambições liberais foram responsáveis pelo desenvolvimento do conceito, no cenário de busca pela ruptura com o Absolutismo, fundado este na vontade do soberano. Apoiada na doutrina de JOHN LOCKE, filósofo político, está a ideia de que seria a lei o instrumento mais eficaz para assegurar a liberdade e propriedade, valores centrais deste novo regime ${ }^{17}$.

Dessa forma, ao ingressar na sociedade política o homem teria consentido na criação de leis, sendo estas discutidas e aprovadas pelo povo, tornando-se clara a natureza democrática da chamada doutrina da soberania popular, pautadas no Contrato Social, de JEAN JACQUe RousSEAU. O filósofo defendia que a lei consistia na materialização da vontade popular e que o chamado Poder Executivo seria nada mais que uma função, já que seria o povo o real detentor do poder de Estado.

Assim surge a noção de que, com participação social para criação de uma norma jurídica geral e abstrata, a lei, os indivíduos admitiriam que parte de suas liberdades fossem restringidas em prol da coletividade, com consentimento daqueles que se obrigam. Nesse conceito residiria a primeira das raízes doutrinárias do princípio da legalidade, vislumbrando na lei a

\footnotetext{
16 CORREIA, José Manuel Sérvulo. Legalidade e Autonomia Contratual nos Contratos Administrativos. Coimbra: Livraria Almedina, 1987. p. 17-32.

17 "Uma vez que o grande objetivo do ingresso dos homens em sociedade é a fruição da propriedade em paz e segurança, e que o grande instrumento e meio disto são as leis estabelecidas nessa sociedade [...]"(LOCKE, John. Two treatsises of civil government. London: Everyman's Library, 1996, p.117241. Tradução de Cid Knipell Moreira.) Os clássicos da política.In: MELLO, Leonel Itaussu Almeida. John Locke e o individualismo liberal. In: WEFFORT, Francisco. Os clássicos da política. I. São Paulo: Ática, 13ª Ed., $12^{\mathrm{a}}$ reimpressão, 2005.p.100.)
} 
racionalidade capaz de conferir certeza, previsibilidade e justiça nas relações dos indivíduos regidos pelo contrato social.

Passa-se então ao que seria a segunda raiz histórica do princípio da legalidade segundo SÉRVULO CORREIA: o princípio separação de poderes, uma vez que teria o fito de "criar condições institucionais de respeito da esfera individual" ${ }^{18}$. Importante lembrar que o princípio foi profundamente abordado por LOCKE e MONTESQUIEU, fundados na noção de que a lei só alcançaria seu objetivo de ser imparcial e justa, caso fosse aplicada por pessoas distintas daquelas que as editou. Caso contrário, os aplicadores do direito, e nesse sentido, também seus editores, facilmente cederiam à tentação de beneficiar-se com adaptações discricionárias ${ }^{19}$. Para muitos autores, como DALMO DE ABREU DALLARI, as obras dos filósofos retromencionados foram influenciadas por ARISTÓTELES, que já acreditava ser “injusto e perigoso atribuir-se a um só indivíduo o exercício do poder" ${ }^{20}$.

Assim fica clara a necessária distinção entre legislativo e executivo, vislumbrada quando o princípio começou a ser posto em prática no período pós Revolução Francesa. Verificou-se ainda que existia uma colaboração entre os poderes, criando uma interdependência entre eles, ao invés da existência de poderes completamente independentes e excludentes. Nesse sentido pode-se visualizar o contexto atual do exercício de funções típicas e outras atípicas pelos poderes, marcado pela especialização em determinada função, mas não em seu exercício estrito. Ou seja, verifica-se a existência de um critério de preponderância de funções, não de exclusividade ${ }^{21}$.

18 CORREIA, José Manuel Sérvulo. Legalidade e Autonomia Contratual nos Contratos Administrativos, Coimbra: Livraria Almedina, 1987. p. 25.

${ }^{19}$ Ibid, p. 22.

${ }^{20}$ DALLARI, Dalmo de Abreu. Elementos de Teoria Geral do Estado. $28^{a}$ Edição, São Paulo: Saraiva, 2009.

${ }^{21}$ Sobre a diferença entre funções típicas e atípicas, segue elucidação de Carvalho Filho: "A cada um dos Poderes de Estado foi atribuída determinada função. Assim, ao Poder Legislativo foi cometida a 
Outrossim, como consequência da colaboração e harmonia entre os poderes, surgiu também o sistema de freios e contrapesos, no qual um poder é limitado por outro, assim, cada um dos poderes será também responsável por controlar os atos dos demais. Existe um controle recíproco, e, assim, com um controle funcionando internamente da máquina estatal, é possível evitar abusos de poder.

Avançando na análise da doutrina, admitida como um dos precedentes do princípio da legalidade, nota-se divergência entre o objetivo pretendido por ela nas visões de RoUSSEAU e de MONTESQUIEU. Como salientado por SÉRVULO CORREIA, ao passo que o primeiro defendia a doutrina por motivações organizatórias apenas, para o segundo a doutrina atinge seu objetivo por distribuir o poder de forma justa entre os diversos setores da sociedade. ${ }^{22} \mathrm{O}$ ponto de consenso para a doutrina seria a noção de que o princípio constitui "técnica de extrema relevância para a garantia dos direitos do Homem" 23.

Isto posto, fica claro que o princípio da legalidade surge como um dos principais vieses da Revolução Francesa de 1789, proveniente das doutrinas, retromencionadas, liberalistas e de separação de poderes. Trata-se de uma das bases fundamentais para o surgimento de um Estado pautado na lei, aquele que não intervém na propriedade ou na liberdade dos indivíduos e encontra-se limitado pela ordem jurídica, o chamado Estado de Direito. É inconteste que os

função normativa (ou legislativa); ao Executivo, a função administrativa; e, ao Judiciário, a função jurisdicional.

Entretanto, não há exclusividade no exercício das funções pelos Poderes. Há, sim, preponderância. As linhas definidoras das funções exercidas pelos Poderes têm caráter político e figuram na Constituição. Aliás, é nesse sentido que se há de entender a independência e a harmonia entre eles: se, de um lado, possuem sua própria estrutura, não se subordinando a qualquer outro, devem objetivar, ainda, os fins colimados pela Constituição.

Por essa razão é que os Poderes estatais, embora tenham suas funções normais (funções típicas), desempenham também funções que materialmente deveriam pertencer a Poder diverso (funções atípicas), sempre, é óbvio, que a Constituição o autorize." (CARVALHO FILHO, José dos Santos. Manual de Direito Administrativo. $21^{a}$ Edição. Rio de janeiro: Lumen Juris, 2009. p. 2)

${ }^{22}$ CORREIA, José Manuel Sérvulo. Op. Cit .p. 31.

23 SILVA, José Afonso da. Curso de Direito Constitucional Positivo. 27 $7^{\mathrm{a}}$ Edição. São Paulo: Malheiros, 2006. p. 109. 
pilares para o surgimento deste novo sistema institucional foram o princípio da separação de poderes, a consagração dos direitos fundamentais, através da Declaração de Direitos do Homem e do Cidadão de 1791, e o princípio da legalidade, todos decorrentes da superação do Estado Absolutista, marcado pela inexistência de limites para a atuação estatal.

Para corrente significativa da doutrina seriam também estas as bases para o surgimento do Direito Administrativo, uma vez que a limitação do Estado pela lei possibilitou que surgissem regras para regular a relação Estadocidadão. Lição esta consubstanciada nas palavras de JOSÉ DOS SANTOS CARVAlHo FILHO, quando afirma que o surgimento do Direito Administrativo só foi possível quando "o Poder criador do direito passou também a respeitá10 , 24 .

O marco do surgimento do Direito Administrativo, no entanto, seriam dois. O primeiro marco seria a edição da Lei do 28 pluviose do ano VIII (1800), na França, que estabeleceu normas reguladoras da atuação do Estado e também protetivas dos cidadãos. $\mathrm{O}$ segundo marco seria o Caso Blanco, responsável por criar normas e princípios próprios que passaram a ser aplicados a situações em que estivessem envolvidos o Estado ou pessoas que estivessem praticando atividade estatal, como delegatárias ou concessionárias ${ }^{25}$. É importante ressaltar que tal decisão foi proferida pelo Conselho de Estado,

\footnotetext{
${ }^{24}$ CARVAlho FILHO, José dos Santos. Manual de Direito Administrativo. $21^{\text {a }}$ Edição. Rio de janeiro: Lumen Juris, 2009. p. 7.

${ }^{25}$ O caso Blanco consistiu nos fatos a seguir descritos. Segundo lições de Maria Sylvia Zanella Di Pietro, trata-se de ação na qual foi julgado o atropelamento de uma criança francesa, Agnès Blanco. Ocorre que seu atropelamento foi ocasionado por um vagonete de uma empresa pertencente ao Estado, a Companhia Nacional de Manufactura de Fumo, surgindo assim um conflito de competência diante da dualidade de jurisdição existente na França. O conflito foi então solucionado com a atribuição de competência ao Conselho de Estado, já que tratava-se de um acidente ocasionado por um serviço público. A inovação do caso Blanco consiste justamente na definição da jurisdição administrativa em face de litígio decorrente de responsabilidade pelo serviço público e também do desenvolvimento de princípios autônomos, segundo os quais a questão seria resolvida. (DI PIETRO, Maria Sylvia Zanella. Direito Administrativo. 18 Edição. São Paulo: Atlas, 2005. p. 27)
} 
órgão de jurisdição administrativa, e representou uma evolução no Direito Administrativo, consoante opinião majoritária da doutrina. Ainda que seja a França um país de tradição romano-germânica, com apego às compilações de leis, foi a jurisprudência a responsável por consagrar o Direito Administrativo como ramo autônomo do Direito ${ }^{26}$.

Posição interessante de Gustavo BInENBOJM, partindo das lições do autor português PAULO OTERO, na qual defende que a construção do Direito Administrativo ocorreu com a manutenção do Regime Absolutista, não com sua superação, uma vez que não houve milagre, mas tão só uma espécie de disfarce causado pelo contexto histórico. Nesse sentido, o desenvolvimento do Direito Administrativo teria sido responsável por perpetuar a inexistência de controle da Administração Pública por parte da sociedade. ${ }^{27}$ Logo, a ideia de que o Executivo estaria submisso à lei, e em última escala, ao próprio povo, já se iniciou viciada, uma vez que a própria noção de que o Executivo deveria estar submetido a regras distintas daquelas a que estariam submetidos os particulares, já partiu da própria Administração Pública, pelo Conselho de Estado, no caso Blanco já abordado. Situação esta que não se coaduna com os postulados do Estado de Direito ${ }^{28}$, pois ao editar suas próprias normas e julgar suas próprias causas, a Administração destrói qualquer cunho garantístico dos

\footnotetext{
${ }^{26}$ Binenbojm, Gustavo. Uma teoria do Direito Administrativo: Direitos Fundamentais, Democracia e Constitucionalização. 2a edição. Rio de Janeiro: Renovar, 2008. p. 11.

${ }^{27}$ Ibid. p. 11.

${ }^{28}$ Existem diversas conceituações e concepções de Estado Democrático de Direito. Nesta monografia, adotaremos a exposta por JORGE REIS NOVAIS. Segundo o jurista português, ha uma concepção formal do estado Democrático de Direito, centrada nas formas e nos mecanismos jurídicos de contenção, limitação, participação e fiscalização do e no poder estatal, como a separação das funções estatais, os devidos processos legislativos, judiciários e administrativos, os mecanismos de participação política e de chegada aos cargos públicos e políticos e assim sucessivamente. Ha, também, uma concepção material, na qual, além dos elementos formais, soma-se um grupo de elementos materiais, centrados nos direitos fundamentais, ai incluídos os civis, políticos e sociais. NOVAIS, Jorge Reis. Contributo para uma teoria do Estado de Direito. Coimbra: Almedina, 2006.
} 
direitos individuais. Em última análise, este fato não corresponde, materialmente falando, a uma limitação e representa apenas a continuidade de um Estado arbitrário. Por isso afirma o autor que a evolução de tal ramo do direito deve ser vista como uma "sucessão de impulsos contraditórios, produto da tensão dialética entre a lógica da autoridade e a lógica da liberdade" ${ }^{29}$.

\section{I.III Princípio da Legalidade: conceito e dimensões do princípio em tela}

O princípio da legalidade surgiu da ideia de um Estado baseado na lei, ou seja, o Estado só pode exercer determinada atividade caso ela esteja previamente habilitada por lei. É importante salientar, no entanto, que tal conceito é deveras variável, não sendo apresentado de maneira uniforme nos ordenamentos jurídicos. O consenso reside, na verdade, na ideia de que o conceito irá variar de acordo com a ordem jurídica na qual esteja inserido, como explicitou SÉRVULO CORREIA ao afirmar que a alteração parcial do significado do princípio ocorre pela modificação na sua posição funcional, causada pela evolução da estrutura constitucional ${ }^{30}$. Ou seja, é a estrutura constitucional de cada ordenamento que irá determinar o significado do princípio naquele contexto jurídico específico.

De acordo com posição significativa da doutrina administrativista, o princípio da legalidade comportaria duas dimensões: preferência da lei e reserva de lei. Segundo a primeira dimensão, da primazia de lei ou compatibilidade, a lei ocuparia posição hierarquicamente superior aos demais atos normativos, exceto, logicamente, a Constituição Federal. Nesse sentido, também compreendido como vinculação negativa da Administração Pública, a lei teria uma função limitadora, ou seja, caso existisse uma lei, a

\footnotetext{
${ }^{29}$ Ibid. p. 18.

30 CORREIA, José Manuel Sérvulo. Legalidade e Autonomia Contratual nos Contratos Administrativos. Coimbra: Livraria Almedina, 1987. p. 34.
} 
Administração deveria se guiar por tal lei. No entanto, caso não existisse lei, o Administrador poderia exercer suas atividades livremente. Nessa hipótese, sobrevindo uma lei sobre a atividade, o Administrador teria que se adequar, já que a lei possui preferência, daí a noção de limitação. Já a segunda dimensão, chamada de reserva de lei, consiste na ideia de que o Administrador deve basear-se nas leis e não somente não contrariá-las, assim, indo além da mera limitação, a segunda dimensão exige a habilitação por lei. Esta concepção prevalece nas lições de HELY LOPES MEIRELLES, responsável, no Brasil, por difundir uma distinção entre a noção de legalidade para o particular e para o Administrador $^{31}$. Enquanto o primeiro pode atuar livremente, a não ser que haja uma limitação expressa em lei, o Administrador só poderá atuar caso exista uma lei, e pautado nos limites traçados por esta.

A explicação para a afirmativa é a de que enquanto o particular tem como regra geral sua própria autonomia, o Estado, nada mais que uma máquina criada com o objetivo de concretizar os Direitos Fundamentais e realizar o interesse da sociedade, tem como condição de suas atividades a subordinação ao ordenamento jurídico ${ }^{32}$. Razão disso é a ideia, não obstante sua atual revisão, de que tais interesses sociais, os chamados interesses públicos ${ }^{33}$, são indisponíveis, portanto, ao Estado, mero administrador e não proprietário, cabe apenas curá-los, seguindo os preceitos estabelecidos em lei. Quando se confere

\footnotetext{
31 "Na Administração não há liberdade nem vontade pessoal. Enquanto na administração particular é lícito fazer tudo que a lei não proíbe, na Administração Pública só é permitido fazer o que a lei autoriza." (MEIRELLES, Hely Lopes. Direito Administrativo brasileiro. $18^{\text {a }}$ edição. São Paulo: Malheiros, 1993. p. 82-83.).

${ }^{32}$ Binenbojm, Gustavo. Uma teoria do Direito Administrativo: Direitos Fundamentais, Democracia e Constitucionalização. 2a edição. Rio de Janeiro: Renovar, 2008. p. 140.

33 "É que, na verdade, o interesse público, o interesse do todo, do conjunto social, nada mais é que a dimensão pública dos interesses individuais, ou seja, dos interesses de cada indivíduo enquanto partícipe da Sociedade (entificada juridicamente no Estado) [...]" (MELLO, Celso Antônio Bandeira

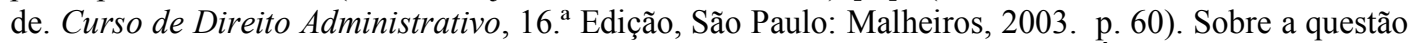
deve-se ter em mente sua atual revisão, proposta por autores como Humberto Àvila, que defendem a ponderação entre direito público e privado no caso concreto, ao invés da existência de um "princípio abstrato de supremacia" (ÁVILA, Humberto. Repensando o "Princípio do Interesse Público sobre o Particular”. Revista Diálogo Jurídico, Salvador, CAJ - Centro de Atualização Jurídica, v. I, no 7 , outubro, 2001. Disponível em: www.direitopublico.com.br. Acesso em 28 de setembro de 2012.
} 
poderes à Administração, devemos ter em mente que a esfera de liberdade dos indivíduos foi restringida, sendo, portanto, essencial que o ordenamento jurídico, máxime o legislador democraticamente eleito, seja o responsável por tal limitação, como forma de proteção à liberdade e aos Direitos Fundamentais dos indivíduos. Assim, os poderes da Administração são diretamente dependentes do ordenamento jurídico-legal, que representa seu fundamento de validade. Dessa forma, somente pautado em previsão legal podemos falar na real existência de determinado poder da Administração ${ }^{34}$.

Impossível fugir ainda às lições de HANS KELSEN, que defendeu a ideia de escalas na produção jurídica, representando consequência direta da indeterminação das normas. Para o autor, os atos normativos não são dotados de completude, cabendo, desta forma, aos atos imediatamente inferiores sua concretização de forma gradual, na chamada teoria da atribuição normativa precedente. Nesse sentido, a Administração Pública só poderia atuar caso houvesse um ato normativo hierarquicamente superior, a lei, que o fundamentasse ${ }^{35}$.

É importante ressaltar que tais dimensões são provenientes dos ensinamentos de CHARLES EISENMANN, responsável por uma aprofundada investigação acerca do princípio. Para o autor, o princípio se refere à relação entre dois objetos. O primeiro deles seria a conduta da Administração Pública, indo além dos meros atos administrativos, uma vez que, ao falarmos em conduta estamos tratando também de possíveis omissões dos órgãos administrativos. Já o segundo objeto seria justamente o sentido da palavra

\footnotetext{
${ }^{34}$ A tradução do pensar tradicional sobre o princípio da legalidade pode ser percebida no seguinte excerto: "Não custa lembrar, por último, que, na teoria do Estado moderno, há duas funções estatais básicas: a de criar a lei (legislação) e a de executar a lei (administração e jurisdição). Esta última pressupõe o exercício da primeira, de modo que só se pode conceber a atividade administrativa diante dos parâmetros já instituídos pela atividade legiferante. Por isso é que administrar é função subjacente à de legislar. O princípio da legalidade denota exatamente essa relação: só é legítima a atividade do administrador público se estiver condizente com o disposto na lei" (CARVALHO FILHO, José dos Santos.Op. Cit.p. 19.)

${ }^{35}$ KELSEN, Hans. Op. Cit. p. 246-255.
} 
"legalidade", ou seja, de quais atos normativos estaríamos nos referindo ao utilizar a expressão "legalidade". Para posição tradicional da doutrina, estaríamos nos referindo apenas ao produto do processo legislativo, ou seja, às leis emanadas do Poder Legislativo. Já para uma visão mais ampliativa a expressão "legalidade" diria respeito a todo um bloco de normas, e não somente às leis. Nesta visão, esse conjunto de normas seria variável, para uma parte da doutrina diria respeito às leis, regulamentos, tratados e costumes. Para outros, poderíamos incluir ainda atos e contratos administrativos, representando uma visão que classifica como "legalidade" todo o "direito vigente". EISENMANN adota a visão tradicional, vislumbrando o princípio da legalidade como fruto da relação entre a conduta administrativa e as leis, normas advindas do Poder Legislativo apenas. O autor adota tal compreensão devido a questões históricas, da própria origem do princípio, pois defende que a concepção originária do princípio foi deveras alterada até se chegar à noções tão ampliativas. $O$ autor defende ainda a posição tradicional acerca da expressão "legalidade" devido a questões teóricas, uma vez que o objetivo do princípio é estabelecer normas que teriam valor superior à conduta administrativa e, por isso, a limitaria. Nesse sentido, o autor acreditava ser impensável que fosse possível estabelecer que regulamentos, atos próprios da Administração, sejam superiores ao restante dos atos praticados pelo Poder Executivo ${ }^{36}$. Após estabelecer as razões de sua opção por uma visão tradicional do conceito de princípio da legalidade, consubstanciado na relação entre os atos administrativos e as leis, o autor inicia uma análise acerca das formas em que se dará tal relação. Tratando-se de atos administrativos, poderíamos visualizar uma noção mínima e outra máxima, ambas retromencionadas, de sua relação com a legalidade. A noção mínima,

\footnotetext{
${ }^{36}$ Ideia que não é seguida por autores como Carvalho Filho, ao considerar a existência de atos regulamentares de $1^{\circ}$ e $2^{\circ}$ grau, questão que será abordada posteriormente. Sobre a mesma, ver: CARVALHO FILHO, José dos Santos. Op. cit. p. 57-58.
} 
representando a liberdade administrativa, seria a compatibilidade à lei, ou seja, que a Administração não pode contrariar a lei caso ela exista. Já a noção máxima, representando uma restrição, seria a conformidade com a lei, ou a chamada vinculação positiva à lei, dessa forma, toda a atividade administrativa deveria estar pautada em lei prévia. Para o autor, a noção de compatibilidade é mais abrangente que a de conformidade e ainda, a primeira estaria incluída na segunda ${ }^{37}$.

A partir de gradações acerca das noções máxima e mínima, o autor propôs quatro leituras possíveis acerca do princípio. A primeira delas seria a já vista, vinculação negativa à lei ou a não-contrariedade. A segunda concepção seria a, também já vista, necessidade de habilitação por lei. Contudo, nesta segunda leitura de EISENMANN, bastaria tão somente a atribuição da competência à Administração, ou seja, só seria exigida uma habilitação formal de competência, não de conteúdo. Adiante, na terceira visão do princípio, a habilitação por lei deveria ir além, pois o conteúdo do ato a ser praticado deveria também estar predeterminado pela lei. A quarta e última concepção proposta pelo autor defende uma Administração Pública totalmente vinculada à lei, não lhe sendo atribuída qualquer margem de decisão, uma vez que seria a lei formal a responsável por determinar todo o conteúdo dos atos a serem praticados e ainda obrigar a sua prática. Para sintetizar, toma-se de empréstimo a esquematização das leituras possíveis acerca do princípio da legalidade proposta por EISENMANN, formulada por ALEXANDRE SANTOS DE ARAGÃO ${ }^{38}$ :

\footnotetext{
37 "O caráter de conformidade inclui em si mesmo o de compatibilidade: o objeto conforme é, por essência, compatível. Há mais: quando a conformidade é prescrita, apenas o objeto conforme é compatível com a norma que prescreve e traça o modelo: neste caso, confundem-se conformidade e compatibilidade.

Mas a recíproca não é verdadeira: o caráter de compatibilidade não inclui de forma alguma o de conformidade, é distinto, e suscetível de uma existência autônoma e isolada." (EISENMANN, Charles. O Direito Administrativo e o Princípio da Legalidade. In Revista de Direito Administrativo, v. 56. p. 57)

${ }^{38}$ ARAGÃO, Alexandre Santos de. A Concepção Pós-Positivista do Princípio da Legalidade, in Revista de Direito Administrativo, v. 256.
} 
1. A primeira delas seria a noção de mera não-contrariedade à lei, existindo liberdade em hipótese de vácuo legislativo.

2. A segunda concepção prioriza uma habilitação formal da competência para atuação da administração, estando ela proibida de atuar caso não exista lei prévia habilitadora.

3. A terceira possível forma de se vislumbrar o princípio da legalidade, seria a exigência de uma norma prévia não somente habilitadora, mas que determine o conteúdo da atividade administrativa.

4. A quarta leitura determina que a lei prévia deve ordenar a prática de determinada atividade, não apenas estabelecer uma atuação facultativa, e esgotar o contéudo de tal atividade. Nessa visão não há qualquer espaço para a descricionariedade administrativa.

Tais propostas trazem à tona uma série de críticas e representam uma escala de aumento da contenção da discricionariedade do Executivo. A primeira concepção, deveras liberal, não se legitima perante o Estado de Direito, consoante a lição de AlEXANDre SANTOS DE ARAGÃo, ao defender que no choque entre a liberdade de atuação da Administração Pública e a dos indivíduos, tal compreensão, ao igualá-las, reduz excessiva e inadmissivelmente a autonomia dos indivídios, devido à imperatividade dos atos da Administração ${ }^{39}$. A terceira e quarta leituras, que impedem qualquer esfera decisória, não seriam compatíveis com o atual cenário de atuação

\footnotetext{
${ }^{39}$ ARAGÃo, Alexandre Santos de. A Concepção Pós-Positivista do Principio da Legalidade, in Revista de Direito Administrativo, v. 256.
} 
Administrativa, um cenário de ativismo, que não se amoldaria a tamanho engessamento. Conforme o autor, seria necessário atentar para o fato de a Administração Pública atual ter uma função além de mera executora da lei, e as limitações exacerbadas podem até mesmo dificultar a concretização do espírito da lei, da sua real finalidade, qual seja, os Direitos Fundamentais e os interesses público e coletivos. A posição mais adequada, segundo ODETE MEDAUAR, seria a segunda, que defende a necessidade de habilitação da competência por lei, já que possibilitaria a tomada de decisões pela Administração Pública, estando estas, logicamente, justificadas por uma disposição em lei ${ }^{40}$.

Retornando à posição predominante da doutrina, que distingue no princípio da legalidade as idéias de não contrariedade e reserva de lei, e tratando-se desta última poderiam ser verificadas diversas espécies na categoria, uma vez que a variação é proveniente da intensidade de normatização pela lei. Para SÉRVULO CORREIA, o princípio da conformidade pode ser entendido como legalidade formal e outra substancial. Na legalidade formal, a lei seria responsável por definir mínimos padrões para a atividade administrativa no que são chamadas de regras de procedimento, atribuindo a competência e outras regras de forma. Já na legalidade material ou substancial, as chamadas regras de fundamento, a lei já estebelece o fundamento e o conteúdo da atividade a ser praticada pela Administração Pública, seja de forma total ou parcial.

Existem ainda outras concepções adotadas acerca do princípio. A primeira destas distinções seria a existência de uma reserva legal relativa ou absoluta, que se baseia, nas palavras de BINENBOJM, no "grau de densificação normativa exigida ao encarregado da função legislativa, que dará ao aplicador maior ou menor espaço de conformação" ${ }^{41}$. Na primeira, o assunto deveria ser tratado

\footnotetext{
${ }^{40}$ MEDAUAR, Odete. Direito Administrativo Moderno. $7^{\text {a }}$ Edição. São Paulo: RT, 2003. p. 137.

${ }^{41}$ BinenBoJM, Gustavo. Op. cit. p. 148.
} 
na lei, mas esta estabeleceria apenas critério mínimos, não precisaria esgotar a atividade a ser regulada. Nesse caso a lei trataria de maneira abrangente, deixando espaço para atuação regulamentar do administrador e representando tão somente a regra geral, na qual são fixados os standards mínimos, que servirão de limite à atividade administrativa. $\mathrm{Na}$ reserva legal absoluta, a lei deveria tratar de maneira exaustiva sobre a matéria, não havendo espaço para liberalidade do administrador, a não ser executar o comando da lei. Assim, há um obstáculo a qualquer intromissão regulamentadora da Administração Pública, no tocante a tais matérias, principalmente tratando-se de limitações a direitos fundamentais, uma vez que a lei deveria esgotar todo o conteúdo da matéria.

Para alguns autores, tais espécies seriam equivalentes à concepção de SÉRVUlo CORREIA, no entanto, para AleXAndre SANTOS DE AragÃo, as reservas relativa e absoluta propostas se encontrariam no âmbito da legalidade material. Nesse sentido, seria uma reserva relativa quando parte do conteúdo estiver disposto em lei, já a reserva absoluta seria encontrada quando a matéria estivesse esgotada em lei.

As chamadas legalidade formal e substancial geram críticas por parte da doutrina que não podem ser esquecidas. A primeira delas, em relação à legalidade formal, afirma que ou a lei ou o próprio ordenamento jurídico sempre irão condicionar os atos a serem praticados pela Administração Pública, dessa forma, é inconcebível uma legalidade estritamente formal. Já a legalidade substancial recebeu críticas de autores como EISENMANN e CANOTILHO, para quem não seria razoável crer numa reserva absoluta, uma vez que todo regulamento possui, por menor que seja, alguma vertente inovadora e, caso não tivesse, seria inútil para a ordem jurídica ${ }^{42}$.

\footnotetext{
42 " 1 ' - A conformidade do fundamento dos atos a uma regulamentação legislativa não é, de todo, regra absoluta, nem mesmo apenas princípio geral: A exigência não se aplica, nem aos atos materiais, nem aos atos jurídicos regulamentares; vale somente, como regra geral, para as normas especiais-
} 
Existiria também para GILMAR MENDES a concepção de uma reserva legal simples ou qualificada. De acordo com a reserva legal simples o legislador apenas aborda a hipótese, sem, no entanto, estabelecer maiores condicionamentos ou qualificações sobre a prática do ato. Já na reserva qualificada, o texto da Carta Magna será responsável por, além de exigir que determinada matéria seja tratada em lei, estabelecer certos requisitos a serem cumpridos para o exercício da atividade de acordo com o ordenamento jurídico ${ }^{43}$. Assim, a Constituição seria responsável por estabelecer também os meios a serem utilizados para que se alcancem os fins almejados, estes também definidos em no texto constitucional. O que se visualiza é hipótese de dupla vinculação, uma vez que o legislador e também o administrador estarão vinculados ao estabelecido na Lei Maior ${ }^{44}$.

A última das concepções da reserva legal retromencionada seria a de reserva formal e material, categoria distinta daquela formulada por SÉRVULO CORREIA, uma vez que, nesta categoria, a reserva legal formal consiste na determinação que certo conteúdo só poderia ser tratado por lei formal, produto do processo legislativo. Já na reserva legal material, o conteúdo poderia ser abordado por qualquer espécie normativa e não somente pela lei em sentido estrito, bastando portanto, um ato materialmente normativo com força de lei. É importante salientar, no entanto, que é imprescindível que tal ato normativo possua força de lei, devendo, portanto, enquadrar-se em uma das hipóteses

individuais ou particulares- dos atos unilaterais. [...]" (EISENMANN, Charles. $O$ Direito Administrativo e o Princípio da Legalidade. In Revista de Direito Administrativo, v. 56. p. 66). E ainda: "Rigorosamente, todas as reservas são relativas porque deixam aos órgãos concretizadores (administrativos ou jurisdicionais) uma margem maior ou menor de intervenção" (CANOTILHO, J. J. Gomes. Op. cit. p.728)

${ }^{43}$ MENDES, Gilmar Ferreira; COELHO, Inocêncio Mártires; BRANCO, Paulo Gustavo Gonet. Curso

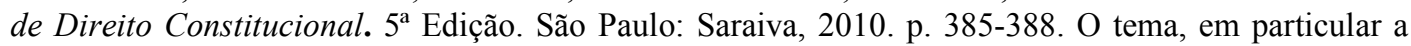
reserva qualificada, assim denominada pelo autor, pode ser considerada um avanço em relação à chamada juridicidade administrativa, que será abordada a seguir.

44 "Cuida-se aqui, portanto, de uma vinculação constitucional do legislador, tanto de forma (reserva de lei), como de conteúdo (definição prévia dos meios e fins)" (BINENBOJM, Gustavo. Op. cit. p. 151) 
previstas no artigo 59, incisos II a V da Constituição Federal. Nesse sentido, atos sem força de lei, ainda que materialmente normativos, não se enquadrariam na reserva de lei mencionada.

Por fim, deve-se ter em mente que o ordenamento jurídico brasileiro comporta as duas acepções tradicionais do princípio da legalidade: a concepção de compatibilidade ou vinculação negativa à lei e de conformidade ou vinculação positiva à lei. Com isto em mente, passemos agora às razões do desenvolvimento de uma releitura do princípio abordado.

\section{I.IV Da legalidade à juridicidade}

A partir da investigação das dimensões do princípio da legalidade é preciso passar a uma análise da latente desvalorização da lei, responsável por releituras acerca do princípio. Para que isso seja possível, é necessário que rememoremos às idéias da fase pós-positivista.

O pós-positivismo, cujas notas básicas foram brevemente sumariadas páginas atrás, foi marcado por uma mudança de paradigma, no qual os princípios passaram a ser reconhecidos como normar jurídicas. Mais que isso, no período chamado de neocostitucionalismo, sustenta-se uma valorização da força cogente das Constituições, que não mais são vistas em sua vertente meramente admonitória ${ }^{45}$. Para Luís ROBERTO BARROSO, o neoconstitucionalismo representa modificações profundas no direito constitucional e no Estado como um todo, consequência de três marcos: histórico, teórico e filosófico. O marco histórico seria justamente a mudança do

\footnotetext{
45 "A idéia de constitucionalização do Direito aqui explorada está associada a um efeito expansivo das normas constitucionais, cujo conteúdo material e axiológico se irradia, com força normativa, por todo o ordenamento jurídico. Os valores, os fins públicos e os comportamentos contemplados nos princípios e regras da Constituição passam a condicionar a validade e o sentido de todas as normas do direito infraconstitucional. Como intuitivo, a constitucionalização repercute sobre a atuação dos três poderes, inclusive e notadamente nas suas relações com os particulares" (BARROSO, Luís Roberto. Neoconstitucionalismo e Constitucionalização do Direito (o triunfo tardio do Direito Constitucional no Brasil). Revista de Direito Administrativo no 240, 2005, p. 12/13)
} 
Estado Absolutista para o Estado de Direito no final do Século XX, analisado anteriormente. O marco teórico seriam mudanças como a concepção da força cogente da Constituição e o surgimento de uma nova dogmática de interpretação constitucional, esta última responsável por permitir uma adequação das Constituições à realidade fática. Já o marco filosófico seria, a também já abordada, terceira fase da normatividade dos princípios, a fase póspositivista $^{46}$.

Um dos fatores comumente associados ao pós-positivismo e ao neoconstitucionalismo é chamado de crise da lei, consistente numa desvalorização do produto do processo legislativo. GUSTAVO BINENBOJM aponta algumas razões da crise $d a$ lei, além do próprio pós-positivismo, abordadas a seguir.

A primeira destas razões, apontadas por BINENBOJM, seria a inflação legislativa, responsável por escancarar a falta de efetividade de todo este arcabouço normativo, o que causou o desprestígio da lei perante a sociedade. A crença de que a lei seria o instrumento capaz de resolver qualquer mazela social levou a um cenário de produção normativa desenfreada, que se mostrou incapaz de resolver de fato todos os problemas existentes na sociedade, ocasionando o desprestígio da lei ${ }^{47}$.

A segunda razão seria a constatação de que a lei, pelo simples fato de ser lei, nem sempre é justa. Isso foi corroborado pelas barbáries ocorridas na história da humanidade que estiveram devidamente fundamentadas em lei. Sobre essa questão, é necessário que se recorde que a doutrina positivista

\footnotetext{
${ }^{46}$ Ibid. p. 8.

47 "O excesso de lei é uma realidade em todas as nações civilizadas, notadamente nos países de tradição romano-germânica. $\mathrm{O}$ mito positivista de completude do ordenamento jurídico, aliado ao aumento significativo das funções do Estado social, inspirou os parlamentos a tratarem de qualquer assunto, sendo corolário deste movimento a noção (muito evidente no senso comum) de que a lei seria apta a resolver todos os problemas sociais. Banalizou-se a lei, o que fez com que se esvaziasse o sentimento de respeito que se lhe nutriu no período iluminista." (BINENBOJM, Gustavo. Op. cit. p. 128)
} 
tradicional, tal como lida por BINENBOJM, principalmente as lições de KELSEN, marcante no positivismo normativista, já trazia a noção da busca pela validade das normas, e não claramente pela justiça. O autor defendia que a validade de uma norma era justamente estar pautada em outra hierarquicamente superior, em um escalonamento piramidal no qual a Constituição está posicionada em seu topo ${ }^{48}$.

A fundamentação de atos administrativos por normas infra-legais seria mais uma razão desta crise da legalidade. Isso porque tais normas correspondem à celeridade e tecnicismo que a atualidade muitas vezes requer, além de estarem pautados em espaço concedido pela legislação e, até mesmo, pela Constituição Federal. Nisso consiste a chamada deslegalização, ou seja, fenômeno através do qual o legislador transfere à Administração Pública a normatização de determinadas matérias. Estre instrumento, considerado espécie de delegação legislativa, a ser abordada posteriormente, demonstra-se capaz de legitimar o combate ao aumento exagerado do número de leis vigentes que acabam gerando insegurança e confusão nos jurisdicionados, segundo Diogo MoREIRA Neto ${ }^{49}$. Através da deslegalização, é até mesmo possível que um regulamento altere uma lei formal, caso exista outra lei formal, posterior, que o autorize. Contudo, é essencial para que o rebaixamento do status normativo de determinadas matérias seja legítimo que a lei

\footnotetext{
48 "O sistema de normas que se apresenta como uma ordem jurídica tem essencialmente um caráter dinâmico. Uma norma jurídica não vale porque tem um determinado conteúdo, quer dizer, porque o seu conteúdo pode ser deduzido pela vida de um raciocínio lógico do de uma norma fundamental pressuposta, mas porque é criada por uma forma determinada - em última análise por uma forma fixada por uma norma fundamental pressuposta. Por isso, e somente por isso, pertence ela à ordem jurídica cujas normas são criadas de conformidade com esta norma fundamental." (KELSEN, Hans. Op. Cit. p. 221.)

${ }^{49}$ Segundo o autor, a desligificação consistiria na "retirada, pelo próprio legislador, de certas matérias, do domínio da lei (domaine de la loi) passando-as ao domínio do regulamento (domaine de l'ordonnance)" MOREIRA NETO, Diogo de Figueiredo. Mutações do Direito Administrativo. Rio de Janeiro:

Renovar, 2000.

p. 166.
} 
estabeleça, obrigatoriamente, princípios inteligíveis a serem seguidos pela Administração Pública ${ }^{50}$.

Sobre a questão é importante lembrar ainda das lições de CANOTILHO, quando afirma que o limite à deslegalização consiste justamente naquelas matérias, previstas na Carta Magna, de reserva absoluta à lei ${ }^{51}$. A razão para isso é que a lei habilitadora, apesar de estipular os preceitos a serem seguidos pela Administração Pública, não adentra na normatização da matéria, assim, se matérias constitucionalmente reservadas à lei fossem objeto de deslegificação, estaríamos diante de manifesta inconstitucionalidade. Ademais, tratando-se de matérias atingidas pelo fenômeno da deslegificação, é defeso ao Poder Executivo usurpar a competência do Legislativo. Isso porque a qualquer momento o órgão legiferante pode alterar e, até mesmo, revogar a lei habilitadora, retomando desta forma a função de normatizar a matéria em questão.

Outra razão apontada pelo autor para a chamada crise da lei seria o controle do Poder Executivo sobre o processo Legislativo, controle este exercido de três formas distintas. A primeira delas seriam as reservas de iniciativas legislativas, a segunda seria a possibilidade de trancamento de pauta das deliberações no Congresso e a terceira seria a formação de sólidas bases no parlamento $^{52}$. O que se verifica então é uma realidade na qual o Legislativo não possui espaço para atuar de forma independente e o Executivo não possui a atribuição normativa que o contexto exige ${ }^{53}$.

\footnotetext{
${ }_{50}^{50}$ Adiante, no Capítulo IV, será abordada a temática dos princípios inteligíveis.

51 "Sempre que exista uma reserva material-constitucional de lei, a lei ou o decreto-lei (e, eventualmente, também, decreto legislativo regional) não poderão limitar-se a entregar aos regulamentos a disciplina jurídica da matéria constitucionalmente reservada à lei (Ac TC 641/95, DR, I, 26-10-95)." (CANOTILHO, J. J. Gomes. Op. cit. p. 841)

${ }^{52}$ Acerca das reservas de iniciativa legislativa ao Executivo, ver art. $61, \S 1^{\circ}$ e art. 63 da Constituição Federal. Quanto à viabilidade para trancamento das pautas do Congresso, ver art. $64, \S \S 1^{\circ}$ e $2^{\circ}$ e art. $62, \S 6^{\circ}$, também da Carta Magna.

${ }^{53}$ BINENBOJM, Gustavo. Op. cit. p. 134.
} 
O fio condutor decisivo da superação deste paradigma teria sido justamente a constitucionalização do direito administrativo. Para o autor, a adoção do sistema dos direitos fundamentais e do sistema democrático promoveu uma alteração no papel exercido pelas Constituições nos ordenamentos jurídicos. Hoje, é a própria Constituição a diretriz normativa legitimadora, ou seja, para que a atuação administrativa, de particulares ou mesmo legislativa possa ser considerada válida, essa atuação tem que estar de acordo com a Constituição Federal. Segundo BINENBOJM, deve-se retornar, para melhor entendimento, à ideia de KELSEN de que Constituição Federal é a lei fundamental, posicionada no topo do ordenamento, e assim, representando a norma mais importante do ordenamento, deve ser responsável por condicionar a validade não só do ordenamento como um todo, mas também das atuações concretas do Estado ou de particulares, indistintivamente. Alcançamos então a noção de filtragem constitucional, assim denominado por PAULO RICARDO SCHIER, segundo o qual todo o ordenamento deve passar por uma releitura tomando como base a Constituição ${ }^{54}$. Para o autor, a filtragem constitucional tem como pressuposto a preeminência normativa da Constituição, não mais desprovida de força cogente ${ }^{55}$.

Dessa forma, a legalidade passa por um período de releitura, uma vez que não seria mais possível conceber a ideia da lei como protagonista do ordenamento jurídico, marcante no positivismo. Durante tal período, era a lei a responsável por condicionar a validade das atividades administrativas, fruto do culto exagerado à lei, noção que teria sido superada no pós-positivismo. Com o

\footnotetext{
54 “(...) denota a idéia de um processo em que toda a ordem jurídica, sob a perspectiva formal e material, e assim os seus procedimentos e valores, devem passar sempre e necessariamente pelo filtro axiológico da Constituição Federal, impondo, a cada momento de aplicação do Direito, uma releitura e atualização de suas normas." (SCHIER, Paulo Ricardo. Filtragem Constitucional : construindo uma nova dogmática jurídica. Porto Alegre: Sergio Antonio Fabris, 1999. p. 104).

55 SCHIER, Paulo Ricardo. Novos Desafios da Filtragem Constitucional no Momento do Neoconstitucionalismo. In Revista Eletrõnica de Direito do Estado, 2005, n. 4.
} 
surgimento do pós-positivismo, os princípios ganham importância, passando a ter normatividade primária, fruto da tentativa, mencionada anteriormente, de aproximar o direito à moral. Neste novo momento, a legalidade caminha junto a outros princípios, não exercendo mais a figura central do ordenamento jurídico, como afirmado por CANOTILHO: "a reserva vertical da lei foi substituída por uma reserva vertical da Constituição" ${ }^{56}$. Em outras palavras, a legalidade administrativa estaria inserida na chamada juridicidade, representando um de seus princípios internos, não o único. Nesse sentido, o princípio da legalidade não é mais o único alicerce possível das atividades administrativas, uma vez que estas podem estar pautadas, nesta nova concepção, em referências e princípios, sendo estes expressos ou não, da Carta Magna. A Juridicidade administrativa, assim denominada por MERKL, representa desta forma, uma ideia mais ampla do princípio da legalidade, pois o ordenamento jurídico como um todo passa a ser o novo alicerce das atividades administrativas ${ }^{57}$.

Nesse sentido, AleXandre Santos De ARAgÃo defendeu a chamada concepção pós-positivista do princípio da legalidade, no qual cabe à lei estabelecer princípios e valores mínimos a serem observados pela Administração Pública, os chamados standards. Assim, a atividade administrativa estaria condicionada a um bloco de legalidade, como defendido por HAURIOU, representando este uma consolidação de tais valores e princípios do ordenamento jurídico, e não mais somente à lei ${ }^{58}$. A consequência desta

\footnotetext{
${ }^{56}$ CANOTILHO, J. J. Gomes.Op. cit.. p. 840.

57 "É necessário, por fim, entender o princípio da legalidade em seu sentido amplo, ou como princípio da juridicidade, como o denominou Merk1, ou seja, não apenas à lei formal, mas a todo o Direito" (MOREIRA NETO, Diogo de Figueiredo. Curso de Direito Administrativo: parte introdutória, parte geral e parte especial, $14^{\mathrm{a}}$ Ed. Rio de Janeiro: Forense, 2005. p. 82).

${ }_{58}$ É necessário salientar, acerca deste ponto, que a concepção de bloco da legalidade de Alexandre Santos de Aragão diverge daquela pensada inicialmente por Hauriou, Como salientado por Rafael Oliveira (OLIVEIRA, Rafael Carvalho Rezende. Op. Cit. p. 74-75), o bloco de legalidade de Alexandre Santos de Aragão inclui não somente atos normativos, mas também princípios, valores e
} 
afirmação, para o autor, seria a de que a Administração Pública estaria submetida a uma limitação maior, já que não mais somente à lei mas à todo o bloco de legalidade e, ao mesmo tempo, veria ampliada sua esfera de atividades, já que poderia atuar caso valores e princípios da ordem jurídica assim exigissem e não houvesse lei infra-constitucional autorizadora 59 .

É importante salientar que a doutrina diverge acerca dos limites a serem aplicados à chamada juridicidade. Isso porque parte da doutrina não admite que a juridicidade represente dispensa ou, até mesmo, desrespeito ao princípio da legalidade. Ou seja, a discordância refere-se à possibilidade de atuação administrativa independente ou contra a lei.

Já BINENBOJM adota posição divergente. O autor em questão admite a existência de atividades administrativas que, não só, não estejam habilitadas por lei, mas também que sejam contrárias à lei, caso esteja pautado no ordenamento como um todo ${ }^{60}$. A primeira hipótese deve-se ao fato de que, caso fosse exigida lei para efetivação de um direito constitucional, toda a lógica hierárquica estaria sendo subvertida. Ou seja, é preciso sempre ter mente que os mandamentos constitucionais irradiam por toda a ordem jurídica, e devem ser efetivados, ainda que em hipótese de omissão legislativa. Prosseguindo na esteira de atuação administrativa praeter legem, é necessário que seja lembrado que, para BINENBOJM, tal atuação só seria válida em hipótese de ampliação, ou ainda, promoção de direitos fundamentais. Dessa forma, será descabida uma atuação administrativa para além da lei tratando-se

\footnotetext{
objetivos jurídicos da sociedade, enquanto aquele desenvolvido por Maurice Hauriou abrange todas as normas, dentre as quais incluem-se os princípios gerais de direito, fruto da jurisprudência.

59 ARAGÃO, Alexandre Santos de. A Concepção Pós-Positivista do Princípio da Legalidade, in Revista de Direito Administrativo, v. 256.

60 "Isso significa que a atividade administrativa continua a realizar-se, via de regra, (i) segundo a lei, quando esta for constitucional (atividade secundum legem), (ii) mas pode encontrar fundamento direto na Constituição, independente ou para além da lei (atividade praeter legem), ou, eventualmente, (iii) legitimar-se perante o direito, ainda que contra a lei, porém com fulcro numa ponderação da legalidade com outros princípios constitucionais (atividade contra legem, mas com fundamento numa otimizada aplicação da Constituição)." (BINENBOJM, Gustavo. Op. cit. p. 38).
} 
de restrição a direitos fundamentais, esta sim devendo sempre ser precedida por lei.

É importante lembrar que caso uma atividade da Administração Pública viole a lei, esta atividade é, obviamente, ilegal e deve, em princípio, ser anulada. Isso porque é dever da Administração e, em última hipótese, do Judiciário anular atos que contrariam a lei. No entanto, de acordo com BINENBOJM, caso este ato esteja de acordo com a ordem jurídica em sua inteireza, ou seja, caso esteja de acordo com a juridicidade, ele pode ser considerado válido. Ou seja, mesmo indo contra um preceito legal, caso o ato seja adequado ao ordenamento como um todo, pode ser considerado válido, através de instrumentos como a convalidação ou sanatória. Isso ocorre, como destacado por RAFAEL OLIVEIRA, por que muitas vezes é preferível que se considere o ato que violou uma lei como válido, evitando-se agravar os efeitos jurídicos produzidos, ou seja, para evitar violações à boa-fé e a segurança jurídica, mediante ponderação de interesses ${ }^{61}$.

Isto posto, passa-se a uma análise acerca das diferentes espécies normativas e seus limites, à luz da legalidade e juridicidade.

${ }^{61}$ OLIVEIRA, Rafael Carvalho Rezende. Op. Cit. p.82-83. 


\section{CAPÍTULO II - NÍVEIS FUNDAMENTAIS DE FONTES DO DIREITO SUBMETIDOS À HIERARQUIA CONSTITUCIONAL: A LEI E O REGULAMENTO}

No presente Capítulo, será procedida uma investigação acerca da lei e do regulamento, por serem estes as fontes do direito submetidos à hierarquia da Constituição Federal. Para tanto, será analisada inicialmente a lei, com especial atenção a algumas de suas concepções, até que se chegue à sua atual percepção e suas características principais. Posteriormente, será estudado o regulamento, a partir do enfoque do poder normativo da Administração Pública, e questões controversas acerca do tema.

\section{I - A Lei}

$\mathrm{O}$ conceito de lei se refere, tradicionalmente, à espécie normativa, produto da atividade parlamentar, que ocupa posição imediatamente abaixo da Constituição na pirâmide das normas. Ou seja, a lei é, apenas e tão somente, subordinada à Constituição. Devemos lembrar ainda que, no Brasil, a Constituição conferiu força de lei a quatro espécies normativas: leis ordinárias, leis delegadas, leis complementares e medida provisória nos termos do artigo 59, incisos II a V da Constituição Federal, como salientado por BINENBOJM ${ }^{62}$. No entanto, antes de passarmos às próximas considerações e para uma melhor

\footnotetext{
${ }^{62}$ BINENBOJM, Gustavo. Op. cit. p. 147. A posição do autor quanto à possibilidade de se conferir a medida provisória status de lei encontra divergência na doutrina. Celso Antônio Bandeira de Mello não concorda com a afirmação do autor, optando por conferir apenas força de lei à medida provisória. De forma a corroborar sua posição, estabelece as diferenças entre medida provisória e lei, segundo as quais a primeira seria dotada, em linhas gerais, de excepcionalidade, efemeridade e precariedade. (MELLO, Celso Antônio Bandeira de. Op. Cit. p.130-133.)
} 
compreensão acerca destas, é imprescindível que retornemos ao histórico desta espécie normativa, como salientado por CANOTILHO ${ }^{63}$.

Em HoBBES, verifica-se uma concepção voluntarista da lei, uma vez que a lei é responsável por exercer um comando sobre a sociedade. Nesse momento, valoriza-se também o aspecto positivista da lei, por ser a mesma, a palavra do soberano, que exerce o poder sobre os indivíduos ${ }^{64}$. LOCKE e MONTESQUIEU, abordados anteriormente, são responsáveis por fazer uma conexão da lei com a liberdade e separação de poderes, com cunho garantista e liberal, superando a noção de HOBBES na qual a lei é uma ordem à sociedade. A análise de ROUSSEAU, por sua vez, foi responsável por agregar a noção de generalidade da lei, não mais tão somente em uma dimensão de universalidade, defendida por autores da filosofia antiga, mas também por considerar a lei um produto da vontade geral. Dessa maneira, a lei seria fruto de um interesse comum da sociedade, fazendo surgir nesse momento a noção de que a lei, representando produto deste interesse de toda a sociedade, seria instrumento para garantir a igualdade política ${ }^{65}$.

Retornando à atual concepção de lei, a definição conferida pela Comissão Interamericana de Direitos Humanos seria a da lei como "la norma

\footnotetext{
${ }^{63}$ CANOTILHO, J. J. Gomes. Op. cit. p. 713-715.

64 “[... o consentimento de um súdito ao poder soberano está contido nas palavras eu autorizo, ou eu assumo como minhas, todas as suas ações, nas quais não há qualquer espécie de restrição a sua antiga liberdade natural." É importante ressaltar que tal consentimento não era irrestrito: " Portanto, quando nossa recusa de obedecer prejudica o fim em vista do qual foi criada a soberania, não há qualquer liberdade de recusar; mas caso contrário há essa liberdade.” (HOBBES, Thomas. Leviatã..cap. XXI, p. 133) Tradução de João Paulo Monteiro e Maria Beatriz Nizza da Silva. Os clássicos da Política. In: RIBEIRO, Renato Janine. Hobbes: o medo e a esperança. In: WEFFORT, Francisco. Os clássicos da política. I. $13^{\mathrm{a}}$ Ed., $12^{\mathrm{a}}$ reimpressão. São Paulo: Ática, 2005. p. 69.
}

\footnotetext{
${ }^{65}$ ROUSSEAU, Jean-Jaques.. Du contrat social ou Principes du droit politique. Paris, Éditions Garnier, 1954. P. 97-240. Tradução de Cid Knipell Moreira. Os clássicos da Política. In: NASCIMENTO, Milton Meira de. Rouseau: da servidão à liberdade. In: WEFFORT, Francisco. Os clássicos da política. I. São Paulo: Ática, 13ª Ed., 12ª reimpressão, 2005. p. 219-220.
} 
jurídica de carácter general, ceñida al bien común, emanada de los organos legislativos constitucionalmente previstos y democraticamente elegidos y elaborada según el procedimiento estabelecido por las constituiciones de los Estados partes para la formación de las leys" ${ }^{66}$. Como bem salientou CELSO ANTÔNIO BANDEIRA DE MELlO, o fato de ser fruto do Legislativo, órgão no qual estarão reunidas diversas correntes ideológicas, representantes de grupos sociais distintos, nos leva a crer, com mais veemência, que a lei representa, de fato, um produto da vontade da sociedade. Ainda para o autor, o processo de elaboração das leis, com ampla publicidade e reexames constantes, também é responsável por dotá-las de maior controle, e consequentemente, maior proteção à sociedade ${ }^{67}$.

É importante ressaltar que, em decorrência da já mencionada subordinação estrita à Constituição, surge outra característica basilar desta espécie normativa. Esta característica reside no fato de que somente a lei seria capaz de inovar no ordenamento jurídico, por isso sua distinção quanto aos regulamentos. Tal afirmação advém do fato de que a lei tem natureza de ato normativo primário, ao contrário do regulamento, que possui natureza de ato normativo secundário ou derivado ${ }^{68}$. Assim, segundo OSWALDO ARANHA BANDEIRA DE MELlO, “a lei inova originariamente na ordem jurídica, enquanto o regulamento não a altera (....)" ${ }^{6}$, não obstante posições contrárias, que serão abordadas com mais detalhamento no tópico seguinte, ao tratarmos da disciplina dos regulamentos e do poder regulamentar.

Além do exposto, a doutrina é responsável por fazer uma distinção entre os aspectos formal e material da lei, na qual, o aspecto formal é aquele que

\footnotetext{
${ }^{66}$ Opinión Consultiva $n^{\circ}$ 6, párrafos 32.

${ }^{67}$ MELLO, Celso Antônio Bandeira de. Op. cit. p. 363-364. Não se pode esquecer sobre o exposto anteriormente acerca da crise da lei, o que nos levaria a uma nova análise no tocante a visão da sociedade sobre a lei no atual contexto.

68 "Sob o enfoque de que os atos podem ser originários e derivados, o poder regulamentar é de natureza derivada (ou secundária): somente é exercido à luz de lei preexistente. Já as leis constituem atos de natureza originária (ou primária), emanando diretamente da Constituição." (CARVALHO FILHO, José dos Santos. Op. cit. p. 53)

${ }^{69}$ MELlO, Oswaldo Aranha Bandeira de. Principios Gerais de Direito Administrativo. v. I. $3^{\mathrm{a}}$ Edição. São Paulo: Malheiros, 2007. p. 373.
} 
identifica a lei como fruto do processo legislativo, exercido pelo poder constitucionalmente legislativo. Já o sentido material indica que é lei aquele ato geral, abstrato, e obrigatório para todos, indistintivamente. Nesse sentido, as lições de CANOTILHO esclarecem que a identificação de lei como regra geral faria menção a dois sentidos: o primeiro de ser uma deliberação tomada em abstrato, e o segundo, da lei ser direcionada a todo e qualquer indivíduo ${ }^{70}$. Contudo, a posição de Oswaldo Aranha Bandeira De Mello é a de que o sentido material da lei retromencionado, também faria parte do aspecto formal da lei, uma vez que não diz respeito à matéria a ser abordada pela lei, mas tão somente a seu conteúdo formal ${ }^{71}$. Cabe salientar que tal distinção tem importância reduzida se comparada à análise das formas na quais a superioridade da lei em relação aos regulamentos é evidenciada, feita por JUAN ALFONSO SANTAMARÍA PASTOR ${ }^{72}$.

A primeira das formas seria a noção de que a lei ocupa posição de primazia formal sobre o regulamento devido à função que cada um exerce no ordenamento jurídico. Isso porque cabe à lei ser a diretriz na disciplina das matérias, ou seja, a lei regula essencialmente as matérias, restando aos regulamentos, os detalhes, apenas. Assim, o autor afirma que a lei ocupa um lugar central na ordem jurídica, em oposição à marginalidade dos regulamentos, advindo deste ponto a noção de complementariedade do regulamento, que será abordada no tópico destinado aos regulamentos.

O segundo aspecto seria o da lei exercer também primazia material em relação aos regulamentos, uma vez que, os regulamentos não podem, de forma

\footnotetext{
70 "Por regra geral entendia-se: (1) uma deliberação tomada, não em concreto, em vista de um caso particular e actual, mas em abstracto para regular todos os casos da mesma natureza que no presente ou no futuro possam ser abrangidos pela disposição legal; (2) uma disposição que não é tomada em face de um ou vários indivíduos determinados, mas que se destina a ser aplicada a todos os indivíduos nas condições previstas pelo texto." (CANOTILHO, J. J. Gomes. Op. cit. p. 715.)

${ }^{71}$ MELLO, Oswaldo Aranha Bandeira de. Op. cit .p. 237

72 SANTAMARÍA PASTOR, Juan Alfonso. Principios de Derecho Administrativo. v. I. $3^{\text {a }}$ Edição. Madrid: Centro de Estudios Ramón Areces, S.A, 2000. p. 322-324.
} 
alguma, estabelecer preceitos contrários aos dispostos em lei, o que é vislumbrado no princípio da preferência da lei, decorrente do princípio da legalidade ${ }^{73}$. Dessa forma, de acordo com a também chamada primazia de conteúdo, existiria uma invulnerabilidade da lei frente às disposições regulamentares, já que, em caso de desacordo, o regulamento deve ceder espaço ao estabelecido em lei. A explicação para isso seria a legitimidade democrática do Poder Legislativo, que exerce, em termos de normatividade, função preponderante quando comparada à exercida pela Administração Pública, mencionada anteriormente. Ainda, do princípio da preferência de lei, decorre o chamado princípio do congelamento do grau hierárquico, consistente na ideia de que caso uma norma pretenda alterar, modificar ou substituir outra já existente, deve possuir hierarquia normativa no mínimo igual daquela norma já existente. Assim, caso uma lei regule certa matéria, somente outra lei pode modificá-la ou revogá-la. O princípio, no entanto, como salientado por CANOTILHO, não impede a deslegificação, vista anteriormente, já que a própria lei permite que a matéria seja normatizada por via de regulamento. Fato diverso ocorre se a Constituição vedar que a matéria seja regulada por ato da Administração, situação na qual a deslegificação seria inconstitucional ${ }^{74}$.

Chegamos então à terceira forma de manifestação de superioridade da lei, designada pelo autor como primazia objetiva. Este terceiro aspecto, também chamado de primazia de âmbito, manifesta-se de diferentes maneiras que abordaremos a seguir. A primeira delas seria a noção de que a Constituição reserva às leis uma série de matérias, consistindo em reserva material de lei, e, caso tal matéria seja pormenorizada por regulamentos, estes terão um espaço

\footnotetext{
73 "O regulamento não pode contrariar um acto legislativo ou equiparado. A lei tem absoluta prioridade sobre os regulamentos, proibindo-se expressamente os regulamentos modificativos, suspensivos ou revogatórios das leis (cfr. Art. 112\%/6)."(CANOTILHO, J. J. Gomes. Op. cit. p. 835.)

${ }^{74}$ CANOTILHO, J. J. Gomes. Op. cit. p. 841.
} 
consideravelmente reduzido. Neste ponto, torna-se claro o cunho garantista, evitando possíveis desrespeitos à liberdade e propriedade dos indivíduos. A segunda forma de manifestação da primazia objetiva seria a ideia de que a lei pode intervir em qualquer matéria a ser regulada pelo direito, e não somente àquelas reservadas constitucionalmente à lei. Assim, não existiria limitação material alguma à regulação legal, vislumbrando-se, desta forma, uma reserva total de lei. A terceira maneira de se visualizar a primazia de âmbito consiste no fato de não existir reserva regulamentar, ou seja, a Constituição não reservou a nenhuma matéria uma regulação por via de regulamentos. Prosseguindo, a última das expressões da primazia de objeto seria a de que a lei possui disponibilidade acerca dos limites a serem impostos aos regulamentos, tendo poderes para ampliar e restringir os mesmos. Mais que isso, a lei pode até mesmo estabelecer uma proibição de atuação regulamentar sobre determinada matéria.

O último aspecto no qual se evidencia a supremacia da lei, relacionado por SANTAMARÍA PASTOR, seria o fato de a lei ter total disponibilidade acerca do conteúdo e também da vigência do regulamento, no que consiste a primazia diretiva. Assim, cabe a lei, além de estabelecer os princípios e objetivos a serem atingidos, definir qual conteúdo deve estar previsto no regulamento e aquele que não poderá estar. Cabe ainda à lei definir o período no qual o regulamento estará vigendo, o âmbito territorial de vigência, entre outros.

A partir das observações acima, fica clara a relevância dos princípios da separação de poderes e da legalidade para nortear a doutrina da relação entre lei e regulamento, uma vez que, do primeiro, decorre a noção de reserva material e formal de lei, enquanto do segundo, decorre o princípio da preferência de lei. Isto posto, torna-se possível avançar na análise do poder regulamentar e espécies de regulamentos. 


\section{II - Poder Regulamentar e graus de regulamentação}

O poder regulamentar conferido à Administração Pública insere-se nas funções atípicas do Poder Executivo, representando função normativa que exerce tal poder. Importante então lembrar que o poder regulamentar nada mais é que espécie do gênero função normativa, na qual também é inserida a função legislativa. Dessa forma, assim como o poder legislador, o poder regulamentador também é responsável por expedir atos normativos de caráter geral, abstrato e impessoal ${ }^{75}$. O que os difere são os argumentos mencionados anteriormente acerca da supremacia da lei, responsável por agregar ao poder regulamentar o princípio da complementariedade. Assim, em uma concepção rígida da legalidade, cabe ao regulamento, exercendo função secundária, apenas complementar o disposto previamente em lei, esta ocupando posição central da ordem jurídica.

É importante esclarecer a divergência na doutrina acerca do produto do poder regulamentar. Existem autores, como CELSO ANTÔNIO BANDEIRA DE MELLO, que afirmam que o poder regulamentar realiza-se somente através de decretos, de expedição do Chefe do Poder Executivo ${ }^{76}$. Nesse sentido, seria feita a distinção entre regulação (atribuição do órgão regulador) e regulamentação, na qual a primeira representaria uma mera função tecnicista, enquanto a segunda, seria fruto da função política exercida pelo Chefe do Executivo. Contudo, a posição defendida por BINENBOJM é a de que poder regulamentar é aquele exercido não só pelo Chefe do Executivo, mas também pelos órgãos reguladores. Isso pautado no princípio da eficiência, na noção de uma Administração Pública policêntrica e na previsão constitucional de

\footnotetext{
${ }^{75}$ CARVALHO FILHO, José dos Santos. Op. cit. p. 36.

76 "É certo, entretanto, que, na imensa maioria dos casos, embora não em todos, o emissor dos atos assim denominados é a Administração Pública, sendo de convir, então, que o sentido principal da voz "regulamento" está reportado a atos emitidos pelo Chefe do Poder Executivo." (MELLO, Celso Antônio Bandeira de. Op. cit. p. 335-336).
} 
delegação de funções às agências reguladoras, constante do artigo $174^{77}$. Assim, a diferença entre ambos seria apenas o seu âmbito de aplicação, já que, o regulamento setorial seria aplicável apenas ao determinado setor no qual esteja incidindo a regulação. $\mathrm{O}$ regulamento expedido pelo Chefe do Executivo, por sua vez, seria aplicado de forma geral.

$\mathrm{O}$ conceito de regulamento seria justamente aquele que o considera como um ato geral e, mais usualmente, abstrato com a "estrita finalidade de produzir as disposições operacionais uniformizadoras necessárias à execução da lei cuja aplicação demanda atuação da Administração Pública". ${ }^{78}$ A função do regulamento, extraída de seu conceito, nos remete a uma importante questão a ser analisada, qual seja, a dúvida acerca da possibilidade de inovação dos regulamentos no ordenamento jurídico, rechaçada fortemente por autores consagrados da doutrina, como explicitado acima, nas lições de OSWALDO Aranha BandeIra De Mello. Para tais autores, o ordenamento jurídico brasileiro foi muito claro ao estabelecer que somente a lei seria capaz de obrigar alguém a fazer ou deixar de fazer algo, disposição constante do artigo $5^{\circ}$, inciso II da Constituição da República, símbolo da valorização do princípio da legalidade estrita. Tal disposição representa corolário do Estado do Direito, com forte apego à noção de uma administração mera executora de leis. Assim, os regulamentos teriam como objeto a disciplina de "situações em que cabe discricionariedade administrativa no cumprimento da lei”, como afirmou CELSO ANTÔNIO BANDEIRA DE MELlo ${ }^{79}$.

\footnotetext{
77 “Art. 174. Como agente normativo e regulador da atividade econômica, o Estado exercerá, na forma da lei, as funções de fiscalização, incentivo e planejamento, sendo este determinante para o setor público e indicativo para o setor privado."

78 MELlO, Celso Antônio Bandeira de. Op. Cit. 339.
} 
EISENMANN, por exemplo, adota posição divergente, defendendo o exercício de atividade criativa também por regulamentos, caso contrário, estes não teriam utilidade alguma. Apoiando tal posição está a lição de KELSEN, na chamada teoria da atribuição normativa precedente, segundo a qual, mesmo sendo fundamental que o regulamento esteja previamente habilitado por lei, este possui âmbito de inovação. A razão para isso seria que nenhuma norma, nem mesmo a lei, seria dotada de completude, sendo necessária a existência de um regulamento para pormenorizá-la. Dessa forma dispôs JosÉ DOS SANTOS CARVALHO FILHO, ao considerar legítima a imposição de obrigações por regulamentos, uma vez que sejam estas subsidiárias e adequadas às prévias disposições legais ${ }^{80}$.

Assim, todo regulamento seria, nas palavras de AlEXANDRE SANTOS DE ARAGÃo, não só executivo, mas também criativo ${ }^{81}$. O autor foi ainda além, ao afirmar que a grande problemática no tocante ao poder regulamentar seria a densidade normativa necessária da lei habilitadora, de forma que a consequente regulamentação pelo Executivo se coadune com os preceitos constitucionais. Ainda, tratando-se de lei de conteúdo demasiadamente aberto, seria nesta que incorreria a inconstitucionalidade, ou seja, não estaríamos em face de ilegalidade do regulamento, mas sim de inconstitucionalidade da lei que atribuiu poderes à Administração Pública. Mais ainda, defendeu que, caso mantenha-se a lei de conteúdo aberto, é preferível que se permita uma regulamentação, de forma a evitar tratamentos desiguais no momento de sua aplicação. Já que, sem um regulamento para pormenorizar a matéria, dificilmente se chegaria a uma atuação uniforme por parte da Administração, trazendo insegurança jurídica para a sociedade.

\footnotetext{
${ }^{80}$ CARVALHO FILHO, José dos Santos. Op. cit. p. 55.

81 ARAGÃO, Alexandre Santos de. A Concepção Pós-Positivista do Princípio da Legalidade, in Revista de Direito Administrativo, v. 256.
} 


\section{II. 1 - A delegação disfarçada}

Desta maneira chega-se à questão da delegação disfarçada, na qual a lei dispõe somente de uma pretensa transferência da atribuição normativa ao Executivo para instituir direitos e/ou obrigações. Tal instrumento é rechaçado de forma veemente pela doutrina brasileira por razões diversas, expostas a seguir. A primeira destas razões seria o fato de a Constituição expressamente estabelecer, em seus artigos 62 e 68, as hipóteses de transferência ao Executivo da função normativa e suas limitações ${ }^{82}$. Outro fator seria a tripartição de poderes, que seria claramente violada caso um poder delegasse funções a outro. A terceira razão, não obstante a não-inclusão pelo legislador originário na Constituição Federal de 1988 da disposição prevista no artigo 6º,$\S$ único da Constituição de 1967, é a regra constante do artigo 25, inciso I, do Ato das Disposições Constitucionais Transitórias ${ }^{83}$. É exatamente com base na defesa da não-delegação de funções que muitos autores, como BINENBOJM, rechaçam o enquadramento da tese da deslesgificação, abordada anteriormente, no direito brasileiro. De acordo com esse entendimento doutrinário, a deslegalização,

\footnotetext{
82 “Art. 62. Em caso de relevância e urgência, o Presidente da República poderá adotar medidas provisórias, com força de lei, devendo submetê-las de imediato ao Congresso Nacional."

"Art. 68. As leis delegadas serão elaboradas pelo Presidente da República, que deverá solicitar a delegação ao Congresso Nacional. $\S 1^{\circ}$ - Não serão objeto de delegação os atos de competência exclusiva do Congresso Nacional, os de competência privativa da Câmara dos Deputados ou do Senado Federal, a matéria reservada à lei complementar, nem a legislação sobre: I - organização do Poder Judiciário e do Ministério Público, a carreira e a garantia de seus membros; II - nacionalidade, cidadania, direitos individuais, políticos e eleitorais; III - planos plurianuais, diretrizes orçamentárias e orçamentos. (...)"

${ }^{83}$ A Constituição de 1967 vedava a delegação de poderes de forma expressa:

“Art $6^{\circ}$ - São Poderes da União, independentes e harmônicos, o Legislativo, o Executivo e o Judiciário. Parágrafo único - Salvo as exceções previstas nesta Constituição, é vedado a qualquer dos Poderes delegar atribuições; o cidadão investido na função de um deles não poderá exercer a de outro." Ainda sobre a questão, segue "Art. 25, ADCT: Ficam revogados, a partir de cento e oitenta dias da promulgação da Constituição, sujeito este prazo a prorrogação por lei, todos os dispositivos legais que atribuam ou deleguem a órgão do Poder Executivo competência assinalada pela Constituição ao Congresso Nacional, especialmente no que tange a: I - ação normativa; (...)”
} 
chamada de delegação legislativa inominada, representa verdadeira fraude ao processo legislativo. ${ }^{84}$

\section{II. 2 - O controle ao poder regulamentar}

De forma a evitar situações de desrespeito ao ordenamento jurídico, como a vista acima, é imprescindível que o mesmo possua instrumentos de controle do poder regulamentar. O direito brasileiro possui duas formas de controle de tal atividade administrativa, quais sejam, o controle pela via do Poder Legislativo e aquele exercido pelo Poder Judiciário.

O controle exercido pelo Legislativo está previsto expressamente na Constituição Federal da República, em seu artigo 49, inciso V, o qual atribui ao Congresso Nacional a competência para sustar atos normativos da Administração Pública, que extrapolem os limites do poder regulamentar ou à delegação legislativa, prevista no artigo $68^{85}$. Já o controle pelo Judiciário pode dar-se de formas diversas. A primeira delas será na hipótese de regulamento que viole uma lei, ou seja, disponha para além ou contra a lei, tratando-se de hipótese de controle de legalidade. Situação distinta é aquela na qual o ato normativo expedido pela Administração Pública viola a Constituição da República de forma direta. Neste caso, um dos instrumentos cabíveis é arguição de descumprimento de preceito fundamental, prevista no artigo 102,

\footnotetext{
${ }^{84}$ BINENBOJM, Gustavo. Op. cit. p. 283-288.

85“"Art. 49. É da competência exclusiva do Congresso Nacional:

$\mathrm{V}$ - sustar os atos normativos do Poder Executivo que exorbitem do poder regulamentar ou dos limites de delegação legislativa;"

Sobre a questão: “[...]essa atribuição, prevista no art. 49, inciso V, constitui inovação da Constituição de 1988, da maior relevância, porque permitirá ao Poder Legislativo controlar, mediante provocação ou por iniciativa própria, a legalidade dos atos normativos do Poder Executivo, sustando os seus efeitos independente de prévia manifestação do Poder Judiciário ”" (DI PIETRO, Maria Sylvia Zanella. Direito Administrativo. 22a ed. São Paulo: Atlas, 2009, p. 740)
} 
$\S 1^{\circ}$, da Constituição Federal. O instrumento retromencionado foi fundamental para que se confirmasse um controle efetivo de todo e qualquer produto do poder regulamentar, isso porque anteriormente, o controle de constitucionalidade dos atos normativos expedidos pela Administração, somente ocorreria tratando-se de ato normativo autônomo, ou seja, que não estivesse precedido por lei. Tal entendimento provinha de orientação do Supremo Tribunal Federal. Ainda, pode-se pensar no controle não só da ação, mas também de uma possível omissão administrativa em regulamentar determinada matéria. Assim, caso tal atividade seja necessária à aplicação de determinada lei e a consequente efetivação de algum direito por parte dos administrativos, é cabível que se mova mandado de injunção. A jurisprudência avançou e hoje, é admitido que seja estipulado prazo para constituição em mora da Administração Pública inerte no poder de regulamentar ${ }^{86}$.

\section{II. 3 - Espécies de poder regulamentar}

Avançando na análise do poder regulamentar, é imprescindível que se discuta suas possíveis espécies. De acordo com JosÉ DOS SANTOS CARVALHO FILHO, existem diferentes graus de regulamentação, quais sejam, primeiro e segundo grau. O primeiro grau seria constituído por decreto e regulamentos, enquanto o segundo, composto por atos subordinados aos chamados atos de primeiro grau, como instruções e resoluções. Contudo, para BINENBOJM, o decreto seria o instrumento de formalização dos regulamentos expedidos pelo Chefe do Executivo.

A classificação histórica dos regulamentos consiste na diferenciação entre regulamentos de execução, independentes ou de necessidade, como formulada por SANTAMARÍA PASTOR. Os regulamentos de execução seriam

\footnotetext{
${ }^{86}$ CARVALHO FILHO, José dos Santos. Op. cit. p. 57-58.
} 
aqueles autorizados por lei, representando uma atuação secundum legem. Tais regulamentos consistem, dessa forma, em uma remissão normativa. Os regulamentos independentes ou autônomos, por sua vez, seriam aqueles consistentes em atuação administrativa praeter legem, ou seja, expedidos pelo Executivo em matérias nas quais não houve normatização por lei e nem, ao menos, autorização. Já os regulamentos de necessidade representariam uma prática anormal, utilizada em situações de emergência, sejam estas por razões políticas, econômicas ou sociais. Os regulamentos de necessidade estariam sujeitos a limites claros, como a vigência, que só ocorre enquanto durar a situação de emergência, já que representam uma atividade contra legem ${ }^{87}$.

Para Binenbojm, os regulamentos, considerados como lei em sentido material, dividiriam-se em regulamentos de execução e regulamentos autônomos. ${ }^{88}$ Os regulamentos de execução, de acordo com o artigo 84, inciso IV, da Constituição Federal, tem função de "instrumentalizar a execução da lei" ${ }^{89}$, sendo aplicados sempre secundum legem. Assim, não cabe ao regulamento executivo regular determinada matéria de forma contrária ao estabelecido em lei, ou para além da mesma. No entanto, é importante que não se reduza de maneira tão profunda a função do regulamento executivo. Isso porque sua função prática não é de simplesmente aplicar a lei, uma vez que, como visto anteriormente, toda concreção de normas envolve inovação, salvo em caso de reserva absoluta de lei.

Os regulamentos autônomos, por sua vez, despertam inúmeras discussões doutrinárias. Tal instrumento seria aquele expedido pela Administração Pública, sem que haja uma lei habilitadora. Ou seja, tal espécie de regulamento

\footnotetext{
${ }^{87}$ SANTAMARÍA PASTOR, Juan Alfonso. Op cit. p. 325-328.

${ }^{88}$ BINENBOJM, Gustavo. Op. cit. p. 152.

${ }^{89}$ Ibid. p. 156.
} 
retira sua validade diretamente da Constituição Federal ${ }^{90}$. Contudo, deve-se ressaltar que a doutrina majoritária não admite a existência do decreto autônomo no direito brasileiro. A discussão acerca da possibilidade de edição dos regulamentos autônomos ou independentes nos leva a rememorar as diferenças entre os regimes constitucionais de 1967 e 1988 alusivas ao tema.

A Constituição de 1967 conferia mais força à parcela doutrinária defensora da existência dos chamados regulamentos autônomos, uma vez que, em seu artigo 81, inciso $\mathrm{V}$, conferia competência exclusiva ao Chefe do Executivo para "dispor sobre a estruturação, atribuições e funcionamento da administração." Nesse momento, não obstante posições contrárias, o debate girava em torno da concepção do âmbito desta espécie normativa, e não de sua existência, como ressaltado por BINENBOJM ${ }^{91}$.

Tal situação foi alterada quando da superveniência da Constituição Federal de 1988, pois a competência do Chefe do Executivo foi suprimida com a introdução de exigência da matéria retromencionada somente ser passível de regulação "na forma da lei", agora no artigo 84, inciso VI. Na nova conjuntura, HELY LOPES MEIRELLES permaneceu defendendo, de forma isolada na doutrina, a possibilidade de edição de regulamentos autônomos, com observância do princípio da legalidade em suas duas concepções, quais sejam, de precedência e reserva de lei ${ }^{92}$.

Foi, no entanto, a Emenda Constitucional n 32 de 2001 que reacendeu os debates acerca da possibilidade ou não de edição, no ordenamento brasileiro, dos regulamentos autônomos. Isso porque a Emenda Constitucional em comento retirou a expressão "na forma da lei" do artigo 84, inciso VI,

\footnotetext{
90 “A pretensão dos regulamentos autônomos caracterizados como (1) regulamentos não carecidos de lei prévia para intervir (2) não complementares ou executivos de qualquer lei [...] ’(CANOTILHO, J. J. Gomes. Op. cit. p. 838)

${ }^{91}$ BINENBOJM, Gustavo. Op. cit. p. 163.

${ }^{92}$ MEIRELLES, Hely Lopes. Op. Cit. p. 162.
} 
alínea ' $a{ }^{93}$. Dessa forma, foi reintroduzida a competência exclusiva do Chefe do Executivo para dispor sobre "organização e funcionamento da administração federal, quando não implicar aumento de despesa nem criação ou extinção de órgãos públicos". Ainda, a Emenda $n^{\circ} 32$ retirou certas competências normativas do Congresso Nacional, contidas no artigo 48, incisos X e XI, transferindo-as para o Presidente da República ${ }^{94}$. Além disso, ocorreu a alteração das iniciativas privativas do Chefe do Executivo, previstas na alínea "e" do inciso II do $\S 1^{\circ}$ do artigo 61 da Constituição Federal ${ }^{95}$. Foi também promovida uma alteração no artigo 88 da Constituição Federal, afastando a necessidade de lei para estruturação e atribuições dos Ministérios 96

Assim, a doutrina voltou a discutir o enquadramento ou não da espécie normativa em comento no direito brasileiro. Parte dela considera inconcebível a existência do regulamento autônomo no direito brasileiro, por acreditar que representariam poder legiferante "indireto e dissimulado" ${ }^{97}$. Estes autores fundamentam-se em uma legalidade estrita, partindo da compreensão do artigo $5^{\circ}$, inciso II, da CRFB, que exige lei para imposição de obrigações, além de recorrerem à legalidade administrativa, previsão constitucional do caput do artigo 37. Pode-se ainda utilizar como argumento contrário à possibilidade de existência dos regulamentos autônomos, a competência do Congresso para

93 "X - criação, transformação e extinção de cargos, empregos e funções públicas, observado o que estabelece o art. 84, VI, b; XI - criação e extinção de Ministérios e órgãos da administração pública;”

${ }^{94}$ Redação incisos X e XI do artigo 48:

"X - criação, transformação e extinção de cargos, empregos e funções públicas, observado o que estabelece o art. 84, VI, b; XI - criação e extinção de Ministérios e órgãos da administração pública;"

\footnotetext{
${ }^{95}$ Redação da alínea "e" do $§ 1^{\circ}$, inciso II, do artigo 61:

“e) criação e extinção de Ministérios e órgãos da administração pública, observado o disposto no art. $84, \mathrm{VI}$ "

96 “Art. 88. A lei disporá sobre a criação e extinção de Ministérios e órgãos da administração pública."

${ }^{97}$ CARVALHO FILHO, José dos Santos. Op. cit. p. 60.
} 
sustar atos do Executivo que exorbitem o poder regulamentar, prevista no artigo 84, inciso IV, além do artigo 25, inciso I do ADCT, proibitiva de edição de decretos autônomos, ambos abordados anteriormente.

Ademais, parte da doutrina discorda da ideia de que o decreto estabelecido no artigo 84, inciso VI, alínea "a", possa ser considerado autônomo. Isso porque nesse dispositivo estão disciplinas matérias de mera organização, sendo considerado, desta forma, um decreto meramente interno. Para estes autores, como JosÉ dos SAnTOS CARVAlHO FILHO, o decreto organizacional, por não criar direitos e obrigações para terceiros de forma direta, não se enquadra na espécie decreto autônomo, esta, por sua vez, incongruente com o ordenamento brasileiro pelas razões acima expostas ${ }^{98}$.

Para BINENBOJM, haveria outras duas posições a serem abordadas sobre o tema. A primeira delas seria a de que a Emenda Constitucional $n^{\circ} 32$ de 2001, fez surgir no ordenamento brasileiro uma reserva administrativa ${ }^{99}$, uma vez que, a disposição constante do artigo 84, inciso VI, alínea "a" teria formado um núcleo de obstáculo à atuação de lei em sentido formal. $\mathrm{O}$ autor, no entanto, acredita que pensar em um âmbito de reserva administrativa não encontra respaldo com os limites materiais ao poder de reforma constitucional. Isso deve-se ao fato de que o princípio da preferência de lei representa garantia dos cidadãos e consequência da separação de Poderes, como já vimos. Mais ainda, possui “eficácia de bloqueio em relação a propostas de emenda

\footnotetext{
${ }^{98}$ CARVALHO FILHO, José dos Santos. Op. cit. p. 60. Sobre a questão: "Este é o regulamento previsto no art. 84, VI, "a". Mera competência para um arranjo intestino dos órgãos e competências já criados por lei. Como é possível imaginar que isto é equivalente aos regulamentos independentes ou autônomos do Direito europeu, cuja compostura, sabidamente, é muitíssimo mais ampla?"(MELLO, Celso Antônio Bandeira de. Op. cit. p. 338-339).

${ }^{99}$ Sobre a reserva de administração, lecionou CANOTILHO: "Por reserva de administração entende-se um núcleo funcional da administração "resistentes" à lei, ou seja, um domínio reservado à administração contra as ingerências do parlamento." (CANOTILHO, J. J. Gomes. Op. cit. p.739). Acerca da reserva de jurisdição: "A ideia de reserva de jurisdição implica a reserva de juiz (Richtervorbehalt) relativamente a determinados assuntos. Em sentido rigoroso, reserva de juiz significa que em determinadas matérias cabe ao juiz não apenas a última mas também a primeira palavra." (CANOTILHO, J. J. Gomes. Op. cit. p.664).
} 
constitucional, como também uma eficácia conformadora de dispositivos de emenda que comportem uma interpretação conforme." Já a terceira posição seria daqueles autores que defendem que a Constituição de fato legitimou a edição de decretos independentes neste dispositivo legal, sendo esta a posição do autor retromencionado, acompanhado por MARIA SYLVIA ZANELLA DI PIETRO ${ }^{100}$. Para BINENBOJM, no entanto, o princípio da legalidade, em suas duas concepções, deve ser observado, assim, lei superveniente seria capaz de alterar ou revogar tal regulamento, este sendo vedado nas hipóteses de reserva total de lei ${ }^{101}$.

Juntamente à discussão trazida pelo artigo 84, inciso VI, alínea "a", outros dois dispositivos levaram a um amplo debate acerca do poder normativo do Executivo, quais sejam, o artigo 103-B, $\S 4^{\circ}$, I e o $\operatorname{artigo} 130-\mathrm{A}, \S 2^{\circ}$, I, ambos da Constituição Federal da República. Por meio dos dispositivos expostos acima foram criados o Conselho Nacional de Justiça e o Conselho Nacional do Ministério Público, respectivamente, para os quais, a Constituição da República conferiu poderes normativos. O que se verifica é uma situação na qual, mesmo não fazendo parte da esfera do Poder Legislativo, a Constituição Federal conferiu poderes normativos para ambos os Conselhos, em matérias relacionadas a suas atribuições. Assim, tanto o Conselho Nacional de Justiça, quanto o Conselho Nacional do Ministério Público possuem poderes normativos primários, já que tem seu fundamento de validade retirado diretamente da Constituição, sendo desnecessária, desta forma, uma intermediação por meio de lei. Sobre a atuação do Conselho Nacional de Justiça já houve até mesmo manifestação positiva do Supremo Tribunal Federal quanto à sua competência para expedir decreto autônomo, vislumbrado

\footnotetext{
100 "No direito brasileiro, excluída a hipótese do art. 84, VI, com redação dada pela EC n³2, só existe o regulamento de execução, hierarquicamente subordinado a uma lei prévia, sendo ato de competência privativa do Poder Executivo.” (DI PIETRO, Maria Sylvia Zanella. Op. Cit. p. 92).

${ }^{101}$ BINENBOJM, Gustavo. Op. cit. p. 167-168.
} 
na ADC-MC 12/DF, julgada em 16 de fevereiro de 2006. Na decisão mencionada, o STF corroborou atuações do CNJ caso as mesmas estivesse pautadas em preceitos constitucionais, assegurando, no entanto, o princípio da preferência de lei ${ }^{102}$.

Ainda que não se fale em decreto independente, em respeito aqueles que defendem que decreto seja ato exclusivo do Chefe do Executivo, é notório que a Constituição conferiu poderes normativos originários a tais Conselhos, ou seja, poderes normativos autônomos. Nesse momento, com a atribuição de um poder normativo inovador da ordem jurídica a esses órgãos não legislativos, verifica-se uma clara releitura da legalidade.

Para BinenBOJM, num aprofundamento da doutrina de HELY LOPES MEIRELLES, além de tais hipóteses, o poder normativo autônomo seria válido sempre que este tenha como objetivo a satisfação dos direitos fundamentais, mesmo que não haja previsão expressa na Constituição, de forma contrária aos casos expostos ${ }^{103}$. Tal entendimento se coaduna com a constitucionalização do direito presente nos dias atuais, na qual a Administração Pública deve atuar concretamente para implementar os preceitos constitucionais, mesmo sem existência de lei prévia. Assim, quando o objetivo for a ampliação de direitos previstos na Constituição, direitos fundamentais principalmente, seria válida a atuação autônoma da Administração Pública. Nesse ponto devemos lembrar da observação, já mencionada, que caso o Administrador esteja em face de restrição de um direito para ampliação de outro, estaríamos diante de hipótese na qual a lei se faria necessária. Contudo, em face de direito previsto constitucionalmente e sem estarmos em situação de restrição a nenhum outro

\footnotetext{
${ }^{102}$ OLIVEIRA, Rafael Carvalho Rezende. Op. cit. p.59-60. Vide Informativo STF $\mathrm{n}^{\mathrm{o}}$ 516, de agosto de 2008.

103 "Decreto independente ou autônomo: é o que dispõe sobre matéria ainda não regulada especificamente em lei. A doutrina aceita esses provimentos administrativos praeter legem para suprir a omissão do legislador, desde que não invadam as reservas da lei, isto é, as matérias que só por lei podem ser reguladas. "(MEIRELLES, Hely Lopes. Op. Cit. p. 162).
} 
direito para concretização do mesmo, e tomando por base a noção de que a Constituição é a verdadeira diretriz normativa da atuação administrativa, o poder normativo autônomo é considerado perfeitamente plausível. ${ }^{104}$ Assim, retornamos à ideia do bloco da legalidade, de ALEXANDRE SANTOS DE ARAGÃO, para o qual todo o ordenamento, inclusive valores, princípios e objetivos da sociedade, deve ser responsável por atribuir competência ao administrador, e não apenas a lei formal ${ }^{105}$.

É importante lembrar ainda das lições de CANOTILHO, ao afirmar que os regulamentos autônomos não são dotados de total liberdade para normatizar, uma vez que devem estar de acordo com o bloco da constitucionalidade e com os princípios gerais de direito. Assim, não se pode considerar que os regulamentos autônomos estariam fora de esfera de controle do ordenamento jurídico, já que estes seriam seus limites, ao invés de uma mera exigência de lei formal ${ }^{106}$.

Retornando à classificação das espécies de formalização do poder normativo indicada por JOSÉ DOS SANTOS CARVALHO FILHO, existiriam ainda, além dos regulamentos, os atos de regulamentação de segundo grau. Estes seriam atos subordinados aos regulamentos, também responsáveis por realizar uma concreção, detalhando assim matérias abordadas por atos de regulamentação de primeiro grau, como instruções e resoluções. No entanto, o autor faz uma importante observação, ao afirmar que o que mais importa é a natureza do ato regulamentador, e não sua nomenclatura. Desta forma, sendo o ato normativo e concretizador de uma lei, este será ato regulamentar de primeiro grau, independentemente de sua nomenclatura ${ }^{107}$. Ainda, é

\footnotetext{
${ }^{104}$ BINENBOJM, Gustavo. Op. cit. p. 170-171.

105 ARAGÃO, Alexandre Santos de. A Concepção Pós-Positivista do Princípio da Legalidade, in Revista de Direito Administrativo, v. 256. Importante ressaltar novamente, a diferença, já abordada entre a noção de bloco de legalidade para Alexandre Santos de Aragão e aquela formulada por Hauriou.

${ }^{106}$ CANOTILHO, J. J. Gomes. Op. cit. p. 838.

${ }^{107}$ CARVALHO FILHO, José dos Santos. Op. cit. p. 54.
} 
fundamental lembrar que as considerações acerca da dependência à lei e dos limites impostos aos regulamentos, são também aplicáveis aos atos de regulamentação de segundo grau, como assim afirmou CELSO ANTÔNIO BANDEIRA DE MELLO ${ }^{108}$.

Isto posto, concluímos às análises acerca do princípio da legalidade e sua atual releitura, consubstanciada no princípio da juridicidade. Desta forma, e após o exame acerca dos dois níveis fundamentais de fontes do Direito subordinados à Constituição, faz-se necessário que se investigue o caso específico deste trabalho, qual seja, a atribuição normativa do Conselho Nacional de Saúde na questão das pesquisas científicas envolvendo seres humanos.

${ }^{108}$ MELLO, Celso Antônio Bandeira de. Op. cit. p. 365-366. 


\section{CAPÍTULO III - O CONSELHO NACIONAL DE SAÚDE}

O objetivo do presente Capítulo será realizar um exame acerca do Conselho Nacional de Saúde. Para isso, será procedido um breve histórico sobre o desenvolvimento deste órgão, do qual seguirá uma abordagem acerca de seus aspectos essenciais, a saber, sua atribuição, método de tomada de decisões, composição e estrutura organizacional. Por ser de profunda relevância para este estudo, serão também examinadas em tópico especial as Comissões do CNS, e ainda, a Comissão Nacional de Ética em Pesquisa.

\section{I - Breve histórico}

Antes de chegarmos à atual conjuntura do Conselho Nacional de Saúde, é imprescindível que se investigue o histórico de seu desenvolvimento, vislumbrado em três fases distintas até chegarmos à atual, como defendido por Frederico Augusto Barbosa da Silva e Luiz EduARdo DE LaCerda ABREU ${ }^{109}$.

A primeira destas fases consiste no período de 1954 a 1969, não obstante sua origem estar prevista na Lei $\mathrm{n}^{\circ} 378$, de 1937. A Lei retromencionada foi responsável por promover alterações no Ministério da Educação e Saúde Pública, no entanto, a regulamentação do Conselho Nacional de Saúde só ocorreu anos mais tarde, em 1954, pelo Decreto $\mathrm{n}^{\circ}$ 34.347. O Decreto estabelecia a finalidade do Conselho, qual seja, "assistir ao Ministro de Estado na determinação das bases gerais dos programas de proteção à saúde.” e, em seu artigo $2^{\circ}$ a composição dele, formado por 17 membros. Posteriormente,

\footnotetext{
${ }^{109}$ SILVA, Frederico Augusto Barbosa da. \& ABREU, Luiz Eduardo de Lacerda. "Saúde: Capacidade de Luta"- A experiência do Conselho Nacional de Saúde. Instituto de Pesquisa Econômica Aplicada, 2002. p. 43-53.
} 
sobreveio o Decreto no 45.913 de 1959, responsável por ampliar a composição do Conselho, passando este a contar com 24 membros. Nesse primeiro momento a composição do Conselho seria alterada ainda em outras três ocasiões, a primeira, através do Decreto $n^{\circ} 47.793$, em 1960. A segunda alteração ocorreu em 05/04/1962, através do Decreto $n^{\circ} 847$, de 5 de abril de 1962, responsável por revogar os atos normativos anteriores. Ademais, estabeleceu em seus artigos $5^{\circ}$ e $6^{\circ}$, que caberia ao Conselho cooperar com o Ministro de Estado e Saúde, seu presidente, no estudo dos assuntos atinentes. A terceira e última mudança ocorrida neste primeiro período foi a sucedida pelo Decreto $\mathrm{n}^{\circ}$ 55.242, de 1964, responsável por reestruturar o Conselho Nacional de Saúde. A modificação consistiu em uma redução do quadro de membros e definição de funções de forma mais abrangente, em seu artigo $2^{\circ}$ 110

O resultado deste primeiro momento foi um Conselho formado por membros da administração superior, de instituições médicas e expoentes da área de saúde, escolhidos pelo Poder Executivo, desprovido de estrutura burocrática, como destacado por SILVA e ABREU ${ }^{111}$. Tal composição retrata a finalidade do órgão em tela neste período, de mero órgão consultivo.

A segunda fase consiste em um momento importante para os membros do Conselho, pois, com a edição do Decreto 67.300, de 1970, muito além da ampliação do quadro de participantes, foi instituída uma estrutura burocrática estável. Ainda neste período sobreveio a Lei $n^{\circ}$ 6.229, de 17/06/1975, que constituiu o Sistema Nacional de Saúde, responsável por modificar o "ambiente institucional no qual o CNS estava inserido" ${ }^{112}$. No ano seguinte, foi editado o Decreto $\mathrm{n}^{\mathrm{o}}$ 79.056, com o condão de promover uma reestruturação do Ministério da Saúde. Dentre as mudanças, o Conselho

\footnotetext{
${ }^{110}$ Ibid. p. 43-47.

${ }^{111}$ Ibid. p. 52 .

${ }^{112}$ Ibid. p. 48 .
} 
Nacional de Saúde passou a ser considerado como um órgão pertencente à estrutura básica do Ministério, com alteração de sua estrutura e finalidade, consistente em "examinar e propor soluções para problemas concernentes à promoção, proteção e recuperação da saúde e elaborar normas por meio de suas câmaras técnicas, sobre assuntos específicos a serem encaminhados à apreciação do ministro de Estado", como definido em seu artigo $8^{\circ}$. Torna-se claro que as atribuições do Conselho sofreram amplificação, uma vez que, além da atribuição consultiva, passou a existir uma feição normativa, ainda que limitada.

Ainda sobre este período, remontamos ao desenvolvimento do Movimento da Reforma Sanitária, no qual os anseios por mudanças na área da saúde foram evidenciados, com o clamor popular por uma nova política marcada pela participação popular e acesso igualitário a serviços. As propostas deste "movimento sanitário" provinham dos princípios estabelecidos na Declaração dos Cuidados Primários de Saúde e sua ascensão, nos anos 1980 e 1990, teve ligação com período de redemocratização do Brasil, no qual a manifestação destes grupos foi favorecida ${ }^{113}$.

A VIII Conferência Nacional de Saúde representou o marco do ingresso da sociedade civil nas políticas de saúde e o momento no qual os clamores políticos pela universalização e participação popular, mediante democratização do aparato estatal ganharam força, culminando em seu relatório final. Como esperado, tal relatório apresentou de forma fiel o discutido na Conferência, prevendo ainda a criação de Conselhos de Saúde em âmbito local, municipal, regional e estadual, todos compostos por representantes da sociedade civil ${ }^{114}$.

\footnotetext{
113 CORTÊS, Soraya Maria Vargas. Conselhos e Conferências de Saúde: papel institucional e mudança nas relações entre Estado e sociedade. In Participação, Democracia e Saúde/ Sonia Fleury e Lenaura de Vasconcelos Costa Lobato (organizadoras) - Rio de Janeiro: Cebes, 2009. P. 109.

${ }^{114}$ SCHEVIBISKI, Renata S.. Regras Institucionais e Processo Decisório de Politicas Públicas: Uma análise sobre o Conselho Nacional de Saúde (1990-2006). São Paulo, 2007. 130 fls. Dissertação em Programa de Pós-Graduação, Faculdade de Filosofia, Letras e Ciências Humanas, Universidade de São Paulo. Ver também: CONFERÊNCIA NACIONAL DE SAÚDE, 8, Brasília, 1986. Anais. Ministério
} 
Após a Conferência, sobreveio a criação do Sistema Unificado e Descentralizado da Saúde (SUDS), responsável por imprimir maior racionalidade à política de saúde, com uma integração das diversas áreas de atuação neste sistema ${ }^{115}$. Suas diretrizes, quais sejam, a universalização dos serviços de saúde, a regionalização de tais serviços, entre outros, foram responsáveis por fundamentar o futuro desenvolvimento do Sistema Único de Saúde (SUS), na futura Constituição de 1988. Ainda como consequência da Conferência, temos a criação da Comissão Nacional de Reforma Sanitária, instalada em 1986, considerada por alguns autores como a precursora do novo Conselho Nacional de Saúde. Tal Comissão, composta por representantes da sociedade e do governo, tinha o objetivo de analisar os problemas do atual sistema de saúde e propor mudanças, representando mais um instrumento de democratização da saúde no Brasil ${ }^{116}$.

Assim alcançamos a terceira fase do Conselho, iniciada com a edição do Decreto $\mathrm{n}^{\mathrm{o}}$ 93.933, de 1987. O Decreto retromencionado reafirmou ser o Conselho um "órgão de deliberação coletiva", com a finalidade de auxiliar o Ministro da Saúde na implantação e execução da Política Nacional de Saúde. ${ }^{117}$ Dessa forma foram estabelecidas as bases para a instituição do sistema na Constituição Federal de 1988, com previsão em seus artigos 196 a 200 acerca da política de saúde no Brasil. Em 1990, sobreveio o Decreto n ${ }^{0} 99.438$, de

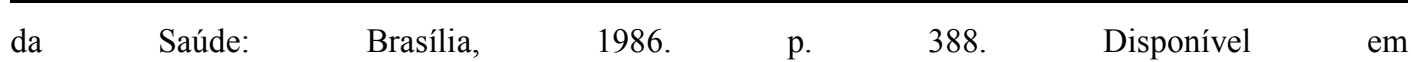
$<$ http://bvsms.saude.gov.br/bvs/publicacoes/0219VIIIcns.pdf>. Acesso em 22 de out. 2012.

115 COHN, Amelia. O Sistema Unificado e Descentralizado da Saúde: descentralização ou desconcentração? $\quad$ P. $\quad 56.5$ Disponível $<$ http://www.cedec.org.br/files_pdf/Osistemaunificadoedescentralizadodesaude.pdf $>$. Acesso em 15 out. 2012.

${ }^{116}$ CORTES, Soraya Vargas. Sistema Único de Saúde: espaços decisórios e a arena política de saúde. Cad. Saúde Pública, Rio de Janeiro, v. 25, n. 7, Julho 2009.

117 Assim dispôs o art. $1^{\circ}$ do Decreto 93.933, de 14 de janeiro de 1987. Ademais, acerca das suas competências, estabeleceu o artigo $2^{\circ}$ : “Art. $2^{\circ}$ - Compete ao Conselho Nacional de Saúde: I -exercer atuação normativa nas áreas concernentes à promoção, proteção e recuperação da saúde; II -assessorar o Ministro de Estado da Saúde na implantação e desenvolvimento da Política Nacional de Saúde; III pronunciar-se sobre matérias que, por força de disposições legais ou regulamentares, devam ser submetidas à sua apreciação; IV - opinar, quando solicitado, sobre projetos de lei em tramitação no Congresso Nacional que versem matéria de saúde e saneamento"
} 
07/08/1990, confirmando o "papel do CNS de formulação da estratégia e controle da execução da Política Nacional de Saúde" ${ }^{118}$. O Decreto foi também responsável por alterar a composição do Conselho, com recepção de diversos segmentos da sociedade, previsto em seu artigo $2^{\circ}$. Foi ainda editada a Lei $\mathrm{n}^{\circ} 8.080$, de 1990, responsável por instituir o SUS e estabelecer a forma de gestão do SUS com a participação da sociedade, dispondo sobre a criação de comissões subordinadas ao Conselho, com objetivo de articular políticas e programas de saúde. Ainda, foi atribuída ao CNS a competência de estatuir diretrizes para desenvolvimento dos planos de saúde ${ }^{119}$.

Assim foi possível chegar ao novo Conselho Nacional de Saúde, previsto no artigo $1^{\circ}, \S 2^{\circ}$ da Lei $8.142 / 90$, composto por representantes do governo, da sociedade civil, além de profissionais da saúde e prestadores de serviço. Suas atribuições foram de formular estratégias e controlar a execução da política de saúde no país, até mesmo as questões financeiras do sistema, das quais se retira a importância política da instituição no momento de sua criação ${ }^{120}$. A partir da compreensão de que os problemas da saúde não seriam somente técnicos, mas também políticos, e mais, da ideia de Estado na sociedade, ou seja, com áreas adequadas para representação e debate político, foi possível desenvolver o novo Conselho Nacional de Saúde ${ }^{121}$. Dessa forma, a terceira fase pela qual passou o CNS representa a vitória da voz popular, culminando em um órgão de composição paritária de diversos setores da sociedade. O órgão deixou para

\footnotetext{
118 SILVA, Frederico Augusto Barbosa da. \& ABREU, Luiz Eduardo de Lacerda. Op. Cit. p. 50.

${ }^{119}$ Ibid. p. 51

${ }^{120}$ Assim dispõe o $\S 2^{\circ}$ do artigo $1^{\circ}$ da Lei 8.142/1990: “§ $2^{\circ}$ O Conselho de Saúde, em caráter permanente e deliberativo, órgão colegiado composto por representantes do governo, prestadores de serviço, profissionais de saúde e usuários, atua na formulação de estratégias e no controle da execução da política de saúde na instância correspondente, inclusive nos aspectos econômicos e financeiros, cujas decisões serão homologadas pelo chefe do poder legalmente constituído em cada esfera do governo."

${ }^{121}$ SILVA, Frederico Augusto Barbosa da. \& ABREU, Luiz Eduardo de Lacerda. Op. Cit. p. 53.
} 
trás sua atribuição meramente consultiva, para adotar uma função deliberativa, propositiva e normativa, tamanha sua importância ${ }^{122}$.

\section{II - Composição do Conselho}

De forma a solidificar os anseios populares pela existência concreta de participação popular na tomada de decisões do setor público, a composição do CNS foi definida privilegiando a representação paritária da sociedade. Por este motivo, dispõe a Lei $n^{o}$ 8.142/90, que será composto por usuários, representantes do governo, prestadores de serviço e profissionais da saúde. A representação destes usuários, de acordo com a lei, deverá ser paritária em relação ao conjunto dos demais segmentos. Outrossim, a lei retromencionada estabelece que tanto o Conselho Nacional de Secretários de Saúde (Conass) quanto o Conselho Nacional de Secretários Municipais de Saúde (Conasems) serão representados no $\mathrm{CNS}$, sendo ele responsável por organizar-se em regimento próprio ${ }^{123}$.

Em 11 de julho de 2006, foi editado o Decreto $n^{\circ} 5.839$, dispondo sobre a organização, atribuição e o processo eleitoral do CNS. Deste modo, em seus incisos I e II do artigo $3^{\circ}$, definiu que sua representação seria formada por:

"I - cinqüenta por cento de representantes de entidades e dos movimentos sociais de usuários do SUS; e

\footnotetext{
${ }^{122}$ Ibid. p. 52.

${ }^{123}$ Assim dispõe o artigo $1^{\circ}, \S \S 2^{\circ}$ a $5^{\circ}$ da Lei 8.142/1990:“ $§ 2^{\circ}$ O Conselho de Saúde, em caráter permanente e deliberativo, órgão colegiado composto por representantes do governo, prestadores de serviço, profissionais de saúde e usuários, atua na formulação de estratégias e no controle da execução da política de saúde na instância correspondente, inclusive nos aspectos econômicos e financeiros, cujas decisões serão homologadas pelo chefe do poder legalmente constituído em cada esfera do governo. $\S 3^{\circ} \mathrm{O}$ Conselho Nacional de Secretários de Saúde (Conass) e o Conselho Nacional de Secretários Municipais de Saúde (Conasems) terão representação no Conselho Nacional de Saúde. § $4^{\circ}$ A representação dos usuários nos Conselhos de Saúde e Conferências será paritária em relação ao conjunto dos demais segmentos. $\S 5^{\circ}$ As Conferências de Saúde e os Conselhos de Saúde terão sua organização e normas de funcionamento definidas em regimento próprio, aprovadas pelo respectivo conselho."
} 
II - cinqüenta por cento de representantes de entidades de profissionais de saúde, incluída a comunidade científica da área de saúde, de representantes do governo, de entidades de prestadores de serviços de saúde, do Conselho Nacional de Secretários de Saúde CONASS, do Conselho Nacional de Secretários Municipais de Saúde - CONASEMS e de entidades empresariais com atividade na área de saúde.”

Percebe-se, desta maneira, a preocupação com a representação paritária de representantes de usuários quando comparado ao número de representantes dos demais segmentos presentes no Conselho, em atendimento à diretriz constitucional de participação da comunidade no Sistema Único de Saúde prevista no art. 198, inciso III da Carta Magna. Esta forma de representação da sociedade por entidades e movimentos sociais de usuários possui ligação direta com a legitimidade dessas organizações em promover a defesa do pluralismo de interesses de grupos sociais que permaneceram, durante muito tempo, alheios a qualquer processo de decisão política ${ }^{124}$. Ademais, esta é uma das razões de uma possível legitimidade democrática do Conselho, que será abordada posteriormente.

Além disso, sobre a composição de que trata o inciso II do artigo $3^{\circ}$, acima, determina o $§ 1^{\circ}$ do dispositivo, que deverão ser respeitados os seguintes números:

"I - vinte e cinco por cento de representantes de entidades de profissionais de saúde, incluída a comunidade científica da área de saúde;

II - vinte e cinco por cento de representantes distribuídos da seguinte forma:

a) seis membros representantes do Governo Federal;

b) um membro representante do CONASS;

c) um membro representante do CONASEMS;

d) dois membros representantes de entidades de prestadores de serviços de saúde; e

\footnotetext{
${ }^{124}$ LUCHMANN, Lígia Helena Hahn. Participação e representação nos conselhos gestores e no orçamento participativo. Cad. CRH, Salvador, v. 21, n. 52, Abr. 2008. Disponível em $<$ http://www.scielo.br/scielo.php?script=sci_arttext\&pid=S010349792008000100007\&lng=en\&nrm=i so>. Acessado em 23 Outubro de 2012.
} 
e) dois membros representantes de entidades empresariais com atividades na área de saúde."

A composição prevista nos incisos acima são indícios de decisões mais técnicas, uma vez que, na formulação e desenvolvimento de suas atividades, o Conselho conta com a contribuição de experts da saúde e representantes do governo. Neste momento, a discricionariedade técnica da atuação do CNS, tópico a ser abordado em momento posterior, vem à tona ${ }^{125}$.

$\mathrm{O} \S 2^{\circ}$ do artigo $3^{\circ}$ determina que os membros representantes do CONASS e CONASEMS serão indicados pelos presidentes de sua respectiva entidade ${ }^{126}$. Já em seu $\$ 4^{\circ}$, determina-se que será realizado processo eleitoral, que será abordado mais adiante, a cada três anos, para escolha das "entidades e dos movimentos sociais de usuários do SUS, das entidades de profissionais de saúde e da comunidade científica da área de saúde, das entidades de prestadores de serviços de saúde e das entidades empresariais com atividades na área de saúde que indicarão seus representantes para compor o CNS".

Ademais, para que seja possível sua participação no processo eleitoral mencionado, tais entidades devem ter, no mínimo, dois anos de existência comprovada, nos termos do parágrafo único, do artigo $4^{\mathrm{o}}{ }^{127}$.

\footnotetext{
${ }^{125}$ Sobre a discricionariedade técnica, cabe incluir definição de Vicenzo Cerulli Irelli: “ nos casos em que a lei prescreve à Administração uma atividade de aclaramento da realidade tecnicamente complexa que importa no emprego de disciplinas especializadas, ou mesmo nos casos em que esse aclaramento for necessário ao exercício do poder, esta doutrina (criticável, porém consolidada) considera atribuído um verdadeiro e adequado poder discricionário (de conteúdo técnico)" IRELLI, Vicenzo Cerulli. Notte sulla discrezionalità amministrativa, in Le Transformazioni del Diritto Amministrativo. Milão, Giuffrè, 1995. P. 54. Apud. MOREIRA NETO, Diogo de Figueiredo. Mutações do Direito Administrativo. Rio de Janeiro: Renovar, 2000. p. 169.

${ }^{126}$ Art. $3^{\circ}, \S 2^{\circ}$ do Decreto $n^{\circ} 5.839 / 2006$ : “\$ $2^{2}$ Os representantes de que tratam as alíneas "b" à "e" do inciso II do $\S 1^{\circ}$ serão indicados respectivamente pelos presidentes das entidades representadas.".

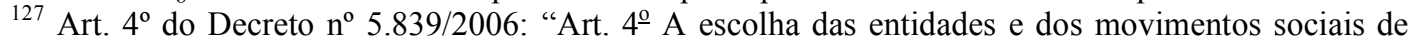
usuários do SUS, das entidades de profissionais de saúde e da comunidade científica da área de saúde, das entidades de prestadores de serviços de saúde e das entidades empresariais com atividades na área de saúde que indicarão seus representantes para compor o CNS, será feita por meio de processo eleitoral, a ser realizado a cada três anos, contados a partir da primeira eleição. Parágrafo único. Somente poderão participar do processo eleitoral, como eleitor ou candidato, as entidades de que tratam os incisos I a IV do art. 5ํㅜ que tenham, no mínimo, dois anos de comprovada existência."
} 
O preciosismo do Decreto $n^{\circ} 5.839 / 2006$ incluiu ainda a definição de cada um dos grupos que visa à representação no Conselho, em seu artigo $5^{\circ}$, quais sejam:

"Art. $5^{\circ}$ Para efeito de aplicação deste Decreto, definem-se como:

I - entidades e movimentos sociais nacionais de usuários do SUS - aqueles que tenham atuação e representação em, pelo menos, um terço das unidades da Federação e três regiões geográficas do País;

II - entidades nacionais de profissionais de saúde, incluindo a comunidade científica aquelas que tenham atuação e representação em, pelo menos, um terço das unidades da Federação e três regiões geográficas do País, vedada a participação de entidades de representantes de especialidades profissionais;

III - entidades nacionais de prestadores de serviços de saúde - aquelas que congreguem hospitais, estabelecimentos e serviços de saúde privados, com ou sem fins lucrativos, e que tenham atuação e representação em, pelo menos, um terço das unidades da Federação e três regiões geográficas do País; e

IV - entidades nacionais empresariais com atividades na área da saúde - as confederações nacionais da indústria, do comércio, da agricultura e do transporte que tenham atuação e representação em, pelo menos, um terço das unidades da Federação e três regiões geográficas do País.

Parágrafo único. Consideram-se colaboradores do CNS as universidades e as demais entidades de âmbito nacional, representativas de profissionais e usuários de serviços de saúde."

Previu também que seus membros teriam mandato de três anos, sendo permitida uma reeleição, nos moldes do artigo $7^{\circ}$ do referido Decreto. Logicamente, e segundo disposto no parágrafo único do artigo $7^{\circ}$, a reeleição só será cabível quando a entidade a qual pertence o membro tiver sido previamente reeleita ${ }^{128}$. Além disso, de forma contrária ao que foi inicialmente

\footnotetext{
128 “Art. 7ํㅜ O mandato dos membros do CNS será de três anos, permitida apenas uma recondução. Parágrafo único. A recondução de que trata este artigo somente se aplica aos membros das entidades e dos movimentos sociais eleitos cujas entidades tiverem sido reeleitas."
} 
previsto para a estrutura do Conselho, ou seja, que sua presidência seria ocupada pelo Ministro de Estado da Saúde, atualmente, ocorre eleição entre os membros titulares para preenchimento da vaga, conforme dispõe o Decreto em seu artigo $6^{\text {o }}{ }^{129}$.

Respeitada a eleição das entidades prevista no artigo $4^{\circ}$ e as disposições $\operatorname{dos} \S \S 1^{\circ}$ e $2^{\circ}$ do artigo $3^{\circ}$, o Decreto $n^{o} 5.839 / 2006$ determina que pertence ao Ministro de Estado e Saúde a competência para designar os representantes do Governo Federal, do CONASS, do CONASEMS, e também das entidades e movimentos sociais ${ }^{130}$. Previu-se, ademais, em seu artigo 12 , que poderão ser convidados técnicos, autoridades ou cientistas, independentemente de sua nacionalidade, para enriquecerem os estudos ou participarem de comissões do Conselho ${ }^{131}$.

O processo eleitoral, referido acima, que culmina na eleição dos membros do Conselho, previsto no caput do art. $8^{\circ}$ do Decreto $n^{\circ} 5.839 / 2006$, é realizado nos moldes de Regimento Eleitoral aprovado pelo plenário do CNS em forma de Resolução, atualmente consubstanciada na Resolução $n^{\circ} 457$, de 09/08/2012 ${ }^{132}$. Nos moldes da Resolução, a eleição entre os anos de 2012 e 2015 será coordenada por uma comissão formada por doze membros, sendo estes indicados por seus respectivos segmentos, quais sejam, usuários,

\footnotetext{
129 “Art. 60 O Presidente do CNS será eleito, entre os conselheiros titulares, em escrutínio secreto, na reunião em que tomarem posse os novos membros, votantes somente os membros titulares."

130 “Art. 9ํㅜㄹ Fica delegada competência ao Ministro de Estado da Saúde para designar os representantes do Governo Federal, do CONASS, do CONASEMS, das entidades e dos movimentos sociais eleitos, observadas as indicações de que tratam os $\S \S 1^{\circ}$ e $2^{-}$do art. $3^{\circ}$ e o resultado do processo eleitoral previsto no art. 4⿳.",

131 “Art. 12. O CNS poderá convidar entidades, autoridades, cientistas e técnicos nacionais ou estrangeiros, para colaborarem em estudos ou participarem de comissões instituídas no âmbito do CNS, sob a coordenação de um de seus membros."

132 "Art. $8^{\mathrm{o}} \mathrm{O}$ processo eleitoral a que se refere o art. $4^{\mathrm{o}}$, para a escolha das entidades que indicarão representantes em substituição aos atuais membros do CNS, será realizado em até noventa dias, contados da publicação deste Decreto, em conformidade com o regimento eleitoral a ser aprovado pelo plenário do CNS, homologado pelo Ministro de Estado da Saúde e publicado no Diário Oficial da União em forma de resolução. Parágrafo único. Concluída a eleição referida no caput e designados os novos representantes do CNS, caberá ao Ministro de Estado da Saúde convocar e presidir a reunião em que tomarão posse os conselheiros e em que se realizará a eleição do Presidente do Conselho.”
} 
profissionais da saúde e representantes do governo/prestadores de serviços de saúde. O segmento dos usuários conta com a metade dos componentes desta comissão, cabendo lembrar ainda que todos eles devem ser aprovados pelo Conselho, na forma do art. $2^{\circ}$ do Regimento Eleitoral ${ }^{133}$. Dentre as atribuições desta Comissão constam o dever de conduzir o processo eleitoral, apreciar e decidir recursos, indicar relator para acompanhar discussões nas plenárias dos segmentos, entre outros, todos definidos nos incisos do art. $3^{\circ}$ do Regimento Eleitoral ${ }^{134}$. Na eleição são abertas vagas para vinte e quatro representantes titulares de entidades e dos movimentos sociais nacionais de usuários do SUS, doze representantes titulares das entidades nacionais de profissionais de saúde, incluída a comunidade científica da área de saúde, dois representantes titulares das entidades nacionais de prestadores de serviços de saúde e dois representantes titulares das entidades empresariais nacionais com atividades na área de saúde, além das vagas para primeiro e segundo suplentes de cada um dos representantes titulares, de acordo com o artigo $5^{\circ}$ do referido regimento

\footnotetext{
133 “Art. $2^{\circ}$ A eleição será coordenada por uma Comissão Eleitoral composta de 12 (doze) membros indicados pelos respectivos segmentos e aprovada pelo Conselho Nacional de Saúde com a seguinte composição: I - 6 (seis) representantes do segmento dos usuários; II - 3 (três) representantes do segmento dos profissionais de saúde; e III - 3 (três) representantes do segmento do governo/prestadores de serviços de saúde $; \S 1^{\circ}$ As entidades e os movimentos sociais que indicarem pessoas para compor a Comissão Eleitoral serão elegíveis. $\S 2^{\circ}$ Constituída a Comissão Eleitoral, a mesma será divulgada na página eletrônica do Conselho Nacional de Saúde e afixada na SecretariaExecutiva do referido Conselho. $\S 3^{\circ}$ A Comissão Eleitoral terá um presidente, um vice-presidente, um secretário e um secretário adjunto, que serão escolhidos entre os seus membros na primeira reunião após sua constituição."

134 “Art. $3^{\circ}$ Compete à Comissão Eleitoral: I - conduzir sob sua supervisão o processo eleitoral e deliberar sobre tudo que se fizer necessário para o seu andamento; II - requisitar ao Conselho Nacional de Saúde todos os recursos necessários para a realização do processo eleitoral; III - instruir, qualificar, apreciar e decidir recursos, decisões do presidente relativas a registro de candidatura e outros assuntos ao pleito eleitoral; IV - indicar e instalar as Mesas Eleitorais em número suficiente com a função de disciplinar, organizar, receber e apurar votos; V - proclamar o resultado eleitoral; VI - apresentar ao Conselho Nacional de Saude relatório do resultado do pleito, bem como observações que possam contribuir para o aperfeiçoamento do processo eleitoral, no prazo de até 30 (trinta) dias após a proclamação do resultado; VII - indicar a mesa coordenadora das plenárias dos segmentos composta por 1 (um) coordenador, 1 (um) secretário e 1(um) relator; e VIII - indicar 1 (um) relator para acompanhar as discussões dos fóruns próprios ou grupos nas plenárias dos segmentos.”
} 
135. A efetiva eleição ocorre através de Plenárias dos Segmentos, na qual a primeira chamada deve obedecer o quórum de metade mais um do total dos delegados credenciados ${ }^{136}$. Em hipótese de consenso, ocorre a aclamação dos resultados, de acordo com o art. 10, caput, da Resolução ${ }^{137}$. Já em hipótese de inexistência de consenso, ocorre eleição por voto secreto para preenchimento do restante da vagas. É válido lembrar que a apuração dos votos é realizada por Mesas designadas pela Comissão Eleitoral que sofrem controle, uma vez que há a possibilidade de indicação de fiscais, pelas entidades sociais, para acompanhar o trabalho, de acordo com o $\$ 3^{\circ}$ do art. 11 da Resolução 457 de 2012. Os fiscais indicados tem competência para apresentar recursos, e caso não seja atingida a porcentagem mínima de $10 \%$ de votos ou em caso de empate, deve ocorrer nova eleição, nos moldes dos $\S \S 4^{\circ}$ a $8^{\circ}$ do art. 11

\footnotetext{
${ }^{135}$ Art. $5^{\circ}$ As vagas dos representantes de entidades e dos movimentos sociais nacionais de usuários do SUS, das entidades nacionais de profissionais de saúde, incluída a comunidade científica da área de saúde, das entidades nacionais de prestadores de serviços de saúde e das entidades empresariais nacionais com atividades na área de saúde, a serem eleitos para participarem do Conselho Nacional de Saúde, conforme previsto no art. $4^{\circ}$ do Decreto $n^{\circ} 5.839$, de 11 de julho de 2006 , são as seguintes: I - 24 (vinte e quatro) vagas para representantes titulares e 48 (quarenta e oito) vagas para representantes primeiro e segundo suplentes para as entidades e os movimentos nacionais de usuários do SUS;II - 12 (doze) vagas para representantes titulares e 24 (vinte e quatro) vagas para representantes primeiro e segundo suplentes para as entidades nacionais de profissionais de saúde, incluída a comunidade científica da área de saúde; III - 2 (duas) vagas para representantes titulares e 4 (quatro) vagas para representantes primeiro e segundo suplentes para as entidades nacionais de prestadores de serviços de saúde; e IV - 2 (duas) vagas para representantes titulares e 4 (quatro) vagas para representantes primeiro e segundo suplentes para as entidades empresariais nacionais com atividades na área da saúde. (...)”
}

136 "Art. $9^{\circ}$ A eleição para preenchimento das vagas dos membros titulares no Conselho Nacional de Saúde das entidades e dos movimentos sociais de usuários do SUS, das entidades de profissionais de saúde, das entidades da comunidade científica da área de saúde, das entidades de prestadores de serviços de saúde, das entidades empresariais com atividades na área de saúde, bem como para preenchimento das suplências, dar-se-á por meio de Plenárias dos Segmentos, no dia 27 de novembro de 2012, no horário das 10 horas às 13 horas, em local a ser definido pela Comissão Eleitoral, e, se necessário, em turno único, por meio de voto secreto, na mesma data, das 14 horas às 18 horas. $\S 1^{\circ} \mathrm{O}$ credenciamento dos delegados inscritos representantes das entidades e dos movimentos sociais será na mesma data da eleição, das $8 \mathrm{~h} 30 \mathrm{~min}$ às $9 \mathrm{~h} 30 \mathrm{~min}$, impreterivelmente. $\$ 2^{\circ} \mathrm{O}$ delegado credenciado receberá um crachá de identificação que lhe dará direito de acesso ao local de votação, não sendo permitida a substituição ou reposição de crachá. $3^{\circ}$ A Comissão Eleitoral fará a primeira chamada para as Plenárias dos Segmentos às 10 horas com quorum de metade mais um dos delegados credenciados e, em segunda chamada, às $10 \mathrm{~h} 30 \mathrm{~min}$, com qualquer número, iniciando-se as Plenárias neste horário e encerrando-se, no máximo, às 13 horas.".

137 “Art. 10 Havendo consenso para escolha dos representantes titulares e suplentes durante as Plenárias dos Segmentos, a Eleição se dará por aclamação, mediante apresentação da Ata da Plenária assinada pelos representantes dos segmentos participantes do processo. Parágrafo único. A Plenária do Segmento poderá utilizar o resultado do processo de discussão em fóruns próprios ou em grupos, de acordo com suas especificidades, devendo, todavia, os resultados dos fóruns ou grupos serem submetidos à Plenária dos Segmentos." 
retromencionado ${ }^{138}$. A tais fiscais é atribuída também a tarefa de acompanhar a apuração dos votos, em obediência ao estabelecido no caput do art. 16 da Resolução. A Mesa Apuradora, por sua vez, tem o dever de se pronunciar acerca de possíveis impugnações e demais ocorrências, e, em havendo discordância neste pronunciamento, é cabível interposição de recurso perante a Comissão Eleitoral, de acordo com os $\S \S 1^{\circ}$ e $3^{\circ}$ do artigo $16^{139}$. Deve-se ter em mente ademais que os critérios para escolha da entidade ou movimento social, em caso de empate, são a presença em maior número de Regiões Geográficas e/ou Unidades da Federação do País e o maior tempo de existência e funcionamento, nos moldes do artigo 17 da resolução 457 de $2012^{140}$.

O processo eleitoral tem seu fim com a proclamação do resultado pela Comissão Eleitoral e sua homologação, divulgação do Edital na página

\footnotetext{
138 “Art. 11 Não havendo consenso para a escolha das entidades ou dos movimentos sociais na Plenária do Segmento, a eleição se fará por voto secreto, no horário das 14 horas às 18 horas, cabendo à Comissão Eleitoral designar, antecipadamente, Mesas para recepção e apuração dos votos, formadas por 3 (três) membros, sendo 1 (um) Presidente, 1 (um) $1^{\circ}$ Secretário e 1 (um) $2^{\circ}$ Secretário. $\S 1^{\circ} \mathrm{A}$ Plenária do Segmento encaminhará para votação, conforme o caput deste artigo, somente as vagas não preenchidas, total ou parcialmente, no processo de votação por aclamação. $\S 2^{\circ}$ A entidade ou movimento social que obtiver o maior número de votos terá direito a indicar o representante titular, os representantes primeiro-suplentes e segundo-suplentes da sua própria entidade ou dentre as entidades que participaram do processo eleitoral $\S 3^{\circ}$ A votação dos segmentos poderá ser acompanhada e fiscalizada por fiscais indicados pelas entidades ou movimentos sociais que integrarem os segmentos, desde que os seus nomes sejam encaminhados à Comissão Eleitoral até 2 (dois) dias antes da realização da eleição e desde que não cause tumulto ao pleito. $\S 4^{\circ}$ Os fiscais poderão apresentar recursos em formulário próprio, a serem entregues ao Presidente da Mesa e consignados em Ata. $\S 5^{\circ}$ Após a análise dos recursos, quando houver, será iniciada a apuração dos votos. $\S 6^{\circ}$ Serão eleitas as entidades ou movimentos sociais que obtiverem no mínimo, $10 \%$ (dez por cento) dos votos do segmento no qual estejam concorrendo, respeitando-se o número de vagas de cada entidade ou movimento social no seu respectivo segmento. $\S 7^{\circ}$ No caso de não ser alcançada a porcentagem mínima de $10 \%$ (dez por cento) dos votos referida no $\S 6^{\circ}$, deverá haver uma nova votação imediatamente para preenchimento das vagas restantes. $\S 8^{\circ}$ Em caso de empate deverá haver uma nova votação imediatamente para preenchimento das vagas restantes."

139“Art. 16 A apuração dos votos será realizada e acompanhada pelos fiscais após o voto do último delegado credenciado. $\S 1^{\circ}$ Antes da abertura da urna, a Mesa Apuradora se pronunciará sobre os pedidos de impugnação e as ocorrências porventura constantes da Ata de Votação. $2^{\circ}$ Os pedidos de impugnação e de recursos concernentes à votação, que não tenham sido consignados na Ata de Votação, não serão considerados. $\$ 3^{\circ}$ Em caso de discordância de pronunciamento da Mesa Apuradora, caberá recurso à Comissão Eleitoral, procedendo-se normalmente à apuração, com o devido registro dos recursos."

140 "Art. 17 Em caso de empate, os critérios para a proclamação da entidade ou movimento social eleitos serão: a) existência da entidade ou do movimento social em maior número de Regiões Geográficas e/ou Unidades da Federação do País; e b) maior tempo de existência e funcionamento da entidade ou do movimento social."
} 
eletrônica do Conselho Nacional de Saúde e publicação no Diário Oficial da União, atendendo ao estabelecido nos artigos 18 e 19 da Resolução 457 e à exigência de publicidade aos atos da Administração Pública ${ }^{141}$.

Ademais, em consonância com todo o disposto no Decreto $\mathrm{n}^{\mathrm{o}}$ 5.839/2006, especialmente seu artigo 11, o Regimento Interno do CNS, aprovado pela Resolução n 407 de 12 de setembro de 2008, também dispõe sobre sua composição, em seus artigos $4^{\circ}$ a $6^{\circ}{ }^{142}$. No Regimento

141 "Art. 18 As Mesas Apuradoras comunicarão o resultado da eleição à Comissão Eleitoral que
proclamará as entidades e os movimentos sociais eleitos . Art. 19 Após homologado, o resultado final
da votação será divulgado na página eletrônica do Conselho Nacional de Saúde, por meio de Edital,
bem como publicado no Diário Oficial da União que será afixado na Secretaria-Executiva do Conselho
Nacional de Saúde, com a indicação das entidades e dos movimentos sociais eleitos para indicarem
seus representantes às vagas de membros do Conselho Nacional de Saúde, titulares e suplentes."
142 Art. 11 do Decreto $n^{\circ} 5.839 / 2006$ : "Art. 11 . A organização e o funcionamento do CNS serão
disciplinados em regimento interno, aprovado pelo plenário e homologado pelo Ministro de Estado da
Saúde." Previsão dos artigos $4^{\circ}$ a $6^{\circ}$ Regimento Interno, aprovado pela Resolução $n^{\circ} 407$, de 2008: Art. $4^{\circ} \mathrm{O}$ CNS é composto por quarenta e oito membros titulares, sendo: I - cinqüenta por cento de membros representantes de entidades e dos movimentos sociais de usuários do SUS, eleitos em processo eleitoral direto; e II - cinqüenta por cento de membros representantes de entidades de profissionais de saúde, incluída a comunidade científica da área de saúde, entidades de prestadores de serviços de saúde, entidades empresariais com atividade na área de saúde, todas eleitas em processo eleitoral direto, bem como de representantes do governo, Conselho Nacional de Secretários de Saúde CONASS e Conselho Nacional de Secretários Municipais de Saúde - CONASEMS, todos indicados pelos seus respectivos dirigentes. $\S 1^{\circ} \mathrm{O}$ percentual de que trata o inciso II deste artigo observará a seguinte distribuição: I - metade dos membros representantes de entidades de profissionais de saúde, incluída a comunidade científica da área de saúde; e II - metade dos membros representantes distribuídos da seguinte forma: a) seis membros representantes do Governo Federal; b) um membro representante do CONASS; c) um membro representante do CONASEMS; d) dois membros representantes de entidades de prestadores de serviços de saúde; e e) dois membros representantes de entidades empresariais com atividades na área de saúde. $\S 2^{\circ}$ Os membros titulares do CNS terão primeiros e segundos suplentes, indicados na forma deste Regimento. Art. $5^{\circ}$ A representação dos órgãos, das entidades e dos movimentos sociais inclui um membro titular e primeiro e segundo suplentes, vinculados, ainda que não sejam da mesma entidade ou órgão. Parágrafo único. Na presença do membro titular, o membro suplente não terá direito a voz e voto nas reuniões. Art. $6^{\circ}$ Os representantes indicados pelas entidades e pelos movimentos sociais dos usuários do SUS, pelas entidades de profissionais de saúde e comunidade científica, pelas entidades empresariais com atividades na área da saúde e pelas entidades dos prestadores de serviços de saúde, todas eleitas, terão o mandato de três anos, permitida apenas uma recondução. $\S 1^{\circ}$ Será dispensado, automaticamente, o conselheiro que deixar de comparecer a três reuniões consecutivas ou a seis reuniões intercaladas, sem justificativa, por escrito, no período de um ano civil. $\S 2^{\circ}$ As justificativas de ausências deverão ser apresentadas na Secretaria-Executiva do Conselho Nacional de Saúde até quarenta e oito horas úteis, após a reunião. $\S 3^{\circ} \mathrm{A}$ perda de mandato da representação de qualquer entidade ou movimento social será declarada pelo Plenário do CNS, por decisão da maioria simples dos seus membros, sendo a vaga assumida pelo membro primeiro suplente. $\S 4^{\circ}$ Fica a cargo das entidades ou dos movimentos sociais a indicação dos respectivos representantes para o exercício do mandato, bem como a sua substituição, a qualquer tempo, excetuando-se os casos previstos nos $\S 1^{\circ}$ e $3^{\circ}$ deste artigo. $\S 5^{\circ} \mathrm{A}$ recondução de que 
retromencionado, precisamente em seu art. 14, estão definidas as atribuições dos Conselheiros eleitos, dentre as quais destacamos a atribuição de estudar e apreciar as matérias que estiverem submetidas à análise do Conselho, até mesmo com assessoramento técnico e de apresentar Resoluções ou outras proposições sobre assuntos ligados à saúde ${ }^{143}$. Sobre esse ponto, cabe atentar para o fato de que, não obstante a Lei 8.142 de 1990 prever que cabe ao Conselho definir e aprovar seu regimento interno, as atribuições dos Conselheiros estão listadas apenas em seu próprio Regimento e não em dispositivo legal. No entanto, é importante lembrar também que tal Regimento foi homologado pelo Ministro de Estado, que demonstrou desta forma, sua concordância com tais normas de funcionamento e atribuições.

É fundamental ter em mente, quanto a este ponto, que o processo eleitoral abordado, responsável por permitir que os próprios membros do CNS definam sua composição, tal como a própria composição do Conselho, já vista, permitem que seja vislumbrada a existência de uma democracia participativa, na qual os próprios administrados participam das decisões a serem tomadas. Essa é uma das razões para uma possível defesa das atividades exercidas pelo Conselho, já que este seria uma instância com participação da sociedade. A conclusão a que se chega é de alto grau de legitimidade democrática, uma vez que, nas palavras de Diogo MoreIRA Neto, “os sistemas juspolíticos de alto

\footnotetext{
trata o caput deste artigo somente se aplica aos membros representantes das entidades ou dos movimentos sociais que tiverem sido reeleitos."

143 "Art. 14 São atribuições dos Conselheiros: I - zelar pelo pleno e total desenvolvimento das ações do CNS; II - estudar e relatar, nos prazos preestabelecidos, matérias que lhes forem distribuídas, podendo valer-se de assessoramento técnico e administrativo; III - apreciar as matérias submetidas ao CNS para votação; IV - apresentar Moções, Recomendações, Resoluções ou outras proposições sobre assuntos de interesse da saúde; V - requerer votação de matéria em regime de urgência; VI - acompanhar e verificar o funcionamento dos serviços de saúde no âmbito do SUS, dando ciência ao Plenário quando necessário; VII - apurar denúncias sobre matérias afetas ao CNS, apresentando relatório da missão, sem prejuízo das competências dos demais órgãos da Administração Pública, a exemplo do Departamento Nacional de Auditoria do SUS- DENASUS/MS; VIII - desempenhar outras atividades necessárias ao cumprimento de suas atribuições e do funcionamento do CNS; IX - pedir vistas em assuntos submetidos à análise do CNS, quando julgar necessário; e X - representar o CNS perante as instâncias e fóruns da sociedade e do governo quando for designado pelo Plenário."
} 
consenso maximizam a legitimidade e podem funcionar com baixo nível de coerção" 144 .

\section{III - Estrutura organizacional}

O Conselho tem sua estrutura constituída pelo Plenário, Mesa Diretora, Comissões, Grupos de Trabalho, Presidência e Secretaria-Executiva, atendendo ao disposto no artigo $7^{\circ}$ de seu Regimento Interno ${ }^{145}$. O Plenário, composto por quarenta e oito membros, traduz a instância última de deliberação das questões subordinadas ao crivo do Conselho, conforme art. $8^{\circ}$ do Regimento Interno ${ }^{146}$. Suas atribuições encontram-se listadas no art. 11 do Regimento Interno, do qual destacamos a competência para "aprovar normas sobre ética em pesquisas envolvendo seres humanos e outras questões no campo da bioética e acompanhar sua implementação" ${ }^{147}$. Ademais, cabe ao

${ }^{144}$ MOREIRA NETO, Diogo de Figueiredo. Legitimidade e Discricionariedade. Novas Reflexões sobre os Limites e Controle da Discricionariedade. $3^{\text {a }}$ Ed. Rio de Janeiro: Forense, 1998. p.7.

${ }^{145}$ “Art. $7^{\circ} \mathrm{O}$ CNS tem a seguinte organização: I - Plenário; II - Mesa Diretora; e III - Comissões. $\S 1^{\circ}$ O CNS poderá contar com Grupos de Trabalho, instituídos na forma deste Regimento, os quais fornecerão subsídios de ordem política, técnica, administrativa, econômico-financeira e jurídica, sem, contudo, integrar a composição do Conselho.§ $2^{\circ}$ O Conselho Nacional de Saúde conta, também, com uma Secretaria-Executiva como suporte técnico-administrativo às suas atribuições."

146 “Art. $8^{\circ}$ O Plenário do CNS é o fórum de deliberação plena e conclusiva, configurado por reuniões ordinárias e extraordinárias, de acordo com requisitos de funcionamento estabelecidos neste Regimento."

147 "Art. 11 Compete ao Plenário do CNS: I - dar operacionalidade às competências do CNS descritas no art. 10 deste Regimento; II - deliberar sobre os modelos de atenção à saúde da população e de gestão do SUS; III - definir prioridades, métodos e estratégias para a formação e educação permanente dos trabalhadores, gestores, prestadores de serviços e usuários do SUS; IV - aprovar a proposta setorial da saúde, no Plano Plurianual, Lei de Diretrizes Orçamentárias e no Orçamento Geral da União e participar da consolidação do Orçamento da Seguridade Social, após análise anual dos planos de metas, compatibilizando-a com os planos de metas previamente aprovados, observado o princípio do processo de planejamento e orçamento ascendente; V - a qualquer tempo, criar, modificar, suspender temporariamente as atividades e extinguir, Comissões Intersetoriais, integradas pelos ministérios, órgãos competentes e por entidades, instituições e movimentos nacionais representativos da sociedade civil e Grupos de Trabalho compostos por Conselheiros do CNS, por maioria qualificada de votos dos conselheiros; VI - deliberar sobre propostas de normas básicas nacionais para operacionalização do SUS;VII - estabelecer diretrizes gerais e aprovar parâmetros nacionais quanto à política de recursos humanos para a saúde; VIII - definir diretrizes e fiscalizar a movimentação e aplicação dos recursos financeiros do SUS, em âmbito federal, com base no cumprimento dos percentuais definidos na Resolução CNS n ${ }^{\circ} 322$, de 8 de maio de 2003, na Emenda Constitucional n ${ }^{\circ}$ 29, de 13 de setembro de 
Plenário eleger a Mesa Diretora dentre os Conselheiros titulares. Além dos Conselheiros eleitos, a Mesa Diretora é também composta pelo Presidente do Conselho e possui, entre outras, a atribuição de orientar os processos que virão a ser apreciados pelo Plenário e promover articulações com órgãos, instituições e conselhos de políticas públicas, conforme disposto no art. 12 do Regimento Interno ${ }^{148}$. No exercício de suas atribuições, devem respeitar os princípios

2000, e na legislação vigente sobre o tema; IX - aprovar a organização e as normas de funcionamento da Conferência Nacional de Saúde, reunida ordinariamente a cada quatro anos, e convocá-la extraordinariamente, se necessário, na forma prevista pela Lei $n^{\circ} 8.142$, de 28 de dezembro de 1990; X - incrementar e aperfeiçoar o relacionamento sistemático com os poderes constituídos, o Ministério Público, o Judiciário, o Congresso Nacional e a mídia, bem como com setores relevantes não representados no Conselho; XI - definir ações de integração com outros conselhos setoriais com o propósito de cooperação mútua e de estabelecimento de estratégias comuns para o fortalecimento do sistema de participação e controle social; XII - emitir pareceres quanto à criação de novos cursos de ensino superior na área de saúde, no que concerne à caracterização das necessidades sociais; XIII decidir sobre impasses ocorridos nos Conselhos Estaduais e Municipais de Saúde, e com relação aos Conselhos Municipais, após ouvido o Conselho Estadual correspondente, na condição de instância recursal; XIV - aprovar normas sobre ética em pesquisas envolvendo seres humanos e outras questões no campo da bioética e acompanhar sua implementação; XV - definir diretrizes gerais para a participação dos diversos provedores no SUS; XVI - regulamentar as especializações na área da saúde na forma de treinamento em serviço sob supervisão; XVII - aprovar a indicação do nome da Secretária-Executiva do CNS, bem como solicitar ao Ministro da Saúde a sua substituição diante de situações que a justifiquem, ambas por deliberação da maioria absoluta do Plenário do CNS; XVIII deliberar acerca de instruções e ações que favoreçam o exercício das atribuições legais dos Conselhos Estaduais e Municipais de Saúde; XIX - deliberar ações para divulgação do CNS nos meios próprios de comunicação social, sem prejuízo das normas estabelecidas pela Assessoria de Comunicação Social -ASCOM; XX - eleger o Presidente do CNS, bem como os demais membros da Mesa Diretora; XXI elaborar e aprovar o Regimento Eleitoral da eleição das entidades e dos movimentos sociais dos usuários do SUS, das entidades de profissionais de saúde e da comunidade científica da área de saúde, das entidades de prestadores de serviços de saúde e das entidades empresariais com atividades na área de saúde, no prazo de cento e vinte dias anteriores à data estabelecida para as eleições, de acordo com a Resolução CNS no 361, de 12 de julho de 2006; e XXII - aprovar representação junto ao Ministério Público quando as competências e decisões do Conselho forem desrespeitadas ou ocorrer ameaça de grave lesão à saúde pública, por maioria qualificada de votos: a) entende-se por maioria simples o número inteiro imediatamente superior à metade dos membros presentes; b) entende-se por maioria absoluta o número inteiro imediatamente superior à metade do total de membros do Conselho; e c) entende-se por maioria qualificada $2 / 3$ (dois terços) do total dos membros do Conselho."

148 “Art. 12 Compete à Mesa Diretora: I - articular, junto ao Poder Executivo, as condições necessárias para o pleno funcionamento do CNS, incluindo a execução do planejamento e o monitoramento das ações; II - promover articulações políticas com órgãos e instituições, internos e externos, com vistas a garantir a intersetorialidade do controle social e a articulação com outros conselhos de políticas públicas com o propósito de cooperação mútua e de estabelecimento de estratégias comuns para o fortalecimento da participação da sociedade na formulação, implementação e no controle das políticas públicas; III - elaborar e encaminhar ao Plenário do CNS relatórios mensais sucintos das suas atividades, assim como submeter, anualmente, ao Plenário, relatório de gestão; IV - responsabilizar-se pelo acompanhamento da execução orçamentária do CNS e sua prestação de contas ao Plenário; V - 
estabelecidos no artigo $9^{\circ}$ do Regimento referido, como democracia, transparência e equidade ${ }^{149}$.

Ao Plenário é também atribuída a competência para instituir Grupos de Trabalho, organismo temporário com atribuição de assessorar o próprio Plenário ou as Comissões. Os Grupos de Trabalhos são formados por Conselheiros, nos quais procura-se obedecer a uma representação de todos os segmentos presentes do CNS, que são responsáveis por prestar assessoria jurídica, política, administrativa e econômico-financeira, nos moldes do referido $\S 1^{\circ}$ do art. $7^{\circ}$, art. 53 e art. 54 do Regimento Interno. Importante lembrar ainda, que, para melhor execução de seu trabalho, os Conselheiros que participam dos Grupos de Trabalho poderão contar com ajuda de especialistas, na forma do art. 55 do Regimento Interno ${ }^{150}$.

responsabilizar-se pelo encaminhamento de todas as matérias para deliberação do CNS; VI - analisar o relatório de freqüência dos Conselheiros nas reuniões do CNS para deliberação do Plenário e demais providências regimentais; VII - decidir, quando necessário, pelo convite a especialistas, visando a esclarecimentos de assuntos, matérias e informações referentes a temas de interesse do CNS; VIII receber da Secretaria-Executiva do CNS matérias, processos, denúncias, pareceres e sugestões, inclusive os provenientes dos Conselhos Estaduais e Municipais de Saúde, para análise e encaminhamentos cabíveis; IX - encaminhar e monitorar as deliberações do Plenário, garantindo o cumprimento dos prazos fixados por este; X - articular-se com os Coordenadores das Comissões e dos Grupos de Trabalho visando atender às deliberações do Plenário, assim como receber os resultados dos trabalhos para ser enviados ao CNS, garantindo os prazos fixados; XI - proceder à seleção de temas para a composição da pauta das Reuniões Ordinárias e das Reuniões Extraordinárias do CNS, priorizando aquelas deliberadas em reunião anterior, observando os seguintes critérios, estabelecidos pelo Pleno, que levam em consideração a:a) pertinência (inserção clara nas atribuições legais do Conselho);b) relevância (inserção nas prioridades temáticas definidas pelo Conselho);c) tempestividade (inserção no tempo oportuno e hábil);d) precedência (ordem da entrada da solicitação);XII - tomar outras providências, visando ao cumprimento de suas atribuições; XIII cumprir e fazer cumprir o Regimento Interno do CNS, submetendo os casos omissos à apreciação do Plenário; e XIV - convocar reuniões com os Coordenadores e Coordenadores Adjuntos das Comissões, aprovadas previamente pelo Plenário."

149 “Art. $9^{\circ}$ A Mesa Diretora do CNS observará, no desenvolvimento do seu trabalho, os seguintes princípios e diretrizes: I - o exercício da democracia, da transparência, da cooperação, da solidariedade, do respeito às diferenças e diferentes na busca da eqüidade; II - a valorização do Conselho Nacional de Saúde para o fortalecimento e a integração do Controle Social nas três instâncias de governo, observando padrões éticos necessários ao desenvolvimento sócio-cultural do País; e III - o respeito e o fortalecimento aos princípios e diretrizes norteadores do SUS."

150 “Art. 53 Os Grupos de Trabalho - GT são organismos instituídos pelo Plenário para assessoramento temporário ao CNS ou às Comissões, com objetivos definidos e prazo para o seu funcionamento fixado em até seis meses. Parágrafo único. Os GT terão como finalidade fornecer subsídios de ordem política, técnica, administrativa, econômico-financeira e jurídica. Art. 54 Os GT serão compostos por até cinco Conselheiros, incluindo o Coordenador, garantindo, preferencialmente, a representação de todos os 
Em novembro de 2011 e março de 2012 ocorreram reuniões de um Grupo de Trabalho criado especificamente com o intuito de avaliar as propostas recebidas através de consulta pública ocorrida entre 12 de setembro a 10 de novembro de 2011 para revisão da Resolução 196/96. A partir da leitura das propostas enviadas através da consulta pública e de outros documentos enviados diretamente à CONEP e a SCTIE, o Grupo de Trabalho entendeu pela necessidade de realização de seminários temáticos, abordando os temas de "Pesquisas públicas no SUS" e "Análise ética de projetos de pesquisa das Ciências Sociais e Humanas e a Resolução CNS 196/96", de forma a aprofundar o debate. Além desses seminários, será também realizado um Encontro Nacional dos Comitês de Ética em Pesquisa (ENCEP) extraordinário de forma a possibilitar a participação dos CEP' s na revisão em tela. Após a realização dos seminários e do ENCEP, o resultado dos debates será trazido ao plenário do CNS para devida votação e aprovação.

Já a Secretaria-Executiva, de acordo com o art. 44 do Regimento Interno, é órgão vinculado ao gabinete do Ministro de Estado e Saúde, com objetivo de prestar suporte técnico-administrativo. Suas competências e atribuições estão previstas, respectivamente, nos artigo 45 e 46 do referido Regimento ${ }^{151}$.

segmentos do CNS. Art. 55 Os Grupos de Trabalho poderão convidar especialistas, representantes das áreas técnicas do Ministério da Saúde e de outros Ministérios, assim como representantes de outras entidades, instituições e movimentos sociais de acordo com suas necessidades e especificidades."

151 "Art. 44 O CNS disporá de uma Secretaria-Executiva que funcionará como suporte técnicoadministrativo às suas atribuições.Parágrafo único. A Secretaria-Executiva é órgão vinculado ao Gabinete do Ministro de Estado da Saúde, tendo por finalidade a promoção do necessário apoio técnico administrativo ao CNS, às suas Comissões e Grupos de Trabalho, fornecendo as condições para o cumprimento das competências expressas neste Regimento. Art. 45 Compete à SecretariaExecutiva: I - assistir ao Conselho Nacional de Saúde na formulação de estratégias e no controle da execução da Política Nacional de Saúde em âmbito federal; II - organizar os processos de: abertura reconhecimento, renovação e aumento de vagas de novos cursos na área da saúde; realização de pesquisas com seres humanos com padrões éticos compatíveis com o desenvolvimento sociocultural do País e demandas oriundas dos Conselhos Estaduais e Municipais de Saúde para deliberação do Pleno; III - promover a divulgação das deliberações do CNS; IV - organizar o processo eleitoral do CNS; V - participar da organização da Conferência Nacional de Saúde e das Conferências Temáticas; VI - promover e praticar os atos de gestão administrativa necessários ao desempenho das atividades do 
Outro organismo que compõe a estrutura do Conselho, a Presidência, é eleita pelo Plenário, na forma do art. $6^{\circ}$ do Decreto $\mathrm{n}^{\circ} 5.839 / 2006$ e art. 69 do Regimento Interno, e possui entre suas atribuições a coordenação da Mesa Diretora e a representação do Conselho em suas relações internas e externas, listadas no art. 13 do Regimento Interno ${ }^{152}$.

As Comissões, por sua vez, e especialmente a Comissão Nacional de Ética em Pesquisa, serão analisadas em tópico apartado, devido a sua relevância para o presente estudo.

CNS e das unidades organizacionais integrantes de sua estrutura; VII - encaminhar ao Ministro de Estado da Saúde a relação dos Conselheiros para designação, conforme o art. $9^{\circ}$ do Decreto no 5.839, de 11 de julho de 2006; e VIII - promover, coordenar e participar do mapeamento e recolhimento de informações e análises estratégicas produzidas nos vários órgãos e entidades dos Poderes Executivo, Legislativo e Judiciário, do Ministério Público e da sociedade, processando-as e fornecendo-as aos Conselheiros na forma de subsídios para o cumprimento das suas competências legais. Art. 46 São atribuições da Secretária-Executiva: I - planejar, coordenar e orientar a execução das atividades do Conselho Nacional de Saúde; II - organizar e providenciar as ações necessárias para a abertura, o reconhecimento, a renovação e o aumento de vagas de novos cursos na área da saúde; III - colocar em ordem as ações relacionadas à pesquisa com a espécie humana; IV - dar encaminhamento às demandas dos Conselhos Estaduais e Municipais de Saúde após a deliberação do Pleno. V - tornar públicas as deliberações do CNS; VI - providenciar todo o material necessário para o processo eleitoral do CNS; VII - participar e promover o apoio técnico-administrativo necessário para a realização das Conferências; VIII - atuar desempenhando atos gestacionais junto ao CNS como um todo; IX encaminhar, para designação por meio de portaria, a relação dos Conselheiros eleitos para o Ministro de Estado da Saúde; X - acompanhar, assessorar e participar da execução e do mapeamento do recolhimento de dados e análises estratégicas formuladas pelos vários órgãos conveniados."

${ }^{152}$ Art. $6^{\circ}$ do Decreto n ${ }^{\circ} 5839 / 2006$ : “Art. 60 O Presidente do CNS será eleito, entre os conselheiros titulares, em escrutínio secreto, na reunião em que tomarem posse os novos membros, votantes somente os membros titulares.".

Artigos 69 e 13 do Regimento Interno: "Art. 69 O Presidente do CNS e os membros da Mesa Diretora serão eleitos pelo Plenário e a Mesa Diretora será composta por Conselheiros titulares"

"Art. 13 São atribuições do Presidente do CNS: I - convocar e coordenar as Reuniões Ordinárias e Extraordinárias do CNS; II - representar o CNS em suas relações internas e externas; III - estabelecer interlocução com órgãos do Ministério da Saúde e demais órgãos do governo e com instituições públicas ou entidades privadas, com vistas ao cumprimento das deliberações do CNS; IV - representar o CNS junto ao Ministério Público, quando as atribuições e deliberações do CNS ou assuntos relativos ao direito à saúde forem desrespeitados ou ocorrer ameaça de grave lesão à saúde pública, desde que aprovado por, no mínimo, a maioria qualificada dos seus membros; V - assinar as Resoluções aprovadas pelo Plenário; VI - decidir, ad referendum, acerca de assuntos emergenciais, quando houver impossibilidade de consulta ao Plenário, submetendo o seu ato à deliberação do Plenário em reunião subseqüente; VII - expedir atos decorrentes de deliberações do CNS; VIII - convocar e coordenar as reuniões da Mesa Diretora; IX - delegar atribuições a outros representantes da Mesa Diretora e demais Conselheiros, sempre que se fizer necessário; X - promover o pleno acesso às informações relevantes para o SUS para fins de deliberação do Plenário; e XI - cumprir e fazer cumprir o Regimento Interno, submetendo os casos omissos à apreciação do Plenário." 


\section{IV - As Comissões}

As comissões do Conselho foram constituídas pela Lei $n^{0} 8.080 / 90$, em seu art. 12, com a finalidade de "articular políticas e programas de interesse para a saúde" ${ }^{153}$. É importante lembrar, contudo, que suas atribuições não incluem a normatização, já que a mesma fica a cargo do Plenário do CNS. Cabe às Comissões, assim como aos Grupos de Trabalho, efetuar um estudo e ampla discussão acerca dos temas subordinados à sua análise, e encaminhar ao pleno suas recomendações, apenas. Desta forma, as Comissões representam uma forma de qualificar as futuras discussões no Pleno, e, a partir deste subsídio, o Plenário é capaz de decidir de forma mais técnica e correta, conforme art. 47 e art. 48 do Regimento Interno ${ }^{154}$. A atuação das Comissões é, sem dúvidas, outra razão de inegável discricionariedade técnica das decisões provindas do CNS.

A Lei 8.080/90 foi mais além e determinou, em seu artigo 13, quais Comissões tem seu funcionamento obrigatório dentro da estrutura do CNS, quais sejam, alimentação e nutrição, saneamento e meio ambiente, vigilância sanitária e farmacoepidemiologia, recursos humanos, ciência e tecnologia e

\footnotetext{
153 “Art. $12^{\circ}$ - Serão criadas comissões intersetoriais de âmbito nacional, subordinadas ao Conselho Nacional de Saúde, integradas pelos ministérios e órgãos competentes e por entidades representativas da sociedade civil. Parágrafo único - As comissões intersetoriais terão a finalidade de articular políticas e programas de interesse para a saúde, cuja execução envolva áreas não compreendidas no âmbito do Sistema Único de Saúde-SUS.”

154 “Art. 47 As Comissões são organismos de assessoria ao Plenário do CNS, que resgatam e reiteram os princípios do SUS e do controle social.

"Art. 48 - As Comissões têm como objetivo articular políticas e programas de interessepara a saúde; as Comissões aprovadas por Resoluções específicas, deixam de fazer parte do Regimento, conforme a Resolução CNS n 435, de 12 e agosto de 2010."§ 1º. As Comissões terão a composição, objetivos, processo de avaliação e plano de trabalho apreciados e aprovados pelo Pleno, e devem analisar as políticas e os programas de suas respectivas áreas, bem como acompanhar as suas implementações, e emitir pareceres e relatórios para subsidiar posicionamento do Pleno"; $§ 2^{\circ}$. As Comissões poderão realizar, quando solicitado pelo Pleno, debates específicos para subsidiar a análise do $\mathrm{CNS} "$. $\S 3^{\circ}$. As Comissões poderão ter suas reuniões e atividades temporariamente suspensas pelo Pleno do CNS após considerar a sua agenda de prioridades, o Planejamento do CNS e a seleção de temas ao longo do ano para a composição da pauta das Reuniões Ordinárias, conforme artigo 12, inciso XI deste regimento.”
} 
saúde do trabalhador ${ }^{155}$. No entanto, a criação de novas Comissões fica a cargo do próprio Conselho, de acordo com disposição do $\S 2^{\circ}$ do art. 52 do Regimento Interno, devendo a Comissão, para tanto, atender aos objetivos do Conselho ${ }^{156}$.

A princípio, as Comissões são formadas por até vinte e duas entidades, movimentos sociais e instituições, de acordo com os objetivos das mesmas, no entanto, o Plenário pode estabelecer de maneira diversa, devido a exigências da situação concreta. Ademais, a Comissão Intersetorial de Recursos Humanos, Comissão Nacional de Ética e Pesquisa e Comissão Intersetorial de Orçamento e Financiamento terão composição específica, em Resolução própria, de acordo com $\S 3^{\circ}$ do art. 49. Além disso, as comissões podem contar com o auxílio de representantes do CONASS e CONASEMS, das áreas técnicas do Ministério da Saúde, outros Ministérios ou quaisquer outros especialistas indicados pelo CNS, ainda, contando com a devida aprovação do Plenário, podem constituir Assessoria Técnica Especializada, nos moldes do art. 49, §2 do Regimento. ${ }^{157}$. Mais uma vez, houve a preocupação do Conselho em

\footnotetext{
155 “Art. $13^{\circ}$ - A articulação das políticas e programas, a cargo das comissões intersetoriais, abrangerá, em especial, as seguintes atividades: I - alimentação e nutrição; II - saneamento e meio ambiente; III Vigilância Sanitária e farmacoepidemiologia; IV - recursos humanos; V - ciência e tecnologia; e VI saúde do trabalhador."

156 “§ $2^{\circ}$ Para a criação de uma Comissão é necessário que esta atenda aos objetivos previstos nos art. 10 e 11 deste Regimento."

157 "Art. 49 - As Comissões serão compostas por até 22 (vinte e duas) entidades, instituições e movimentos nacionais, sendo 12 (doze) titulares, incluídos o Coordenador e Coordenador-Adjunto, ambos conselheiros, sendo pelo menos um deles conselheiro titular e 10 (dez) membros suplentes. $\S 1^{\circ}$ O Plenário poderá, de acordo com as necessidades e especificidades de determinada Comissão, e mediante justificativa fundamentada, aprovar composição diferente da prevista no caput deste artigo, quanto ao número de membros. $\S 2^{\circ}-$ As Comissões poderão convidar representantes das áreas Técnicas do Ministério da Saúde e outros Ministérios, do CONASS e do CONASEMS, especialistas indicados pelo CNS, e a partir da aprovação do Pleno, constituir Assessoria Técnica Especializada de acordo com as necessidades e especificidades da própria comissão." $\$ 3^{\circ}$ - A Comissão Intersetorial de Recursos Humanos, Comissão Nacional de Ética e Pesquisa e Comissão Intersetorial de Orçamento e Financiamento terão numero específico de membros na composição, conforme deliberação do Plenário do CNS. .§ $4^{\circ}$ As indicações das entidades para comporem cada Comissão devem ser de acordo com os seus objetivos e ser submetidas ao Plenário para deliberação."
} 
priorizar a ampliação dos debates, com valorização da intersetorialiedade também nas Comissões, de acordo com o art. 51 do Regimento ${ }^{158}$.

Por fim, e reforçando o disposto no $\S 3^{\circ}$ do art. 49 do Regimento Interno quanto à especificidade da Comissão de Ética em Pesquisa, determinou o $\S 1^{\circ}$ do art. 52, também do Regimento Interno, que esta teria regimento próprio, o que se passa a analisar ${ }^{159}$.

\section{V - CONEP}

A CONEP, Comissão Nacional de Ética em Pesquisa, representa a Comissão do CNS com função de examinar os aspectos éticos das pesquisas envolvendo seres humanos. Dessa forma, possui natureza educativa, consultiva, deliberativa e normativa, de acordo com o item VIII Da Resolução 196/96, anexa, responsável por sua instituição, e do art.1 da Resolução no 446, de 11 de agosto de $2011^{160}$.

No tocante a sua composição, ressalta-se novamente a intenção de pluralizar o debate e torná-lo mais técnico, com uma Comissão formada por trinta membros e cinco suplentes, com mandato de quatro anos, dentre os quais, oito destes membros titulares representarão os segmentos do Conselho Nacional de Saúde de forma paritária, de acordo com art. $2^{\circ}$ da Resolução $n^{\circ}$ $446^{161}$. A partir de lista com indicação dos Comitês de Ética em Pesquisa do

\footnotetext{
158 “Art. 51 Serão considerados membros titulares e suplentes das Comissões, de acordo com as suas especificidades, Conselheiros do CNS, titulares e suplentes, especialistas e representantes de instituições/entidades e movimentos sociais, a fim de garantir a intersetorialidade."

159 "§ $1^{\circ}$ A Comissão Nacional de Ética em Pesquisa - CONEP, pela sua especificidade, possui regimento próprio, que pode ser revisto a qualquer tempo, desde que haja indicação do Plenário."

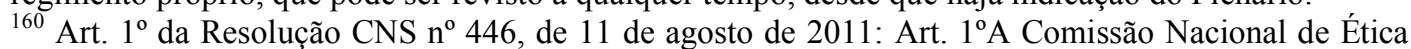
em Pesquisa (CONEP/CNS/MS) é uma instância colegiada, de natureza consultiva, deliberativa, normativa, educativa, independente, vinculada ao Conselho Nacional de Saúde, cujo processo eleitoral dar-se-á de acordo com a presente resolução."

161 “Art. 2o A CONEP/CNS/MS terá composição multi e transdisciplinar, com participação equitativa de homens e mulheres e será composta por 30 (trinta) membros titulares e 5 (cinco) membros
} 
Sistema CEP/CONEP, quinze são escolhidos devido a sua atuação de destaque em sua vida profissional no campo da ética na pesquisa e na saúde, enquanto os demais representam áreas diversas de atuação de forma a conferir à Comissão caráter multidisciplinar ${ }^{162}$. A escolha é realizada pelo Plenário do CNS, através de comissão paritária, que deve assegurar a presença de dois membros que representem a Secretaria de Ciência, Tecnologia e Insumos Estratégicos do Ministério da Saúde, dois representantes do segmento de trabalhadores e quatro conselheiros do segmento de usuários. Ademais, podem ser convidados consultores e outros membros "ad hoc", de forma a incrementar as discussões ${ }^{163}$.

suplentes, que assumirão em eventuais vacâncias ou impossibilidades dos titulares de forma rotativa, sendo que dentre os membros titulares, 8 (oito) representarão os segmentos do Conselho Nacional de Saúde" de forma paritária."

162“"Art. 3o O processo de indicação dos membros da CONEP/CNS/MS será organizado e deliberado pelo Pleno do CNS, a cada biênio, na primeira quinzena do mês de novembro dos anos ímpares. Art. 4o Por deliberação do Pleno do CNS, a Secretaria-Executiva da CONEP/CNS/MS expedirá a todos os Comitês de Ética do Sistema CEP/CONEP ofício de comunicação sobre os prazos para indicações de nomes para comporem a lista de candidatos à CONEP/CNS/MS. § 1o Cada Comitê poderá apresentar até dois nomes para comporem a lista indicativa de candidatos, não necessariamente dentre seus membros. Art. 5o Dentre os componentes da Comissão, 15 (quinze) deverão ser escolhidos por terem se destacado em sua vida profissional no campo da ética na pesquisa e na saúde, devendo os demais representar os diversos campos de atuação capazes de conferir à Comissão caráter multidisciplinar, contemplando os diversos campos do saber: I - os membros titulares e suplentes serão selecionados pelo CNS por análise curricular, a partir da lista indicativa elaborada pela Secretaria-Executiva; II - a lista composta por todos os indicados pelos Comitês de Ética passará por análise prévia de uma comissão composta por 50\% dos membros da CONEP/CNS/MS e 50\% dos membros da Secretaria de Ciência, Tecnologia e Insumos Estratégicos (SCTIE) do Ministério da Saúde, que elaborará Nota Técnica sobre os currículos apresentados, visando subsidiar as eleições no Pleno do CNS, observando especialmente eventuais conflitos de interesses para o exercício de sua função, bem como a qualificação técnica dos indicados, em consonância com as necessidades da CONEP/CNS/MS para o melhor exercício de suas atividades; e III - a Nota Técnica elaborada pela comissão mista CONEP/CNS/MS/SCTIE será encaminhada para o Pleno do CNS, com trinta dias de antecedência da data prevista para a eleição dos membros da CONEP/CNS/MS, juntamente com todos os currículos analisados, as declarações de isenção de conflitos de interesses e as declarações de disponibilidade de tempo para o trabalho voluntário ao qual estão se candidatando."

163 “Art. 6o O CNS indicará comissão eleitoral paritária entre seus segmentos, para conclusão do Processo Eleitoral da CONEP/CNS/MS. Art. 7o Dentre as escolhas do Pleno do CNS para compor a CONEP será assegurada a indicação de 2 (dois) membros representando a Secretaria de Ciência, Tecnologia e Insumos Estratégicos do Ministério da Saúde, 2 (dois) conselheiros(as) do segmento de trabalhadores e 4 (quatro) conselheiros(as) do segmento de usuários. Parágrafo único. A CONEP/CNS/MS poderá contar também com consultores e membros "ad hoc", como convidados a participar de suas reuniões, de acordo com as temáticas em pauta. Art. $80 \mathrm{O}$ mandato dos membros da 
É importante lembrar que sua atuação é conjunta à dos CEP' $\mathrm{s}$, também instituídos pela Resolução 196/96, em seu item VII, que nada mais são que Comitês de Ética em Pesquisa constituídos nas instituições que realizem pesquisas científicas de forma a apreciar toda e qualquer pesquisa científica a ser realizada. A Resolução, da qual retiramos o conceito do CEP de seu item II.14, preocupou-se em estabelecer uma composição multidisciplinar para os CEP' s e uma atuação independente, em seus itens VII a VII.12, alheia a pressões externas, favorecendo decisões democráticas. As atribuições dos CEP' s, que possuem a "responsabilidade primária pelas decisões sobre a ética da pesquisa a ser desenvolvida na instituição", estão listadas no item VII.13 da Resolução 196/96.

Desta forma, os CEP' $s$ encaminham à CONEP questões de áreas temáticas especiais, tais como genética e reprodução humana, populações indígenas, previstas no item VIII.4, alínea “c”, da Resolução 196/96, para que a Comissão as analise. Além disso, cabe à CONEP funcionar como instância recursal e de assessoria ao Ministério da Saúde, Sistema Único de Saúde e, logicamente, do próprio Conselho do qual faz parte. Todas as atribuições da CONEP estão dispostas no item VIII.4 da Resolução 196/96 e no art. 16 da Resolução $n^{\circ} 446$ de 2011. Dentre elas destacamos a responsabilidade de proibir ou interromper pesquisas, de forma temporária ou definitiva e de promover, editar e modificar normas específicas sobre ética em pesquisa, logicamente, com a devida aprovação do Plenário do $\mathrm{CNS}^{164}$. A necessidade

CONEP/CNS/MS será de quatro anos, com renovação alternada a cada dois anos, de quinze de seus membros titulares e dois ou três dos seus membros suplentes. Os membros da CONEP - Conselheiros Nacionais de Saúde - indicados pelo Conselho Nacional de Saúde - CNS terão seu mandato de acordo com o art.7o do Decreto no 5.839, de 11 de julho de 2011."

${ }^{164}$ Art. 16 da Resolução no 446: "Art. 16. Compete à CONEP/CNS/MS o exame dos aspectos éticos da pesquisa envolvendo seres humanos, bem como a adequação e atualização das normas atinentes, podendo, para tanto, consultar a sociedade sempre que julgar necessário, cabendo-lhe ainda, dentre outras, as seguintes atribuições: I - estimular a participação popular nas iniciativas de Controle Social das Pesquisas com Seres Humanos, bem como criação de CEP institucionais e de outras instâncias, sempre que tal criação possa significar o fortalecimento da proteção de sujeitos de pesquisa no Brasil; II - registrar, supervisionar e cancelar, nos casos devidos, conforme resolução específica deliberada pelo 


\section{de deliberação pelo CNS se estende também ao plano de trabalho anual e ao relatório anual de atividades, na forma do item VIII.5 da Resolução 196/96 e} art. 17 da Resolução no $446^{165}$.

CNS, os CEP que compõem a rede CEP/CONEP/CNS/MS; III - formular diretrizes para o processo de acreditação dos comitês de ética em pesquisa registrados no Sistema CEP/CONEP/CNS/MS, que será objeto de resolução especifica do CNS; e IV - analisar e emitir parecer, no prazo de 60 dias, e acompanhar os protocolos de pesquisa em áreas temáticas especiais tais como: 1. genética humana sempre que o projeto envolver: 1.1. envio para o exterior de material genético ou qualquer material biológico humano para obtenção de material genético; 1.2. armazenamento de material biológico ou dados genéticos humanos no exterior e no País, quando de forma conveniada com instituições estrangeiras ou em instituições comerciais; 1.3. alterações da estrutura genética de células humanas para utilização in vivo; 1.4. pesquisas na área da genética da reprodução humana (reprogenética); 1.5. pesquisas em genética do comportamento; e 1.6. pesquisas em que esteja prevista a dissociação irreversível dos dados dos sujeitos de pesquisa; 2. reprodução humana: pesquisas que se ocupam com o funcionamento do aparelho reprodutor, procriação e fatores que afetam a saúde reprodutiva de humanos, sendo que nessas pesquisas serão considerados "sujeitos da pesquisa" todos os que forem afetados pelos procedimentos delas. Caberá análise da CONEP/CNS/MS sempre que o projeto envolver: 2.1. reprodução assistida; 2.2. manipulação de gametas, pré-embriões, embriões e feto; e 2.3. medicina fetal; 3. vacinas novas (fases I, II e III) ou não registradas no País (ainda que fase IV), ou quando a pesquisa for referente a seu uso com modalidades, indicações, doses ou vias de administração diferentes daquelas estabelecidas, incluindo seu emprego em combinações; 4. equipamentos, insumos e dispositivos para a saúde, novos ou não registrados no País; 5. novos procedimentos ainda não consagrados na literatura; 6. estudos com populações indígenas; 7. projetos que envolvam aspectos de biossegurança: projetos de pesquisa que envolvam organismos geneticamente modificados (OGM), células tronco embrionárias e organismos que representam alto risco coletivo, incluindo organismos relacionados a eles, conforme discriminação adiante, nos âmbitos de: experimentação, construção, cultivo, manipulação, transporte, transferência, importação, exportação, armazenamento, liberação no meio ambiente e descarte; 8. pesquisas coordenadas no exterior ou com participação estrangeira e pesquisas que envolvam remessa de material biológico humano para o exterior. Não cabe análise da CONEP/CNS/MS nos seguintes casos: 8.1. aquelas cuja participação brasileira se restrinja à formação acadêmica de pesquisador estrangeiro vinculado a programa de pós-graduação nacional e não envolva participação de sujeitos de pesquisa brasileiros em nenhuma de suas etapas; e 8.2. aquelas cujas etapas sejam totalmente realizadas no exterior e que tenham sido aprovadas por comitê de ética em pesquisa ou órgão equivalente no País de origem; 9. projetos que, a critério do CEP, sejam julgados merecedores de análise pela CONEP/CNS/MS; 10. protocolos de constituição e funcionamento de biobancos; V promover normas específicas no campo da ética em pesquisa, inclusive nas áreas temáticas especiais, bem como recomendações para a sua aplicação, sempre com a indispensável deliberação do Pleno do CNS; VI - funcionar como instância final de recursos, a partir de informações fornecidas sistematicamente, em caráter ex-offício, ou a partir de denúncias, ou de solicitação de partes interessadas, devendo manifestar-se em um prazo não superior a 60 (sessenta) dias; VII - apurar responsabilidades, proibir ou interromper pesquisas definitivas ou temporárias, podendo requisitar protocolos para revisão ética, inclusive, os já aprovados pelo CEP; VIII - acompanhar a gestão da Plataforma Brasil; IX - informar e assessorar o MS, o CNS e outras instâncias do SUS, bem como do governo e da sociedade, sobre questões éticas relativas à pesquisa em seres humanos; X - divulgar esta e outras normas relativas à ética em pesquisa envolvendo seres humanos; e XI - estabelecer suas próprias normas de funcionamento, sempre submetendo ao Pleno do CNS para aprovação."

165 “Art. 17. A CONEP/CNS/MS submeterá ao CNS para sua deliberação: I - propostas de normas gerais a serem aplicadas às pesquisas envolvendo seres humanos, inclusive modificações desta norma; II - plano de trabalho anual; e III - relatório anual de suas atividades, incluindo sumário dos CEP credenciados e acreditados, bem como dos projetos analisados." 
Tais reuniões são, em princípio, fechadas ao público, uma vez que o sigilo se faz necessário, nos moldes do $\S 1^{\circ}$ do art. 13 da Resolução n $446^{166}$. Ademais, visando maior qualidade nas decisões, poderão ser realizados seminários e mesas temáticas, abertas ao público, e serem convidados pesquisadores, patrocinadores de pesquisas, membros da imprensa, dentre outros, para prestar os esclarecimentos de forma a facilitar as discussões e possíveis decisões, de acordo com os $\S \S 2^{\circ}$ e $3^{\circ}$ do art. 13 da Resolução $n^{\circ} 446$. 167

Percebe-se, desta forma, que a atuação da CONEP é deveras técnica, em sua específica área, devido à participação de personalidades de destaque em áreas diversas. A participação de consultores e possibilidade de realização de seminários e mesmas temáticas são outras formas de se chegar à decisão mais certada, enquanto a participação de usuários confirma, novamente, o atendimento à democracia participativa. Torna-se mais uma vez inconteste que

\footnotetext{
166 “Art. 13. A CONEP/CNS/MS se reunirá ordinariamente uma vez ao mês, de janeiro a dezembro, e extraordinariamente, sempre que necessário, podendo instituir câmaras temáticas de análise ética, tanto com seus membros como com convidados "ad hoc", para melhor qualificar e agilizar o processo. $\$ 10$ $\mathrm{O}$ conteúdo tratado durante as reuniões da CONEP/CNS/MS é de ordem sigilosa, sendo que suas reuniões são, em princípio, fechadas ao público, à imprensa ou a qualquer visitante, e todos os seus membros, bem como os membros de sua Secretaria-Executiva, deverão comprometer-se, expressamente por escrito, a manter sigilo dos temas, pareceres e decisões tratados em Plenária, constituindo-se falta a quebra de tal compromisso, que poderá originar afastamento do membro."
}

167 “Art.13. A CONEP/CNS/MS se reunirá ordinariamente uma vez ao mês, de janeiro a dezembro, e extraordinariamente, sempre que necessário, podendo instituir câmaras temáticas de análise ética, tanto com seus membros como com convidados "ad hoc", para melhor qualificar e agilizar o processo. (...) $\S$ 2o A CONEP/CNS/MS poderá realizar seminários e mesas temáticas abertas ao público, sempre que julgar pertinente, para esclarecer, aprofundar ou debater temas de interesse do Sistema CEP/CONEP, sendo que, nessas ocasiões, será divulgado, com a devida antecedência, no site eletrônico da Comissão, bem como em outros meios virtuais, a disponibilidade para as inscrições nesses eventos. § $30 \mathrm{~A}$ CONEP/CNS/MS poderá convidar, especificamente, pesquisadores, patrocinadores de pesquisas, membros da imprensa, dentre outros, para prestar os esclarecimentos que julgar necessários para o melhor desempenho das suas atividades ou para o melhor interesse dos sujeitos de pesquisa brasileiros, sendo que as audiências ou participações em Plenária serão sempre registradas em ata e ocorrerão sempre com a presença de, pelo menos, três membros da Comissão.” 
o processo decisório abordado corresponde ao diálogo necessário entre a sociedade civil e o conhecimento técnico capaz de possibilitar a qualidade nas decisões e, ao mesmo tempo, a participação da sociedade.

\section{VI - Atribuição do CNS}

De início, é fundamental que seja lembrado que toda a atuação do Conselho Nacional de Saúde visa à proteção dos indivíduos e grupos. Desta feita, seus maiores alicerces de atuação são um dos fundamentos da República Federativa do Brasil, prevista em seu art. $1^{\circ}$, inciso III, a saber, a dignidade da pessoa humana, o direito a saúde e o direito à vida ${ }^{168}$. Somente com um controle e acompanhamento efetivo acerca das políticas de saúde e com o desenvolvimento de normas com a devida precisão técnica, será possível afirmar que de fato o sistema de saúde pátrio respeita a fundo os direitos retromencionados.

Ademais, em seu art. 196, a Carta Magna estabelece ser a saúde, além de um direito social como já mencionado, também um dever do Estado, devendo este garanti-la através de políticas sociais e econômicas ${ }^{169}$. Igualmente, define, no art. 197, ser atribuição do Estado dispor sobre a regulamentação, controle e fiscalização das ações e serviços de saúde ${ }^{170}$. Além disso, os anseios populares por maior participação política foram atendidos pelo legislador ordinário

\footnotetext{
168“'Art. 1 ${ }^{\circ}$ A República Federativa do Brasil, formada pela união indissolúvel dos Estados e Municípios e do Distrito Federal, constitui-se em Estado Democrático de Direito e tem como fundamentos: I - a soberania; II - a cidadania III - a dignidade da pessoa humana; IV - os valores sociais do trabalho e da livre iniciativa; V - o pluralismo político. Parágrafo único. Todo o poder emana do povo, que o exerce por meio de representantes eleitos ou diretamente, nos termos desta Constituição."
}

\footnotetext{
169،“Art. 196. A saúde é direito de todos e dever do Estado, garantido mediante políticas sociais e econômicas que visem à redução do risco de doença e de outros agravos e ao acesso universal e igualitário às ações e serviços para sua promoção, proteção e recuperação.”

170“Art. 197. São de relevância pública as ações e serviços de saúde, cabendo ao Poder Público dispor, nos termos da lei, sobre sua regulamentação, fiscalização e controle, devendo sua execução ser feita diretamente ou através de terceiros e, também, por pessoa física ou jurídica de direito privado."
} 
quando este determinou, no art.198, inciso III, que a participação da comunidade representa uma das diretrizes a serem observadas pelas referidas ações e serviços públicos de saúde ${ }^{171}$.

Mais, dispôs o art. 200, da Carta Magna, acerca das atribuições do SUS, dentre as quais salientamos o dever de controlar a fiscalizar procedimentos de interesse para a saúde e de promover o desenvolvimento científico, que serão exercidas em grande parte pela instância colegiada em estudo, o Conselho Nacional de Saúde ${ }^{172}$.

Nesse sentido, afirma-se que a atribuição do Conselho Nacional de Saúde, instância colegiada do Sistema Único de Saúde (SUS), deriva, inicialmente, de mandamento constitucional.

Em 19 de setembro de 1990 foi então editada a Lei 8.080, já referida, sendo a mesma responsável por regular as ações e políticas de saúde no território brasileiro ${ }^{173}$. Dispôs também, sobre a constituição do SUS, seus

\footnotetext{
171 “Art. 198. As ações e serviços públicos de saúde integram uma rede regionalizada e hierarquizada e constituem um sistema único, organizado de acordo com as seguintes diretrizes: I - descentralização, com direção única em cada esfera de governo; II - atendimento integral, com prioridade para as atividades preventivas, sem prejuízo dos serviços assistenciais; III - participação da comunidade."
}

172 “Art. 200. Ao sistema único de saúde compete, além de outras atribuições, nos termos da lei: I controlar e fiscalizar procedimentos, produtos e substâncias de interesse para a saúde e participar da produção de medicamentos, equipamentos, imunobiológicos, hemoderivados e outros insumos; II executar as ações de vigilância sanitária e epidemiológica, bem como as de saúde do trabalhador; III ordenar a formação de recursos humanos na área de saúde; IV - participar da formulação da política e da execução das ações de saneamento básico; V - incrementar em sua área de atuação o desenvolvimento científico e tecnológico; VI - fiscalizar e inspecionar alimentos, compreendido o controle de seu teor nutricional, bem como bebidas e águas para consumo humano; VII - participar do controle e fiscalização da produção, transporte, guarda e utilização de substâncias e produtos psicoativos, tóxicos e radioativos; VIII - colaborar na proteção do meio ambiente, nele compreendido o do trabalho."

173 “Art. $1^{\text {o }}$ Esta lei regula, em todo o território nacional, as ações e serviços de saúde, executados isolada ou conjuntamente, em caráter permanente ou eventual, por pessoas naturais ou jurídicas de direito Público ou privado." 
objetivos e seu campo de atuação, respectivamente nos arts. $4^{\mathrm{o}}, 5^{\mathrm{o}}$ e $6^{\mathrm{o}} .^{174}$ No art. 15, estabeleceu as atribuições da União, estados, Distrito Federal e

174 “Art. $4^{\circ} \mathrm{O}$ conjunto de ações e serviços de saúde, prestados por órgãos e instituições públicas federais, estaduais e municipais, da Administração direta e indireta e das fundações mantidas pelo Poder Público, constitui o Sistema Único de Saúde (SUS). § $1^{\circ}$ Estão incluídas no disposto neste artigo as instituições públicas federais, estaduais e municipais de controle de qualidade, pesquisa e produção de insumos, medicamentos, inclusive de sangue e hemoderivados, e de equipamentos para saúde. $\S 2^{\circ}$ A iniciativa privada poderá participar do Sistema Único de Saúde (SUS), em caráter complementar.

Art. $5^{\circ}$ São objetivos do Sistema Único de Saúde SUS: I - a identificação e divulgação dos fatores condicionantes e determinantes da saúde; II - a formulação de política de saúde destinada a promover, nos campos econômico e social, a observância do disposto no $\S 1^{\circ}$ do art. $2^{\circ}$ desta lei; III - a assistência às pessoas por intermédio de ações de promoção, proteção e recuperação da saúde, com a realização integrada das ações assistenciais e das atividades preventivas. Art. $6^{\circ}$ Estão incluídas ainda no campo de atuação do Sistema Único de Saúde (SUS):I - a execução de ações: a) de vigilância sanitária; b) de vigilância epidemiológica; c) de saúde do trabalhador; e d) de assistência terapêutica integral, inclusive farmacêutica; II - a participação na formulação da política e na execução de ações de saneamento básico; III - a ordenação da formação de recursos humanos na área de saúde; IV - a vigilância nutricional e a orientação alimentar; V - a colaboração na proteção do meio ambiente, nele compreendido o do trabalho; VI - a formulação da política de medicamentos, equipamentos, imunobiológicos e outros insumos de interesse para a saúde e a participação na sua produção; VII - o controle e a fiscalização de serviços, produtos e substâncias de interesse para a saúde; VIII - a fiscalização e a inspeção de alimentos, água e bebidas para consumo humano; IX - a participação no controle e na fiscalização da produção, transporte, guarda e utilização de substâncias e produtos psicoativos, tóxicos e radioativos; X - o incremento, em sua área de atuação, do desenvolvimento científico e tecnológico; XI - a formulação e execução da política de sangue e seus derivados.§ $1^{\circ}$ Entende-se por vigilância sanitária um conjunto de ações capaz de eliminar, diminuir ou prevenir riscos à saúde e de intervir nos problemas sanitários decorrentes do meio ambiente, da produção e circulação de bens e da prestação de serviços de interesse da saúde, abrangendo: I - o controle de bens de consumo que, direta ou indiretamente, se relacionem com a saúde, compreendidas todas as etapas e processos, da produção ao consumo; e II - o controle da prestação de serviços que se relacionam direta ou indiretamente com a saúde. $\S 2^{\circ}$ Entende-se por vigilância epidemiológica um conjunto de ações que proporcionam o conhecimento, a detecção ou prevenção de qualquer mudança nos fatores determinantes e condicionantes de saúde individual ou coletiva, com a finalidade de recomendar e adotar as medidas de prevenção e controle das doenças ou agravos. $\S 3^{\circ}$ Entende-se por saúde do trabalhador, para fins desta lei, um conjunto de atividades que se destina, através das ações de vigilância epidemiológica e vigilância sanitária, à promoção e proteção da saúde dos trabalhadores, assim como visa à recuperação e reabilitação da saúde dos trabalhadores submetidos aos riscos e agravos advindos das condições de trabalho, abrangendo: I - assistência ao trabalhador vítima de acidentes de trabalho ou portador de doença profissional e do trabalho; II - participação, no âmbito de competência do Sistema Único de Saúde (SUS), em estudos, pesquisas, avaliação e controle dos riscos e agravos potenciais à saúde existentes no processo de trabalho; III - participação, no âmbito de competência do Sistema Único de Saúde (SUS), da normatização, fiscalização e controle das condições de produção, extração, armazenamento, transporte, distribuição e manuseio de substâncias, de produtos, de máquinas e de equipamentos que apresentam riscos à saúde do trabalhador; IV avaliação do impacto que as tecnologias provocam à saúde; V - informação ao trabalhador e à sua respectiva entidade sindical e às empresas sobre os riscos de acidentes de trabalho, doença profissional e do trabalho, bem como os resultados de fiscalizações, avaliações ambientais e exames de saúde, de admissão, periódicos e de demissão, respeitados os preceitos da ética profissional; VI - participação na normatização, fiscalização e controle dos serviços de saúde do trabalhador nas instituições e empresas públicas e privadas; VII - revisão periódica da listagem oficial de doenças originadas no processo de 
Municípios em âmbito administrativo, entre as quais pode-se destacar a de elaborar normas técnico-científicas de promoção e proteção da saúde e de "promover articulação com os órgãos de fiscalização do exercício profissional, e outras entidades representativas da sociedade civil, para a definição e controle dos padrões éticos para a pesquisa, ações e serviços de saúde" ${ }^{\text {175 }}$.

Em 28 de dezembro de 1990, com a superveniência da Lei 8.142, ficou definida que a atuação do CNS seria na "formulação de estratégias e no controle da execução da política de saúde na instância correspondente, inclusive nos aspectos

trabalho, tendo na sua elaboração a colaboração das entidades sindicais; e VIII - a garantia ao sindicato dos trabalhadores de requerer ao órgão competente a interdição de máquina, de setor de serviço ou de todo ambiente de trabalho, quando houver exposição a risco iminente para a vida ou saúde dos trabalhadores."

175 “Art. $15^{\circ}$ A União, os estados, o Distrito Federal e os municípios exercerão, em seu âmbito administrativo, as seguintes atribuições: I - definição das instâncias e mecanismos de controle, avaliação e fiscalização das ações e serviços de saúde; II - administração dos recursos orçamentários e financeiros destinados, em cada ano, à saúde; III - acompanhamento, avaliação e divulgação do nível de saúde da população e das condições ambientais; IV - organização e coordenação do sistema de informação em saúde; V - elaboração de normas técnicas e estabelecimento de padrões de qualidade e parâmetros de custos que caracterizam a assistência à saúde; VI - elaboração de normas técnicas e estabelecimento de padrões de qualidade para promoção da saúde do trabalhador; VII - participação de formulação da política e da execução das ações de saneamento básico e colaboração na proteção e recuperação do meio ambiente; VIII - elaboração e atualização periódica do plano de saúde; IX participação na formulação e na execução da política de formação e desenvolvimento de recursos humanos para a saúde; X - elaboração da proposta orçamentária do Sistema Único de Saúde-SUS, de conformidade com o plano de saúde; XI - elaboração de normas para regular as atividades de serviços privados de saúde, tendo em vista a sua relevância pública; XII - realização de operações externas de natureza financeira de interesse da saúde, autorizadas pelo Senado Federal; XIII - para atendimento de necessidades coletivas, urgentes e transitórias, decorrentes de situações de perigo iminente, de calamidade pública ou de irrupção de epidemias, a autoridade competente da esfera administrativa correspondente poderá requisitar bens e serviços, tanto de pessoas naturais como jurídicas, sendo-lhes assegurada justa indenização; XIV - implementar o Sistema Nacional de Sangue, Componentes e Derivados; XV - propor a celebração de convênios, acordos e protocolos internacionais relativos a saúde, saneamento e o meio ambiente; XVI - elaborar normas técnico-científicas de promoção, proteção e recuperação da saúde; XVII - promover articulação com os órgãos de fiscalização do exercício profissional, e outras entidades representativas da sociedade civil, para a definição e controle dos padrões éticos para a pesquisa, ações e serviços de saúde; XVIII - promover a articulação da política e dos planos de saúde; XIX - realizar pesquisas e estudos na área de saúde; XX - definir as instâncias e mecanismos de controle e fiscalização inerentes ao poder da política sanitária; XXI fomentar, coordenar e executar programas e projetos estratégicos e de atendimento emergencial." 
econômicos e financeiros, cujas decisões serão homologadas pelo chefe do poder legalmente constituído em cada esfera do governo", nos moldes do $\$ 2^{\circ}$ de seu art. $1^{\text {o }}{ }^{176}$.

A disposição no ordenamento jurídico atual acerca das atribuições do CNS estão presentes ainda no art. $2^{\circ}$ do Decreto 5.839/2006, dentre as quais salientamos a atribuição de acompanhar o desenvolvimento científico, de forma que padrões éticos sejam respeitados ${ }^{177}$.

Por fim, a atribuição do Conselho também encontra previsão em seu Regimento Interno, dispondo este acerca de suas competências em seu art. $10^{\circ}$, com redação praticamente idêntica ao art. $2^{\circ}$ do Decreto 5.839/2006. A diferença entre ambos os artigos dá-se apenas pela inclusão do inciso IX na previsão do Regimento Interno, referente ao fortalecimento da participação e controle social no SUS ${ }^{178}$.

\footnotetext{
176 “ $§ 2^{\circ}$ O Conselho de Saúde, em caráter permanente e deliberativo, órgão colegiado composto por representantes do governo, prestadores de serviço, profissionais de saúde e usuários, atua na formulação de estratégias e no controle da execução da política de saúde na instância correspondente, inclusive nos aspectos econômicos e financeiros, cujas decisões serão homologadas pelo chefe do poder legalmente constituído em cada esfera do governo."

177 "Art. $2^{\circ}$ Ao CNS compete: I - atuar na formulação de estratégias e no controle da execução da Política Nacional de Saúde, na esfera do Governo Federal, inclusive nos aspectos econômicos e financeiros; II - estabelecer diretrizes a serem observadas na elaboração dos planos de saúde, em função das características epidemiológicas e da organização dos serviços; III - elaborar cronograma de transferência de recursos financeiros aos Estados, ao Distrito Federal e aos Municípios, consignados ao Sistema Único de Saúde - SUS; IV - aprovar os critérios e os valores para remuneração de serviços e os parâmetros de cobertura de assistência; V - propor critérios para a definição de padrões e parâmetros assistenciais; VI - acompanhar e controlar a atuação do setor privado da área da saúde, credenciado mediante contrato ou convênio; VII - acompanhar o processo de desenvolvimento e incorporação científica e tecnológica na área de saúde, visando à observação de padrões éticos compatíveis com o desenvolvimento sócio-cultural do País; e VIII - articular-se com o Ministério da Educação quanto à criação de novos cursos de ensino superior na área de saúde, no que concerne à caracterização das necessidades sociais."
}

178 “Art. 10 Compete ao Conselho Nacional de Saúde: I - atuar na formulação de estratégias e no controle da execução da Política Nacional de Saúde, na esfera do Governo Federal, inclusive nos aspectos econômicos e financeiros; II - estabelecer diretrizes a ser observadas na elaboração dos planos de saúde, em razão das características epidemiológicas e da organização dos serviços; III - elaborar cronograma de transferência de recursos financeiros aos Estados, ao Distrito Federal e aos Municípios, consignados ao SUS; IV - aprovar os critérios e os valores para remuneração de serviços e os parâmetros de cobertura de assistência; V - propor critérios para a definição de padrões e parâmetros assistenciais; VI - acompanhar e controlar a atuação do setor privado da área da saúde, credenciado mediante contrato ou convênio; VII - acompanhar o processo de desenvolvimento e incorporação científica e tecnológica na área de saúde, visando à observação de padrões éticos compatíveis com o desenvolvimento sócio-cultural do País; VIII - articular-se com o Ministério da Educação quanto à 


\section{VII - Dinâmica decisória}

A razão deste tópico consiste na exposição das similitudes entre o processo decisório do Conselho Nacional de Saúde e do Congresso Nacional. Ademais, o objetivo é observar, até que ponto, dá-se a controlabilidade dos atos do Conselho pelo Ministro da Saúde.

O processo decisório do Conselho se dá através de votações no plenário que são iniciadas por discussões, na chamada Ordem do Dia. De acordo com o art. 21 do Regimento Interno do CNS, devem constar, preferencialmente, na ordem do dia, matérias já previamente analisadas por comissão própria ou por conselheiro designado e ainda, cada Conselheiro inscrito terá um tempo, previamente acordado, para sua intervenção ${ }^{179}$. Após a apresentação do tema, qualquer Conselheiro tem direito de pedir vista, ocorrendo, nesta hipótese, suspensão da discussão, que deverá ocorrer na Reunião Ordinária subsequente, conforme art. 24 do referido Regimento ${ }^{180}$. Ainda, as matérias em discussão

criação de novos cursos de ensino superior na área da saúde, no que concerne à caracterização das necessidades sociais; e IX - fortalecer a participação e o controle social no SUS"

179، Art. $21 \mathrm{~A}$ ordem do dia é a fase da reunião destinada à apresentação, debate e deliberação de temas, conforme o caso, devendo constar de cada tema pautado a respectiva indicação da condição do caso. $\S$ $1^{\circ}$ Deverão constar da ordem do dia, preferencialmente, matérias que já tenham sido apreciadas pela comissão permanente pertinente ao assunto, ou por conselheiro-relator designado pelo Plenário ou pela Mesa Diretora. $\S 2^{\circ}$ Para cada tema será destinado um tempo preestabelecido cuja duração definirá o número de Conselheiros inscritos para intervenção. $\S 3^{\circ}$ Cada Conselheiro inscrito disporá de tempo previamente acordado para sua intervenção, sendo que a reinscrição só será concedida se o tempo destinado ao tema assim o permitir, havendo precedência de novas inscrições sobre as reinscrições. $\S$ $4^{\circ}$ Caso a discussão de um tema não seja concluída no tempo preestabelecido, o tema será automaticamente remetido para a próxima reunião, exceto se o Plenário entender que o assunto tratado é de extrema relevância e/ou urgência que não permita o seu adiamento, devendo, nesse caso, ser retirado de pauta e remetido para outro momento durante a reunião, destinando tempo necessário para a conclusão da discussão."

180

"Art. 24 Apresentado o tema, qualquer Conselheiro poderá pedir vista para melhor avaliação do ponto de pauta, cabendo ao Conselheiro ser relator do processo, remetendo-se a discussão sobre o tema para a Reunião Ordinária subsequente, conforme calendário aprovado no $\S 1^{\circ}$ do art. 15 deste Regimento.§ $1^{\circ}$ Ocorrendo o pedido de vista da matéria, a discussão ficará suspensa automaticamente. $\S 2^{\circ}$ A matéria retirada da ordem do dia, em virtude de pedido de vista, será devolvida à SecretariaExecutiva até dez dias antes da reunião subsequente, para ser disponibilizada ao CNS, acompanhada 
estão sujeitas a pedidos de encaminhamento, esclarecimento e defesa, nos moldes do art. 25 do Regimento ${ }^{181}$.

A questão de ordem representa qualquer dúvida em relação à observância, interpretação ou aplicação de mandamento legal ou do próprio Regimento, de acordo com o caput do art. 26 do Regimento Interno ${ }^{182}$. A questão do encaminhamento, por sua vez, consiste em manifestação do Conselheiro visando ao melhor andamento do processo, no qual se questiona a condução atual daquele tema ${ }^{183}$. Já a questão de esclarecimento representa a manifestação dos Conselheiros acerca de dúvidas sobre o tema, que devem ser elucidadas antes do início da votação ${ }^{184}$. Os Conselheiros podem valer-se, ainda, do aparte, que representa a interrupção da intervenção de um Conselheiro também para esclarecimento da matéria. O aparte, contudo, encontra limites, como, por exemplo, no impedimento de sua utilização quando já iniciada a votação ou quando tratar-se de questão de ordem, de acordo com o $\S 3^{\circ}$ do art. 31 do Regimento ${ }^{185}$.

do parecer emitido pelo Conselheiro que pediu vista. $\S 3^{\circ}$ Havendo pedido de vista, o Presidente consultará o Plenário quanto ao interesse de mais algum Conselheiro utilizar-se do mesmo direito, uma vez que não haverá novo pedido de vista. $\S 4^{\circ}$ Quando mais de um Conselheiro pedir vista de uma matéria, o prazo para apresentação dos pareceres será o mesmo previsto no $\S 1^{\circ}$ deste artigo, devendo a Secretaria- Executiva fornecer o material disponível para a elaboração dos seus pareceres. $\S 5^{\circ} \mathrm{O}$ Conselheiro perde o direito de apresentação e apreciação do seu parecer, nas seguintes situações: I não cumprimento do prazo estabelecido no $\S 1^{\circ}$ deste artigo; e II - não comparecimento na reunião designada para tal fim. $\S 6^{\circ}$ É vedado ao Conselheiro relator designar a outro a apresentação do seu parecer."

181 “Art. 25. Matérias sujeitas à deliberação podem ser objeto de esclarecimentos, encaminhamentos e defesa. Parágrafo único. As matérias não sujeitas à deliberação admitem apenas questões de encaminhamento e esclarecimento, cabendo ao Coordenador da Sessão Plenária alertar os Conselheiros quando estiverem utilizando indevidamente as formas de intervenções previstas."

182 "Art. 26 Considera-se questão de ordem toda dúvida sobre a interpretação, aplicação ou inobservância do Regimento Interno do CNS ou outro dispositivo legal."

183 "Art. 27 A questão de encaminhamento é a manifestação do Conselheiro quanto ao processo de condução do tema tratado no momento, com vista ao melhor andamento da Reunião."

184 “Art. 30 É o instrumento que o Conselheiro poderá utilizar para esclarecimento de dúvidas, dirigida ao Coordenador da Sessão Plenária, antes do processo de votação, sendo concedido tempo máximo de três minutos para manifestação."

185 "Art. 31 Considera-se aparte a interrupção da intervenção de um Conselheiro para indagação ou esclarecimento relativo à matéria em discussão, não podendo o Conselheiro ultrapassar um minuto. $\S$ $1^{\circ} \mathrm{O}$ Conselheiro só poderá apartear se houver permissão do orador. $\S 2^{\circ} \mathrm{O}$ aparte está incluído no tempo estabelecido ao Conselheiro. $\S 3^{\circ}$ Não será permitido aparte nas seguintes situações: I - por 
Assim, parte-se para o processo de votação. Tal processo pode ser iniciado através da defesa de proposta, na qual são ouvidas defesas contrárias e favoráveis à mesma, até que o Plenário encontre-se totalmente esclarecido, nos moldes do art. 32 do Regimento Interno ${ }^{186}$.

O processo de votação poderá ser nominal ou simbólico, através do levantamento de braço, de forma análoga as decisões do Congresso Nacional. Assim, o processo comum de decisão será mediante sistema simbólico, ressalvados os casos em que haja requerimento de Conselheiro, nos moldes do art. 34 do Regimento ${ }^{187}$. De acordo com o art. 35 do mesmo Regimento, na votação simbólica o resultado é proclamado pelo contraste ou pela contagem de votos. Ainda, caso haja dúvida e seja requerido, poderá ser realizada a recontagem de votos através do sistema simbólico ou pelo processo nominal ${ }^{188}$.

ocasião da apresentação do expediente; II - em regime de votação; III - quando o orador declarar, previamente, que não o concederá; IV - quando se tratar de questão de ordem; V - quando o tempo restante da intervenção for inferior a um minuto; e VI - quando já tiver concedido um aparte na mesma intervenção."

186 “Art. 32 Encerrada a discussão, será iniciado imediatamente o processo de votação. $\S 1^{\circ} \mathrm{O}$ Coordenador da Sessão Plenária consultará o Plenário sobre a necessidade de defesa da proposta em regime de votação. $\S 2^{\circ}$ Sendo considerada pelo Plenário a necessidade de defesa de proposta, o Coordenador da Sessão Plenária concederá a palavra para defesas favoráveis e contrárias até que o Plenário tenha sido totalmente esclarecido para a votação. $\S 3^{\circ} \mathrm{O}$ prazo de intervenção da defesa de proposta sempre será de três minutos improrrogáveis."

187 “Art. 34 O processo de votação poderá ser nominal ou simbólico por meio do levantamento do braço. $\S 1^{\circ}$ As matérias não destacadas da ordem do dia serão votadas, globalmente, pelo processo simbólico, antes da apreciação dos destaques solicitados e das propostas apresentadas. $\S 2^{\circ} \mathrm{O}$ processo comum de votação será o simbólico, salvo quando algum Conselheiro requerer votação nominal."

${ }^{188}$ Art. 35 Na votação simbólica, o Coordenador da Sessão Plenária solicitará aos Conselheiros que se manifestem favoráveis, contrários ou abstenham-se, levantando o braço, e o resultado será proclamado por contraste ou pela contagem de votos. $\S 1^{\circ}$ Havendo dúvida quanto ao resultado proclamado, e se for requerida a verificação da votação, a recontagem de votos será realizada imediatamente pelo processo simbólico ou quando solicitada pelo processo nominal. $\S 2^{\circ} \mathrm{O}$ Conselheiro que se abstiver e manifestar o desejo de fazer declaração de voto poderá, após a votação, fazê-lo pelo prazo máximo de um minuto, ou entregá-la por escrito, durante a sessão, à Secretaria-Executiva para registro em ata e arquivamento da íntegra do pronunciamento para eventual consulta futura." 
Já no processo nominal, a contagem ocorre ao final da resposta positiva, negativa ou de abstenção dos Conselheiros ${ }^{189}$.

Prosseguindo, cada Conselheiro tem direito a um voto e a matéria é considerada aprovada caso seja obtida a maioria dos votos, salvo na hipótese do somatório dos votos favoráveis e contrários não seja superior ao de abstenções ou em casos em que se exija quórum especial, de acordo com o caput do art. 39 e art. 37 do Regimento ${ }^{190}$. O direito de voto dos Conselheiros é também previsto no $\S 3^{\circ}$ do art. 15 do Regimento Interno, responsável por estabelecer ainda que o quórum de instalação das reuniões do CNS é de maioria absoluta ${ }^{191}$. Caso o quórum de instalação não seja atingido, a sessão é suspensa, até que haja sua recomposição. Caso não ocorra a recomposição até duas horas após a suspensão da sessão, a matéria é remetida para a reunião subsequente, caso seja exigido quórum especial para sua votação, dando-se prosseguimento à análise das demais matérias, ou será declarada encerrada a sessão, e a matéria, da qual exige-se quórum simples, será também apreciada na sessão subsequente ${ }^{192}$.

189 Art. $36 \mathrm{Na}$ votação nominal, os Conselheiros responderão "sim", "não" ou "abstenção" à chamada feita pelo Coordenador da mesa, que anotará as respostas e proclamará o resultado final. Parágrafo único. A folha de votação ficará arquivada na Secretaria-Executiva"

190 “Art. 39 Cada Conselheiro, na condição de titular, terá direito a um voto, não sendo aceitos votos por procuração. Art. 40 Ressalvados os casos em que se exija quórum especial, o quórum de deliberação do Conselho é de maioria simples, respeitado o quórum de instalação."

"Art. 37 Será considerada aprovada a matéria que obtiver a maioria dos votos favoráveis, salvo nos casos em que o número de abstenções for maior que o somatório dos votos favoráveis e contrários ou nos casos especiais previstos neste Regimento, observado sempre o quórum mínimo da Sessão Plenária."

191 “Art. 15 O CNS reunir-se-á, ordinariamente, doze vezes por ano e, extraordinariamente, de ofício, por convocação do Presidente ou por deliberação do Plenário, a requerimento de qualquer Conselheiro. $\S 1^{\circ} \mathrm{O}$ calendário do ano subsequente será definido na Reunião Ordinária ou Extraordinária do mês de dezembro. $\S 2^{\circ} \mathrm{O}$ quórum de instalação do Conselho é de maioria absoluta. $3^{\circ}$ Cada membro terá direito a um voto."

192 "Art. 39 Cada Conselheiro, na condição de titular, terá direito a um voto, não sendo aceitos votos por procuração. Art. 40 Ressalvados os casos em que se exija quórum especial, o quórum de deliberação do Conselho é de maioria simples, respeitado o quorum de instalação. $\S 1^{\circ}$ Quando for verificada falta de quórum para deliberar, será suspensa a sessão até recomposição do quórum necessário. $\S 2^{\circ}$ Persistindo a falta de quórum por duas horas, o Presidente ou o Coordenador da Sessão Plenária fará o seguinte encaminhamento: I - se a votação exigir quórum especial e tiver apenas maioria simples, a matéria será remetida para a reunião subseqüente, devendo ser prioritariamente 
É importante lembrar que no momento da proclamação do resultado pelo Presidente, ocorre a especificação das abstenções e votos favoráveis e contrários, como previsto no Regimento, em seu art. $38^{193}$.

Tais deliberações tomam a forma de moções, recomendações ou resoluções, na forma do art. 57 do Regimento Interno ${ }^{194}$. As moções são a forma de o CNS manifestar a aprovação, repúdio ou reconhecimento a algum assunto, na forma do art. $60{ }^{195}$. As recomendações, por sua vez, abordam temas que não sejam de responsabilidade direta do Conselho, mas que sejam relevantes a sujeitos de quem se espere determinada conduta. Representam, desta forma, sugestões e advertências a tais instituições, com previsão no art. 59 do Regimento Interno ${ }^{196}$. Já as Resoluções, previstas no art. 58 do Regimento Interno, são atos gerais, de caráter normativo, que passam pela homologação pelo Ministro de Estado e Saúde e publicação no Diário Oficial da União, em até trinta dias de sua aprovação. Caso isso não ocorra, a Resolução deve retornar ao CNS para ser analisada novamente em Plenário, juntamente com justificativa e proposta de alteração. O Pleno, por sua vez, pode revogar, modificar a Resolução ou mantê-la, que deverá ser encaminhada novamente ao Ministro para homologação. Na hipótese de o Ministro

apreciada, dando-se prosseguimento à Sessão Plenária para discussão dos outros itens da pauta, se houver; e II - se a matéria exigir deliberação por maioria simples e não tiver quórum, a sessão será encerrada, devendo a matéria não votada ser apreciada, prioritariamente, na reunião subseqüente."

193، "Art. 38 Terminada a votação, o Presidente proclamará seu resultado, especificando os votos favoráveis e os contrários e as abstenções.”

194 “Art. 57 As deliberações do CNS, observado o quórum estabelecido são consubstanciadas em: I Resolução; II - Recomendação; e III - Moção. Parágrafo único. As deliberações podem ser apresentadas durante a ordem do dia por qualquer Conselheiro, por escrito ou verbalmente, sendo identificadas de acordo com o seu tipo e numeradas correlativamente após aprovação."

195 "Art. 60 A Moção é uma forma de manifestar aprovação, reconhecimento ou repúdio a respeito de determinado assunto ou fato."

196 “Art. 59 A Recomendação é uma sugestão, advertência ou aviso a respeito do conteúdo ou forma de execução de políticas e estratégias setoriais ou sobre a conveniência ou oportunidade de se adotar determinada providência. Parágrafo único. As Recomendações serão sobre temas ou assuntos específicos que não seja habitualmente de responsabilidade direta do CNS, mas que são relevantes e necessários dirigidos a sujeitos institucionais de quem se espera ou se solicita determinada conduta ou providência." 
novamente não homologar a Resolução, nem manifestar-se sobre a mesma, o Plenário deverá encaminhá-la. Isso porque é necessário lembrar que somente o Plenário do Conselho tem o condão de revogar qualquer Resolução por ele aprovada ${ }^{197}$. Isso nos leva ao entendimento de que o Plenário do CNS não estaria submetido a controle pelo Ministro de Estado, já que se vislumbra situação na qual, novamente, ocorre procedimento análogo ao do Congresso Nacional, neste caso, ao sistema de sanção e veto. Esta é questão controversa, pois, com a previsão de um sistema na qual há possibilidade de "rejeição do veto" do Ministro de Estado, e consequentemente, da ausência de controle legalmente prevista, em última instância, pelo Ministro de Estado, é enfraquecida uma possível legitimidade indireta do CNS através do Ministro e do Chefe do Executivo. Contudo, cabe lembrar, novamente, que o próprio Ministro de Estado foi responsável por homologar as disposições do Regimento Interno. Nesse sentido, restam dúvidas quanto ao efetivo controle do Ministro de Estado sobre o CNS, o que enfraquece, reitera-se, uma possível alegação de legitimidade indireta desta instância colegiada.

\footnotetext{
197 “Art. 58 A Resolução é ato geral, de caráter normativo. § $1^{\text {o }}$ A redação da Resolução obedecerá às determinações contidas no Manual de Redação da Presidência da República e no Decreto $n^{\circ} 4.176$, de 28 de março de 2002. $\S 2^{\circ}$ As deliberações do CNS serão assinadas pelo seu Presidente e aquelas consubstanciadas em Resoluções e homologadas pelo Ministro de Estado da Saúde serão publicadas no Diário Oficial da União - DOU, no prazo máximo de trinta dias, após sua aprovação. $\S 3^{\circ} \mathrm{A}$ Resolução aprovada pelo CNS que não for homologada pelo Ministro de Estado da Saúde, no prazo de até trinta dias após sua aprovação, deverá retornar ao Plenário do CNS na reunião seguinte, acompanhada de justificativa e proposta alternativa, se de sua conveniência, para avaliação do Pleno que poderá acatar as justificativas revogando, modificando ou mantendo a Resolução que, nos dois últimos casos, será reencaminhada ao Ministro para homologação. $\S 4^{\circ}$ Se novamente o Ministro de Estado da Saúde não homologar a Resolução, nem se manifestar sobre esta em até trinta dias após o seu recebimento, ela retornará ao Plenário do CNS para os devidos encaminhamentos. $\S 5^{\circ}$ As Resoluções do Conselho Nacional de Saúde somente poderão ser revogadas pelo Plenário.”
} 


\section{CAPÍTULO IV - ATRIBUIÇÃO NORMATIVA DO CNS ATINENTE ÀS PESQUISAS CIENTÍFICAS ENVOLVENDO SERES HUMANOS}

Neste Capítulo será abordada a questão central deste estudo, qual seja, a regulamentação, promovida pelo órgão colegiado analisado no capítulo anterior, das pesquisas científicas no ordenamento jurídico brasileiro. Após a investigação do ato normativo no qual se consubstancia tal regulamentação, da importância de tais direitos para o momento histórico vivido pela sociedade, e à luz de todas as considerações acerca do princípio da legalidade e as novas concepções sobre juridicidade, o objetivo será discutir se a atribuição normativa em pauta encontra-se harmonizável à ordem constitucional instituída em 1988 e à legitimidade necessária a um Estado Democrático.

\section{I - Resolução 196/96}

Em âmbito mundial, a necessidade de regulamentação de pesquisas envolvendo seres humanos foi reconhecida após a $2^{\circ}$ Guerra Mundial, em decorrência das violações ocorridas nos campos de concentração. Neste cenário foi desenvolvido o Código de Nuremberg, no qual, segundo José MARQUES FILHO, foi oficialmente reconhecido o princípio da autonomia, responsável ainda por afirmar a indisponibilidade do consentimento voluntário, entre outros ${ }^{198}$. Em 1964, o Código de Nuremberg foi revisto na $18^{\text {a }}$

\footnotetext{
${ }^{198}$ MARQUES FILHO, José. Ética em pesquisa: dez anos da resolução CNS 196/96. Rev. Bras. Reumatol., São Paulo, v. 47, n. 1, Feb. 2007 . Disponível em $<\mathrm{http} / / /$ www.scielo.br/scielo.php?script=sci_arttext\&pid=S048250042007000100002\&lng=en\&nrm=i so $>$. Accessado em 16 de outubro de 2012.
} 
Assembleia da Associação Média Mundial, culminando na aprovação da Declaração de Helsinque, responsável por uma ampliação do código revisto ${ }^{199}$.

A Declaração de Helsinque, por sua vez, passou por revisões, nas quais foram sendo integradas noções interessantes à proteção dos indivíduos submetidos a procedimentos científicos. $\mathrm{Na}$ revisão ocorrida em Tóquio, em 1975, foi incluída na Declaração de Helsinque a necessidade de instituição de comitês para fiscalização ética de projetos envolvendo pesquisas com seres humanos. Em 2000, na revisão da Declaração ocorrida em Edimburgo tal ideia tornou-se exigência para qualquer pesquisa a ser realizada, inspiração para a posterior regulamentação brasileira, responsável por criar os Comitês de Ética em Pesquisa, já abordados ${ }^{200}$.

Ainda, o Council for International Organization of Medical Sciences (Cioms), aliado à Organização Mundial da Saúde (OMS), elaborou as "Diretrizes Internacionais para Pesquisa Biomédica com Seres Humanos", representando um documento de proteção aos sujeitos de pesquisa mais aprofundado do que os anteriores ${ }^{201}$.

A Resolução 196/96, já referida e anexa, é uma das normas de regulamentação atual atinente à questão das pesquisas científicas envolvendo seres humanos no ordenamento jurídico brasileiro. Aliada à Resolução na missão de garantir os direitos dos indivíduos envolvidos em pesquisas encontra-se, em âmbito nacional, a Lei Orgânica de Saúde, a Carta dos Direitos dos Usuários de Saúde, portarias do Ministério da Saúde e Resoluções da ANVISA. Assim, chega-se à conclusão que as pesquisas científicas realizadas no país devem obedecer tais normas, além daquelas de contexto internacional,

\footnotetext{
${ }^{199}$ HARDY, Ellen et al . Comitês de Ética em Pesquisa: adequação à Resolução 196/96. Rev. Assoc. Med. Bras., São Paulo, v. 50, n. 4, Dec. 2004 . Disponível em $<\mathrm{http}$ :/www.scielo.br/scielo.php?script=sci_arttext\&pid=S010442302004000400040\&lng=en\&nrm=i so $>$. Accessado em 16 de outubro 2012.

${ }^{200}$ Ibid..

${ }^{201}$ MARQUES FILHO, José. Op. Cit.
} 
dentre as quais destacamos a Resolução nº 129/1996 do MERCOSUL/GMC, referida na Resolução 196/96. Contudo, é necessário salientar que, tratando-se de normatização nacional, a Resolução 196/96 representa o documento com mais profundidade na defesa dos direitos dos sujeitos de pesquisa.

A Resolução retromencionada, no entanto, não foi a primeira preparada pelo Ministério da Saúde no tema observado. Isso porque, além do Código de Ética Médica de 1988 e do Código de Deontologia Médica de 1984, o próprio CNS, em sua antiga conjuntura, já havia sido responsável por estabelecer normas para tal atividade científica, na Resolução $n^{\circ} 1$ de 18 de junho de 1988 . De acordo com SÔNIA VIEIRA, foi proposta uma revisão à Resolução $n^{\circ} 1$ de 1988 ao Conselho Nacional de Saúde, que culminou na formação de um Grupo de Trabalho e na consulta de aproximadamente trinta mil pessoas. Desta forma, no I Congresso Brasileiro de Bioética, em 1996, foi aprovada a versão preliminar da Resolução $196^{202}$.

É necessário salientar que o Grupo de Trabalho criado pelo CNS de forma a revisar as normas previstas na Resolução $n^{\circ} 1$ de 1988 era formado por representantes de distintas áreas profissionais e sociais, incluindo representantes dos usuários ${ }^{203}$. O resultado deste trabalho foi a publicação da Resolução CNS nº 196, de 10 de outubro de 1996, que, segundo as palavras do coordenador do GT, professor Dr. William Saad Hossne, "não é cartorial, estatutária ou código. Ela é um instrumento que obriga a análise bioética dos projetos de pesquisa. Sem ser lei, tem força legal, sem ser coercitiva, é consistente para flexibilização com responsabilidade.(grifamos) "204. É preciso lembrar também, como já referido, da existência de um novo GT e da realização de eventos, posteriores a

\footnotetext{
${ }^{202}$ VIEIRA, Sonia. Ética e metodologia na pesquisa médica. Rev. Bras. Saude Mater. Infant., Recife, v. 5, n. 2, June 2005 . Disponível em $<$ http://www.scielo.br/scielo.php?script=sci_arttext\&pid=S151938292005000200013\&lng=en\&nrm=iso>. Acessado em 16 de Out. 2012.

${ }^{203}$ MARQUES FILHO, José. Op. Cit.

${ }^{204}$ Apud MARQUES FILHO, José. Op. Cit.
} 
ocorrência de consulta pública, que visam à discussão de propostas de forma a concretizar uma revisão da Resolução 196/96.

O preâmbulo da Resolução, além de estabelecer os documentos que fundamentaram a mesma, traz os quatro principais referenciais que direcionaram todo o desenvolvimento do ato normativo, quais sejam autonomia, não maleficência, beneficência e justiça. Ademais, dispõe sobre o objetivo da mesma, que é garantir tanto os direitos, quanto os deveres dos sujeitos de pesquisa, dos pesquisadores e do próprio Estado.

Outrossim, a Resolução em pauta, além de dispor sobre a CONEP e os CEP' s como já visto, estabelece definições de termos correlatos ao tema da Resolução dentre os quais destacamos a definição de pesquisa, pesquisador responsável, risco da pesquisa, dano associado ou decorrente da pesquisa, indenização, vulnerabilidade e incapacidade. Dispõe também, em seu item III, sobre o atendimento a exigências éticas e científicas que toda a pesquisa envolvendo seres humanos deve preencher, e no que implica tal eticidade exigida. Estabelece os requisitos para o atendimento ao consentimento livre e esclarecido e os parâmetros para que determinada pesquisa seja admitida, tendo em vista seus riscos e benefícios. A Resolução 196 esclarece ainda sobre a responsabilidade dos pesquisadores e a co-responsabilidade do CEP que aprovou o projeto.

Desta forma, torna-se claro que, ainda que seja a Resolução omissa em relação a possíveis sanções aplicáveis aos pesquisadores e aos CEP' s, ela é responsável por estabelecer obrigações aos pesquisadores e aos CEP' s. A Resolução representa, nesse sentido, um instrumento fundamental ao atual cenário de omissão legislativa quanto ao tema, na proteção dos direitos fundamentais daqueles submetidos às pesquisas científicas. 


\section{II - Relevância dos direitos}

A situação em tela demonstra, deste modo, que a regulamentação acerca das pesquisas científicas encontra-se hoje reunida na Resolução 196/96 do Conselho Nacional de Saúde. Ou seja, a regulamentação de um direito deveras relevante na atual conjuntura, chamado por muitos de direitos de $4^{\mathrm{a}}$ Geração, não está sendo encarada pelo poder democraticamente encarregado da função normatizante, o Poder Legislativo.

É necessário salientar que a importância de tais direitos no momento atual reside inicialmente no crescente número de pesquisas científicas, com produção de novas técnicas e, até mesmo, manipulação genética. Deve-se ter em mente que as pesquisas científicas são responsáveis por melhorar as condições de saúde e, consequentemente, melhorar a qualidade de vida e a longevidade das pessoas. Ainda, como salientado pela especialista em Bioética, LUANA PALMIERI FrANÇA PAGANI, possuem impacto até mesmo no desenvolvimento econômico e social do país ${ }^{205}$. É inegável, desta forma, sua importância para a sociedade e para o mundo, uma vez que, também ressaltado pela especialista, a saúde e o desenvolvimento social representam objetivos centrais dos governos, de acordo com a Declaração Universal sobre Bioética e Direitos Humanos. ${ }^{206}$ No entanto, também não se deve negar que aliado a tal avanço, os indivíduos submetidos a tais pesquisas, os sujeitos de pesquisa, não podem ser negligenciados. Assim, a mão do direito deve estar presente de forma que o conhecimento científico da humanidade não seja impedido de prosperar e, ao mesmo tempo, a ambição do homem por conhecimento seja limitada por padrões éticos de conduta. Isso porque a evolução da sociedade

205 PAGANI, Luana Palmieri França. A condução de pesquisas clínicas e os usuários do sistema público de saúde. $\quad$ Disponível em $<$ http://www.agu.gov.br/sistemas/site/PaginasInternas/NormasInternas/AtoDetalhado.aspx?idAto=268 266\&ID_SITE=>. Acessado em 20 de outubro de 2012.

${ }^{206}$ Ibid. 
traz inevitavelmente consigo a necessidade de evolução do direito, concedendo este aos indivíduos garantias suficientes para respeito aos seus direitos fundamentais. Assim explica-se a inclusão, por alguns autores, da engenharia genética como a Quarta Geração de Direitos.

Isto posto, a pergunta que o presente estudo pretende discutir, é: a regulamentação acerca das pesquisas científicas consubstanciada na Resolução 196/96 encontra respaldo na Constituição Federal de 1988? E ainda, será essa regulamentação suficiente para garantir os chamados Direitos de $4^{\mathrm{a}}$ Geração aos indivíduos?

\section{III - Atribuição normativa do Conselho Nacional de Saúde e o Estado Democrático de Direito}

Diante de todo o exposto no Capítulo I do presente trabalho, vislumbrouse a ampliação do princípio da legalidade, diante das exigências sociais. É inegável que o Estado Democrático de Direito exige que certos parâmetros sejam atendidos de forma a consolidar os direitos fundamentais, no entanto, este não pode servir de entrave quando, à guisa de consolidar tais direitos, e na observância de parâmetros claros, sejam propostas novas leituras constitucionais. Nesse sentido, cabe analisar em qual medida a atribuição normativa do referido Conselho está adequada a esta nova concepção acerca da legalidade e se atende aos requisitos mínimos de democracia e legitimidade. Para isso, será feita inicialmente a análise da Resolução 196/96 à luz de suposições acerca da medida de sua adequação à lei, ou seja, serão abordados, caso a caso, argumentos que confirmem ou rechacem a ideia de ser a Resolução um ato normativo secundum legem, praeter legem ou ainda contra legem. 


\section{III. 1 - Resolução 196/96 e sua possível adequação à lei}

Inicialmente, é importante relembrar que a atribuição do CNS decorre de mandamento constitucional, ao estabelecer, entre outras, a atribuição de promover o desenvolvimento científico e realizar o controle e físcalização de procedimentos de interesse para a saúde ao Sistema Único de Saúde, no referido art. 200 da Carta Magna. Desta forma, sendo o Conselho órgão integrante da estrutura do SUS, a atribuição lhe é também devida. Ademais, a Lei 8.080 de 1990 , em seu art. $6^{\circ}$, dispôs atribuição ao SUS análoga ao determinado pela Constituição Federal da República, além de determinar em seu art. 15, ser competência da União, em âmbito administrativo, a elaboração de normas técnico-científicas de promoção, proteção e da saúde e de promoção da articulação com entidades representativas da sociedade civil, para a definição e controle dos padrões éticos para a pesquisa, ações e serviços de saúde. A estas se seguiu a Lei 8.142 de 28 de dezembro de 1990, que definiu ser competência do CNS a formulação de estratégias e controle da execução da política de saúde.

Isto posto, em uma das análises possíveis, vislumbra-se situação na qual os dispositivos legais são deveras abrangentes, sendo incapazes de esmiuçar de qual forma e em qual extensão tais atribuições se darão. Como salientado por ALEXANDRE SANTOS DE ARAGÃO, e mencionado neste trabalho no Capítulo II, hipótese como esta poderia indicar inconstitucionalidade na lei com conteúdo aberto. Assim, antes de partirmos à denúncia do ato normativo da Administração Pública, deve-se buscar a delação da base normativa deste ato administrativo $^{207}$.

${ }^{207}$ ARAGÃO, Alexandre Santos de. Op. Cit. 
Cabe lembrar que, neste caso, poderia ser entendido que a atividade normativa das pesquisas científicas encontra-se englobada nas atribuições dotadas ao SUS, ou seja, que, de forma a realizar as atividades previstas em mandamento constitucional, a normatividade se faz consequente, momento no qual aclama-se a Teoria dos Poderes Implícitos ${ }^{208}$. O princípio da hermenêutica constitucional em comento poderia ser aplicado caso se entendesse que a atividade normativa encontra-se inserida na atribuição do SUS de controlar procedimentos de interesse para a saúde e de incrementar o desenvolvimento científico, previstos, respectivamente nos incisos I e V do art. 200 da Constituição da República. Fortalecendo tal ideia estaria o fato de inexistência de lei que possibilite tanto o controle quanto o incremento de atividades científicas. Desta forma, não haveria outra saída ao CNS, como sujeito responsável por tal tarefa dentro da estrutura do Sistema Único de Saúde, além de criar normas de forma a viabilizar sua atribuição. Estimulando ainda mais tal linha de pensamento, estaria o fato de o art. 15 da Lei 8.080 de 1990, referida linhas acima, conferir ao âmbito administrativo da União a responsabilidade de definir os padrões éticos para pesquisas, atribuição que só teria efetividade caso fosse, como o é, consubstanciada em ato normativo.

Em hipótese de não se entender por violação de lei, a Resolução em comento seria, desta forma, secundum legem ${ }^{209}$. Isso porque, além da disposição constitucional, as leis em que se baseia a atribuição do SUS e do CNS conferir-lhes-ia poderes suficientes à realização de atividade normativa das pesquisas científicas, ainda que assim tivessem feito de forma

\footnotetext{
${ }^{208}$ OLIVEIRA, Rafael Carvalho Rezende Op. cit.. p. 83. E ainda: “(...) (1) poderes decorrentes ou emergentes (resulting powers): os poderes que derivam de uma leitura conjunta de todos ou alguns dos poderes conferidos especificamente pela constituição; (2) poderes implícitos (implied powers): poderes não expressamente mencionados na constituição, mas adequados à prossecução dos fins e tarefas constitucionalmente atribuídos aos órgãos de soberania; (3) poderes inerentes ou essenciais (inherent or essential powers), poderes pertinentes e indispensáveis ao exercício de funções políticas soberanas." (CANOTILHO, J.J. Gomes. Op. cit. p. 548.)

${ }^{209}$ BINENBOJM, Gustavo. Op. Cit. p. 142.
} 
demasiadamente abrangente, com generalidade e abstração, e, em algumas hipóteses, inovando na ordem jurídica. Caso fosse postulada a inconstitucionalidade destas bases legais do regulamento em análise, dever-seia, numa interpretação sistemática da Constituição e tendo em vista a irradiação dos comandos da Carta Magna no tocante à garantia dos direitos fundamentais, defender sua constitucionalidade. Enquadrando-se perfeitamente, nesta suposição, o exercício de atividade secundum legem, ou seja, baseada em lei devidamente constitucional. Tampouco haveria inconstitucionalidade ou ilegalidade da Resolução já que a mesma estaria devidamente em concordância com os postulados constitucionais, o que será analisado a fundo mais adiante. A conclusão a que se chegaria nesta conjectura, seria a de que a Resolução assume forma de regulamento de execução, apenas detalhando uma atribuição legal. Contudo, segundo as lições de AlEXANDRE SANTOS DE ARAGÃO, poderia-se afirmar que a Resolução 196/96 assume forma de regulamento independente, responsável por disciplinar a parte principal da matéria, estando esta, contudo, prevista em lei 210

Outras proposições que poderiam ser feitas são: primeiro, que a Resolução 196/96 representaria espécie de regulamento praeter legem e, segundo, se o ato normativo em comento seria espécie de regulamento contra legem.

\section{III. 2 - Resolução 196/96: Ato normativo praeter legem?}

Quanto à primeira tese, poderia ser considerado que as atribuições previstas em lei, e até mesmo na Constituição, não dariam suporte jurídico a atribuição normativa do Conselho atinente às pesquisas científicas. Nesse

${ }^{210}$ ARAGÃO, Alexandre Santos de. Op. Cit.. 
sentido, ainda que não se questionasse a violação a qualquer lei, a normatização das pesquisas científicas pelo CNS estaria indo além do que permitido legalmente. Tal julgamento poderia ocorrer porque em nenhum momento a Constituição ou as leis 8.080/90 e 8.142/90 concedem atribuição normativa ao Conselho Nacional de Saúde no tocante a este tema jurídico moral-sensível específico que são as pesquisas científicas envolvendo seres humanos $^{211}$.

De forma a combater esta possível crítica à Resolução, devemos ter em mente todo o disposto no Capítulo I acerca da ampliação do princípio da legalidade. Neste momento de constitucionalização do direito, o apego ao legalismo estrito não é mais bem-vindo. O que se defende, nesse sentido, é que seja respeitada a irradiação dos comandos constitucionais para todos os demais ramos do direito, neste caso, ao Direito Administrativo. Para isso, alude-se a duas das formas de constitucionalização do Direito, pensadas por LOUIS FAVOREAU, quais sejam, o da constitucionalização-juridicização e da constitucionalização-transformação. A primeira representa a ideia que a Constituição não mais exerce uma função política, ou seja, ocorre um processo de juridicização do texto constitucional. A segunda, por sua vez, representa justamente a irradiação dos preceitos constitucionais sobre os ramos do direito, mencionada linhas acima. Aliada a tais espécies, o autor listou ainda outra forma de constitucionalização, a chamada constitucionalização-elevação. Segunda esta terceira concepção da constitucionalização do direito, diversas

\footnotetext{
${ }^{211}$ A expressão utilizada diz respeito a "assuntos que envolvem concretização ou restrição a Direitos Fundamentais, justamente aqueles em que as discordâncias de posicionamento na sociedade são mais intensas e para os quais a Constituição não oferece respostas objetivas." GONÇALVES, Artur Pessoa; COLARES, Ana Cecília Sabbá; MENEZES, Tainá Passos de. Os limites e os padrões das atividades normativas do conselho federal de medicina em temas jurídico-morais sensíveis no estado constitucional brasileiro. $\quad$ Disponível em $\quad<$ http://www.pucrio.br/pibic/relatorio_resumo2011/Resumos/CCS/JUR/JURAna\%20Colares\%20Artur\%20Gon\%C3\% A7alves\%20Tain\%C3\%A1\%20Menezes.pdf> . Acessado em 24 de outubro de 2012.
} 
matérias, que anteriormente eram encaradas por lei ou por regulamentos, passam a ser normatizadas através da Constituição.

Os efeitos destas noções seriam a simplificação da ordem jurídica e a unificação dela. Isso porque, em primeiro lugar, seria deixado de lado o legalismo extremo, já que a lei não mais estaria no centro do ordenamento jurídico, sendo este ocupado pela Constituição. Ademais, a Constituição tornase o verdadeiro fundamento de validade de todo ato normativo e todo ramo do direito ${ }^{212}$. Assim, ainda que se considere que o CNS, enquanto órgão da Administração Pública, não possui atribuição legal específica no tocante à normatização das pesquisas científicas envolvendo seres humanos, deve-se ter em mente se o mesmo adequa-se ao sistema de direitos fundamentais e ao sistema democrático, chamado por BINENBOJM de vetores axiológicos da Constituição. Isto nos leva à questão de investigar se a Resolução 196/96 encontra respaldo na Constituição Federal de 1988, que será abordada posteriormente $^{213}$.

Sobre a constitucionalização do direito, e como já mencionado no Capítulo II, o autor defende exatamente a noção da Constituição representando o eixo da atividade administrativa e a consolidação da juridicidade administrativa ${ }^{214}$. A juridicidade adquiriu proporção tão abrangente, que hoje é também utilizada de forma a direcionar a revisão da discricionariedade administrativa. Isso porque a juridicidade é responsável por determinar a aplicação direta dos princípios constitucionais sobre os atos administrativos não vinculados por lei. Deste modo, e como já fora mencionado através das lições de CANOTILHO em crítica à chamada legalidade estritamente formal, não

\footnotetext{
${ }^{212}$ FAVOREAU, Louis. "La constitutionnalisation du droit". In; AUBY, Jean-Bernard. et al. L'unité du droit: mélange en hommage à Roland Drago. Paris: Econômica, 1996. Apud OLIVEIRA, Rafael Carvalho Rezende. Op. Cit. p. 30.

${ }^{213}$ BINENBOJM, Gustavo. Op. Cit. p. 71

${ }^{214}$ BINENBOJM, Gustavo. Op. Cit. p. 36
} 
há espaço decisório da Administração alheio às amarras do direito ${ }^{215}$. Por esta razão, BINENBOJM formulou uma ordem de prioridade para o controle jurisdicional destes atos discricionários, a seguir relacionados.

Inicialmente, e em um controle rígido, o juiz deve dar preferência à proteção dos direitos fundamentais, consequência da constitucionalização de direitos neste estudo abordada. O segundo critério é aquele que impõe ao juiz um controle mais severo quanto maior o grau de objetividade do ato normativo. Ademais, deverá ser dada preferência à legitimidade de investidura da autoridade, em relação a matérias políticas, e à especialização técnicofuncional da autoridade, quando tratar-se de matérias que exijam experiência e expertise, nos quais deverá ocorrer um controle mais brando. Por último, o grau de participação social nos processos decisórios também seria responsável por direcionar a um controle mais brando ${ }^{216}$. Na questão abordada, da normatização das pesquisas científicas envolvendo seres humanos, através da Resolução 196/96, há a proteção dos direitos fundamentais, há grande objetividade no ato normativo e, sem dúvidas, há participação social, evidenciada através da composição paritária presente no CNS, o que levaria a um controle dotado de rigidez intermediária. Falta observar, no entanto, o terceiro critério, qual seja, de especialização técnico-funcional da autoridade da qual emanou o ato normativo.

Tal ponto remete à obrigação de investigar mais precisamente a discricionariedade técnica, margem de escolha baseada em conhecimentos científicos extrajurídicos, do Conselho. Quanto a isto, deve-se projetar a noção de que a composição do CNS, além da presença de grupo de usuários, conta também com profissionais da saúde, aqui incluída a comunidade científica, representantes do governo, prestadores de serviço e profissionais de saúde, o

\footnotetext{
${ }^{215}$ CANOTILHO, J. J. Gomes. Op. cit. p.728. Já mencionada no Capítulo I.

${ }^{216}$ BINENBOJM, Gustavo. Op. Cit. p. 241.
} 
que evidencia, como já mencionado, a expertise destas decisões, dado o inegável conhecimento técnico destes Conselheiros. Ademais, a participação de representantes do governo remete a decisões mais conscientes em termos políticos, já que o pragmatismo, que é muitas vezes necessário a políticas públicas, será também observado. Desta forma, tal como afirmado por BINENBOJM em relação às agências reguladoras, pode-se considerar, com os devidos ajustes à situação enfrentada, que existe uma comunicação entre a racionalidade técnica e a racionalidade jurídico-política no CNS ${ }^{217}$.

Prosseguindo com suas ilações, caberia considerar que o Conselho, tal como as agências reguladoras, é também local de se "submeter os processos de gestão dos interesses da coletividade ao aprendizado do instrumental técnico." 218 Por esta razão, pode-se afirmar que o Conselho, ao reunir o conhecimento técnico ao político, e à luz dos interesses da sociedade, representado pelo grupo dos usuários, produz decisões que vão além da pura discricionariedade técnica e possuem irrefragável qualidade. É necessário atentar para o fato de que tal discricionariedade só justifica-se caso esteja alicerçada sobre a legalidade e a legitimidade ${ }^{219}$. Como já exposto neste estudo, a legalidade é principio que passa por período de ampliação de seu sentido, o que, mais uma vez, possibilitaria a confirmação do exercício de atividade discricionária da administração pública, ainda que, na linha de considerações deste tópico, para além da lei. A outra vertente balizadora da discricionariedade para realizar a atividade normativa em comento, a legitimidade, será analisada mais adiante, no tópico referente à adequação constitucional da Resolução.

\footnotetext{
${ }^{217}$ BINENBOJM, Gustavo. Op. Cit. p. 304.

${ }^{218}$ Ibidem, p. 304.

219 MOREIRA NETO, Diogo de Figueiredo. Curso de Direito Administrativo: parte introdutória, parte geral e parte especial. $14^{\text {a }}$ Ed. Rio de Janeiro: Forense, 2005. p. 98.
} 


\section{III. 3 - Violações à lei na Resolução 196/96}

Chega-se, neste momento, a dúvida a cerca da existência na Resolução 196/96 de violações legais, o que nos levaria a crer que o mesmo representaria espécie de regulamento contra legem. Um dos argumentos neste sentido, seria de violação ao disposto no Código Civil, em seu art. 11, quando este estabelece a proibição de limitação voluntária aos direitos de personalidade, o que indicaria ilegalidade não só da Resolução 196/96 quanto da própria realização de pesquisas científicas ${ }^{220}$. Mais aplicável ainda à questão aqui abordada, seria o art. 13 do mesmo diploma legal, que trata sobre a proibição de atos de disposição do próprio corpo ${ }^{221}$. Tais dispositivos tratam da profunda questão de disponibilidade de direitos fundamentais, algo que não é o objetivo principal do presente trabalho. O objetivo, neste momento, é apenas apontar quais os direitos em jogo e a atual solução à situação. Hoje, considera-se que a proibição do Código Civil seria irreal, ao considerarmos o momento histórico, e, até mesmo, inconstitucional, devido à restrição exacerbada de liberdades definidas pela constituição e também pela violação do princípio da legalidade, já que, para os indivíduos a liberdade é a regra, e não a exceção ${ }^{222}$.

Ainda que não se apegue de forma obstinada à inconstitucionalidade de tal dispositivo, preza-se pela ponderação entre direitos, valendo-se do cotejo, neste caso, entre a disponibilização do próprio corpo, e logicamente, o enfraquecimento de "posições jurídicas subjetivas de direitos fundamentais,

\footnotetext{
220 Art. 11 do Código Civil: "Art. 11. Com exceção dos casos previstos em lei, os direitos da personalidade são intransmissíveis e irrenunciáveis, não podendo o seu exercício sofrer limitação voluntária."

${ }^{221}$ Art. 13 do Código Civil: Art. 13. "Salvo por exigência médica, é defeso o ato de disposição do próprio corpo, quando importar diminuição permanente da integridade física, ou contrariar os bons costumes. Parágrafo único. $\mathrm{O}$ ato previsto neste artigo será admitido para fins de transplante, na forma estabelecida em lei especial."

${ }^{222}$ MARTEL, Letícia de Campos Velho. Sujeitos de pesquisa no ordenamento jurídico brasileiro: um exame civil-constitucional da autolimitação de direitos fundamentais. Disponível em < $\mathrm{http}: / /$ works.bepress.com/cgi/viewcontent.cgi?article=1000\&context=leticia_martel >. Acesso em 27 de outubro de 2012.
} 
especialmente relacionadas à integridade psicofísica, à saúde e à privacidade”, com limites claros definidos na Resolução, e o avanço científico que possibilitará, em última instância, o desenvolvimento da saúde. A partir de lições de JORGE ReIS NOVAES, LetíCIA DE CAMPOS VElHO MARTEL, propôs padrões para que a disposição de tais direitos seja admitida, a saber: a) modalidade da renúncia; b) qualidade do consentimento; c) sujeitos da relação de disposição; d) proteção de direitos de terceiros; e) dimensão e natureza do direito fundamental; f) dignidade humana; g) postulados normativos, principalmente a proporcionalidade ${ }^{223}$.

Desta forma, leva-se a crer que, havendo limites rígidos que protejam os indivíduos de violações à sua dignidade, as pesquisas, e tão logo, limitações voluntárias a direitos, devem ser permitidas, como já o são em muitas partes do mundo. Seguindo tal linha de raciocínio, a Resolução não só não seria ilegal, como também seria fundamental, por representar o único instrumento no ordenamento jurídico brasileiro responsável por estabelecer os critérios éticos das pesquisas e, dessa forma, viabiliza-las.

Deve ser observado, desta maneira, o cumprimento otimizado do sistema de princípios da constituição, que passa a ser analisado com mais detalhamento a seguir.

\section{III. 4 - Resolução $196 / 96$ e sua adequação aos ditames constitucionais}

Quanto à questão de respaldo ou não da Resolução na CRFB de 1988, faz-se também necessário tecer certos comentários de forma a elucidá-la. BINENBOJM determinou com maestria que "o sistema de direitos fundamentais e o princípio democrático, tal como delineados na Constituição, exercem também influência

223 Ibid. 
decisiva na definição dos contornos da atividade administrativa. À centralidade desses pilares constitutivos e legitimadores da ordem constitucional deve corresponder uma igual centralidade na organização e funcionamento da Administração Pública." ${ }^{224}$ Nesse sentido, é importante que seja investigado se a Resolução 196/96 ajusta-se a tais vetores, o que passa-se a realizar.

Como já mencionado, a Resolução em observação não dispôs sobre sanções aplicáveis a possíveis transgressores dos direitos dos sujeitos de pesquisa no curso de pesquisa científica, e nem poderia, já que, caso o fizesse, verificar-se-ia espécie de flagrante inconstitucionalidade, com violação ao art. $5^{\circ}$, inciso XXXIX, pois haveria limitação a direito fundamental. Ainda que pudesse se pensar em desrespeito à liberdade em realizar pesquisas científicas e de livre iniciativa dos fomentadores de pesquisas, retorna-se neste ponto, a ideia de que seria desumano pensar em denunciar um ato normativo que visa, incontestavelmente, a proteção da dignidade da pessoa humana, frente ao direito dos pesquisadores de exercerem suas atividades sem limitações e destes fomentadores de lucrar com isto. Desta forma, partindo da proporcionalidade, qualquer indivíduo dotado de razoabilidade seria capaz de chegar ao entendimento que diante de um embate entre a dignidade daqueles sujeitos de pesquisa e da liberdade dos pesquisadores, a ponderação, sem dúvidas, prezaria pela primeira. É certo que as obrigações previstas na Resolução 196/96, não foram dispostas de forma a enfraquecer qualquer direito fundamental, mas tão só para fortalecê-los, impedindo uma eventual violação aos mesmos. Neste sentido é possível rechaçar a noção de desrespeito ao art. $5^{\circ}$, inciso II da Carta Magna.

Deve-se observar que as obrigações dispostas em Resolução são de forma a garantir o respeito aos direitos fundamentais. É preciso atentar para o real objetivo constitucional, qual seja, a garantia destes direitos. Isso porque o

\footnotetext{
${ }^{224}$ BINENBOJM, Gustavo. Op. cit. p. 71.
} 
direito à saúde é dever do Estado, como previsto no art. 196 da Constituição Federal. Mais que isto, o direito à vida e tão logo, a dignidade da pessoa humana, fundamento de nossa República, são indissociáveis de tal noção. Desta forma, as políticas públicas, que neste caso são exercidas pelo Sistema Único de Saúde, no qual se inclui o Conselho Nacional de Saúde, devem ser implementadas de forma que os preceitos constitucionais sejam efetivados. Nesse sentido, a atividade normativa exercida pela Administração Pública representa nada mais que a forma de instrumentalizar o exercício de função constitucionalmente definida, em face de vácuo legislativo. Ademais, é importante mencionar, novamente, o respeito à diretriz estabelecida na Carta Magna no tocante à participação da comunidade no SUS e na administração pública direta e indireta, que é atendida pelo CNS através de sua composição paritária.

Esta composição remete à questão da legitimidade, também fundamental ao Estado Democrático de Direito. Como bem salientou DiOGO MoreIRA Neto, quando se define um Estado como Democrático e de Direito está sendo indicado o reconhecimento no mesmo de duas ordens de referência ética, a saber, a ético-jurídica e a ético-política. Tais ordens correspondem, respectivamente, à legalidade e à legitimidade, que representam "disposições estáveis do poder na sociedade". Ainda segundo o autor, a legalidade corresponde à uma estabilização do poder positivado através da coação por normas, enquanto a legitimidade, o que nos importa neste momento, corresponde à estabilização do poder através de valores consensualmente aceitos, o que remete à noção, já mencionada, de baixo nível de coerção do último. É importante ter em mente que legitimidade e legalidade, a par de por muito tempo terem sido vistos com a mesma identidade, não mais o são, como visto na ilação retromencionada. $\mathrm{O}$ fato de a lei ter servido de base para as diversas atrocidades ocorridas durante a Segunda Guerra Mundial, além de ter 
sido, como já referido, uma das razões para a própria crise da lei, foi também responsável pela formulação da distinção entre legalidade e legitimidade ${ }^{225}$.

Desta forma, Diogo MoreIRA NeTO estabelece ainda que o sistema juspolítico deve ser eficiente em aspectos diversos, a seguir referidos, consistindo no ciclo do poder. Os primeiros seriam a destinação e atribuição, que ocorrem através da correta percepção do consenso originário, relacionando-se este à ordem constitucional. Ainda, a eficiência na distribuição e no exercício do poder pela captação do consenso corrente, com ligação ao desempenho das funções do Estado. Por último, estaria a eficiência na contenção e detenção do poder, através da participação nestas funções de Estado ${ }^{226}$. Desta forma, torna-se claro que a legitimidade, juntamente com a legalidade, a par da ampliação do segundo, torna-se a base de todo o ordenamento jurídico.

Seguindo nas lições do autor, a atividade administrativa tem como requisito legal a legitimidade e deve sempre direcionar-se ao interesse público. Ademais, é preciso observar com atenção a afirmação de suma importância para o presente estudo segundo a qual deve o administrador

"aplicar a lei para promover os interesses públicos confiados ao Estado, a legitimidade tanto poderá estar integralmente contida na legalidade, cabendo-lhe, tão-somente, praticar atos vinculados, como apenas parcialmente nela contida, necessitando praticar atos em que lhe caberá fazer, abstrata ou concretamente opções legítimas (Interessenvertre-tung, para Laun)" 227.

Percebe-se, neste sentido, a relativização da legalidade, quando em face de legitimidade inconteste, possibilitada pela ascensão da juridicidade administrativa.

\footnotetext{
${ }^{225}$ OLIVEIRA, Rafael Carvalho Rezende Op. cit. p. 89.

226 MOREIRA NETO, Diogo de Figueiredo. Legitimidade e Discricionariedade. Novas Reflexões sobre os Limites e Controle da Discricionariedade. $3^{\text {a }}$ Ed. Rio de Janeiro: Forense, 1998. p. 5.

${ }^{227}$ Ibid. p. $25-26$.
} 
Deve-se ter em mente, além disso, que uma das razões do Legislativo ter confirmado sua legitimidade, não obstante a atual revisão a esta noção, é o fato de estarem reunidas em ambas as Casas do Congresso Nacional diversos setores da sociedade, como defendido por CELSO ANTÔNIO BANDEIRA DE MELlo ${ }^{228}$, o que evidencia a ideia de participação da sociedade nas decisões, já que estas partem de seus representantes. Essa questão é também atendida no Conselho Nacional de Saúde, devido a sua composição e à realização de consultas públicas, como a ocorrida de forma a receber propostas visando à revisão da Resolução 196/96.

Verifica-se, neste caso, a exemplo de outras instituições públicas nas quais foi reacendido o envolvimento da sociedade, que a presença de democracia participativa no Conselho é um forte indício de sua legitimidade, em atendimento ao art. $37, \S 3^{\circ}$ da Constituição Federal. Desta feita, o Conselho representaria um exemplo deste processo de releitura da atividade estatal, que prescinde cada vez mais de celeridade e técnica, na chamada democratização da Administração Pública. Esta nova forma de atendimento ao interesse da sociedade, com a própria inclusão desta no processo de tomada de decisões, obedece, como afirmado por RAFAEL OLIVEIRA, ao princípio da participação, retirado da interpretação do art. $1^{\circ}$ da Carta Magna ${ }^{229}$.

Outrossim, a composição do Conselho vai além, já que une a participação da sociedade à expertise de profissionais, fruto de sua composição paritária abordada no Capítulo III. Logo, é notório que a constitucionalização do direito e a crise da lei possuem ligação direta com esta nova faceta da Administração Pública, na qual há a participação da sociedade, sem que seja esquecido o conhecimento técnico, necessário a uma gama extensa de

\footnotetext{
${ }^{228}$ MELLO, Celso Antônio Bandeira de. Op. cit. p. 363-364. A questão da crise da democracia representativa foi abordada no Capítulo I e representa, justamente, a descrença na ideia que os parlamentares representam os interesses da sociedade e que a lei corresponda à tais interesses. Sobre a questão ver: OLIVEIRA, Rafael Carvalho Rezende Op. cit.. p.112.

${ }^{229}$ OLIVEIRA, Rafael Carvalho Rezende Op. cit.. p. 117-118.
} 
matérias, na qual inclui-se a questão das pesquisas científicas envolvendo seres humanos aqui estudada. Isto indica uma nova concepção até mesmo do direito, em que se configura inserida esta tendência de aprofundamento da participação do Executivo na função legislativa ${ }^{230}$. Esta tendência tem ligação ainda, com a tentativa de se encontrar uma alternativa ao déficit democrático do sistema representativo, como afirma RAFAEL OLIVEIRA ${ }^{231}$.

Contudo, de forma a enfraquecer a ideia de legitimidade do CNS estaria o fato, já abordado, de ausência de controle expressamente previsto pelo Ministro de Estado, o que poderia nos levar a crer que o Conselho Nacional de Saúde possui uma atuação independente, sem controle por um órgão hierarquicamente superior na Administração Pública. Argumento em posição contrária à de ilegitimidade do Conselho Nacional de Saúde seria de que, apesar de um processo de controle não estar previsto, o ato normativo em comento e o próprio Regimento Interno do Conselho foram devidamente aprovados pelo Ministro, que demonstrou, desta forma, sua anuência aos mesmos. Aliado a isso, deve-se ter em mente outras duas noções, mencionadas a seguir. A primeira delas é a noção que a Administração Pública, não se encontra alheia à apreciação de sua adequação à ordem jurídica, algo que é reforçado pela juridicidade, como fora abordado no Capítulo II. A outra ideia que reforça uma corrente favorável à legitimidade do CNS é da existência, devido a sua própria composição e dinâmica decisória, de um controle prévio consubstanciado exatamente na participação de representantes da sociedade na tomada de decisões.

\footnotetext{
230 "Está agonizando um conceito de lei, um tipo de parlamento e uma determinada concepção do direito. O parlamento monopolizador da atividade legiferante do Estado sofreu abalos. Deve continuar legislando, é certo. Porém, a função legislativa será, no Estado contemporâneo, dividida com o Executivo. O parlamento não deve deixar de reforçar o seu poder de controle sobre os atos, inclusive normativos, do Executivo." (CLÈVE, Clèmerson Merlin. Atividade legislativa do poder executivo. $2^{\mathrm{a}}$ Edição. São Paulo: Revista dos Tribunais, 2000. p.57).

${ }^{231}$ OLIVEIRA, Rafael Carvalho Rezende Op. cit.. p. 109.
} 
$\mathrm{O}$ atendimento ao princípio democrático é também elucidado através de noções já abordadas sentido, aproveitando-se para isso de argumentos de validação da atividade das agências reguladoras. Como afirmado por BINENBOJM, a solução de questões através de noções técnicas e profissionais, representa uma forma de prática democrática, algo que existe no Conselho Nacional de Saúde em decorrência de sua composição, que leva a uma discricionariedade técnica. Ademais, todo o disposto acerca da participação da sociedade e da abertura desta instância colegiada a indivíduos que nem mesmo façam parte da estrutura do CNS, através de consultas públicas ou de envio de sugestões, é outro argumento que confirma o respeito ao princípio em análise. Para que não reste dúvida, é preciso salientar que a democracia não deve se confundir com a decisão da maioria, mas sim um "projeto de exercício de autogoverno coletivo em que as deliberações sociais se realizam ao longo do tempo" ${ }^{232}$.

Isto posto, atenta-se para o fato que o cenário para a discussão foi devidamente exposto. $\mathrm{O}$ presente trabalho não visa à defesa ou denúncia da atividade exercida pelo Conselho Nacional de Saúde. O real objetivo é justamente de aclarar as questões envolvidas nesta situação tão controversa e possibilitar o debate, ainda ínfimo, acerca da "tensão latente com o princípio da legalidade" desta atribuição ${ }^{233}$. A conclusão a que o estudo pode chegar é a irrefragável noção que os direitos fundamentais não podem ser negligenciados, algo que ocorreria caso fosse promovida uma delação à Resolução 196/96, sem a devida e concomitante atuação legislativa. Sobre uma possível denuncia à Resolução, é importante lembrar que o judiciário poderia exercer o controle através de Ação Civil Pública, ou, tratando-se de controle abstrato, por ADPF.

\footnotetext{
${ }^{232}$ BINENBOJM, Gustavo. Op. cit. p. 303-304.

${ }^{233}$ BINENBOJM, Gustavo. Op. cit. p. 264-265. Importante lembrar que a expressão foi originalmente utilizada pelo autor em relação à agências reguladoras, das quais, novamente pega-se de empréstimos determinadas considerações.
} 
O que se propõe, no entanto, para diminuir discussões tão extensas acerca da atribuição normativa do CNS, é a produção legislativa acerca do tema com a expressa menção à atividade normativa na específica questão das pesquisas científicas envolvendo seres humanos. Neste sentido, uma saída possível seria a definição dos chamados princípios inteligíveis, já mencionados neste estudo, e consagrado pela Suprema Corte dos Estados Unidos da América. Esta teoria defende a delegação legislativa quando a lei dispuser acerca dos parâmetros necessário ao ato normativo infra-legal para que este possa sofrer um controle mais intenso, a partir da observância ou não destes "standards" de conteúdo definidos na lei. Ou seja, a vinculação aos parâmetros legais seria a razão de um controle mais denso desta atividade administrativa. Não obstante o entendimento de impossibilidade de delegação legislativa, para além dos casos expressamente definidos na Constituição, a delegação a partir da definição de princípios inteligíveis vem sendo aceita pela doutrina e também considerada pela jurisprudência ${ }^{234}$.

Contudo, ainda que se possam discutir questões jurídicas sobre a Resolução, é irrefragável a qualidade de tal instrumento, corroborada até mesmo pela existência de Projeto de Lei com redação idêntica à do ato normativo emanado do $\mathrm{CNS}^{235}$. Desta feita, a mera denúncia a Resolução 196, em termos práticos nada resolveria, já que a mesma possui a função, diga-se de passagem de maneira exclusiva na ordem jurídica brasileira, de padronizar a

\footnotetext{
${ }^{234}$ OLIVEIRA, Rafael Carvalho Rezende. Op. Cit. p.49-50. Ademais, de forma a exemplificar a aceitação em jurisprudência da doutrina dos princípios inteligíveis, em discussão da ADI 4568/DF, Rel Ministra Cármen Lúcia, a doutrina em tela foi mencionada pelo Ministro Luiz Fux ao considerar que a utilização de princípios inteligíveis seria responsável por criar um "diálogo institucional que busca colher frutos das virtudes dos dois Poderes políticos".

235 Projeto de Lei $\mathrm{n}^{\circ}$ 2473/2003. Disponível em $<$ http://www.camara.gov.br/proposicoesWeb/prop_mostrarintegra;jsessionid=36CF37EBC3A1D46EE 2B1D7B2E495A532.node1? codteor $=180212 \&$ filename $=P L+2473 / 2003>$. Acessado em 26 de outubro de 2012.
} 
atividade dos administradores e dos envolvidos nas pesquisas em tela, como afirmado por ALEXANDRE SANTOS DE ARAGÃO ${ }^{236}$.

Continuando nesta audaciosa sugestão, defende-se que o cenário ideal, de fato, seria o de lei dispondo sobre o tema, até mesmo para que fosse possível a previsão de sanções e, mais, da criminalização de certas condutas no âmbito das pesquisas científicas envolvendo seres humanos, algo que já existe, cabe lembrar, para as pesquisas científicas envolvendo as demais espécies animais. Este cenário torna-se, desta maneira, cada vez mais anômalo para um ordenamento jurídico pautado na defesa e na promoção dos direitos fundamentais, que se vê, nesta situação, enfraquecido.

${ }^{236}$ ARAGÃO, Alexandre Santos de. Op. Cit. v. 256. 


\section{v - CONCLUSÕES FINAIS}

Todo o exposto neste estudo visa instigar a discussão acerca da atribuição normativa do Conselho Nacional de Saúde. Desta maneira, partiu-se da investigação acerca das mudanças de leitura do princípio da legalidade, para que tal discussão se fizesse possível. Assim, primeiro foi necessário entender a importância dos princípios para o direito administrativo, consubstanciada esta justamente na falta de uniformidade deste ramo do direito. No momento em que reconhecemos este caráter das normas administrativas, torna-se mais fácil a compreensão de que os princípios funcionam como unificador, conferindo segurança jurídica ao direito administrativo. Foi abordada então a normatividade dos princípios, desenvolvida por PAULO BONAVIDES, com o exame acerca das três fases da mesma. Conclui-se, que na terceira fase, a póspositivista, consistindo esta em um momento de verdadeira busca de aproximação entre o direito e moral, os princípios são encarados como verdadeiras normas, servindo até mesmo de baliza para controle de constitucionalidade. O pós-positivismo e a questão da normatividade dos princípios tiveram grande influência na releitura da legalidade estrita no âmbito do direito administrativo.

Ademais, foi realizada uma análise acerca da origem do princípio da legalidade, representando consequência do surgimento do liberalismo e do princípio da separação de poderes, bases também do Estado Democrático de Direito. Para exame do princípio em tela, foram mencionadas as concepções para o mesmo formuladas por EISENMANN, as quais são sintetizadas por ALEXANDRE SANTOS DE ARAGÃO da seguinte forma:

1. A primeira delas seria a noção de mera não-contrariedade à lei, existindo liberdade em hipótese de vácuo legislativo. 
2. A segunda concepção prioriza uma habilitação formal da competência para atuação da administração, estando ela proibida de atuar caso não exista lei prévia habilitadora.

3. A terceira possível forma de se vislumbrar o princípio da legalidade, seria a exigência de uma norma prévia não somente habilitadora, mas que determine o conteúdo da atividade administrativa.

4. A quarta leitura determina que a lei prévia deve ordenar a prática de determinada atividade, não apenas estabelecer uma atuação facultativa, e esgotar o contéudo de tal atividade. Nessa visão não há qualquer espaço para a descricionariedade administrativa.

Não obstante os diversos sentidos que o princípio pode obter e as respectivas críticas, ele é concebido atualmente em duas concepções abarcadas pelo ordenamento jurídico brasileiro, quais sejam, o princípio da prevalência de lei e o princípio da reserva de lei. Assim, na primeira, também chamada de reserva negativa, a legalidade seria uma limitação para a atividade administrativa, caso existisse uma lei sobre a matéria. Já a segunda, também denominada de reserva positiva de lei, indica que a lei seria requisito prévio à atuação do administrador, consistindo a lei em uma autorização da atividade administrativa.

Esta concepção está passando por um momento de revisão, no qual ocorre sua substituição pela noção de juridicidade administrativa, segundo a qual todo o ordenamento representa a fundamentação da atividade administrativa, e não somente lei em sentido estrito. Tal processo ocorreu devido a alterações na ordem jurídica, tais quais, a crise da lei, a constitucionalização do Direito e o pós-positivismo. 
As razões para a crise da lei, por sua vez, seriam a inflação legislativa, a noção de que a lei nem sempre é justa e pode ser responsável por alicerçar barbáries, como a Segunda Guerra Mundial, a fundamentação de atos administrativos por normas infra-legais, além do controle do Poder Executivo sobre o Legislativo. Juntamente a isto, a constitucionalização do direito também consolidou a noção de que a Constituição Federal é a verdadeira diretriz das atividades a serem exercidas pela Administração Pública. Segundo BINENBOJM, a adoção do sistema dos direitos fundamentais e do sistema democrático promoveu esta alteração no papel exercido pelas Constituições nos ordenamentos jurídicos. Foi então ressaltado, neste momento, a importância da chamada filtragem constitucional, desenvolvida por PAULO RICARDO SCHIER, na qual o ordenamento jurídico passa por uma releitura à luz dos ditames constitucionais. Essas noções, juntamente com a ascensão da normatividade dos princípios ocasionada pelo pós-positivismo, levaram a uma revisão acerca da rigidez do princípio da legalidade. Desse modo, o princípio da legalidade foi englobado pela juridicidade administrativa, já que, neste momento, não é mais possível conceber a ideia de que a somente a lei será capaz de conferir segurança jurídica à sociedade. Assim, foi consolidada a noção de que todo o bloco de legalidade, incluindo este outras regras e também princípios do ordenamento jurídico, devem balizar a atividade administrativa.

Esta nova concepção do princípio da legalidade gera tanto uma maior liberdade para a Administração Pública atuar, mesmo em face de omissão de lei em sentido estrito, quanto um maior controle de tais atividades, uma vez que estas devem estar de acordo com todo o ordenamento jurídico, possibilitando o controle até mesmo daqueles atos discricionários.

A situação em tela levantou uma discussão em relação à possibilidade de existência de atos administrativo para além e ainda contra a lei. Contrariando parte da doutrina, BINENBOJM defende a possibilidade de prática de ato praeter legem e contra legem pela Administração Pública, 
sempre que esta esteja pautada em mandamentos constitucionais e ocorra de forma a ampliar ou garantir direitos fundamentais. Assim, mesmo que certo ato seja ilegal, ele pode vir a ser validado, através da convalidação ou sanatória, caso se adeque aos parâmetros formulados pelo autor.

Foram também abordadas as características da lei e dos regulamentos além as razões apontadas pela doutrina tradicional que apontam para a superioridade da primeira sobre a segunda, que indicaram a influência do princípio da legalidade.

Quanto ao poder regulamentar, foi apontada a divergência acerca dos termos regulamentação e regulação, já que, para grande parte da doutrina a regulamentação seria exercida exclusivamente pelo Chefe do Executivo, com a expedição de decretos executivos. Neste sentido, a regulação seria uma atividade meramente técnica, exercida pelo restante da Administração Pública. Tal ideia foi rechaçada por BINENBOJM defendendo este que o poder regulamentar é aquele exercido não só pelo Chefe do Executivo, mas também pelos órgãos reguladores. Assim, a diferença entre ambos seria apenas o âmbito de aplicação, sendo este geral para os atos expedidos pelo Chefe do Executivo. $\mathrm{O}$ autor baseou-se, para isto, no princípio da eficiência, na noção de uma Administração Pública policêntrica e na previsão constitucional de delegação de funções às agências reguladoras, constante do artigo 174 da Constituição Federal da República.

Outrossim, a partir do conceito de regulamento e de suas classificações, chegou-se a ideia de que não há que se falar em regulamento totalmente executivo, já que, em maior ou menor escala, todo ordenamento inova na ordem jurídica, já que isso faz parte de seu papel concretizador. Desta maneira, além da distinção histórica e a que distingue ato regulamentar de $1^{\circ}$ grau e ato regulamentar de $2^{\circ}$ grau, foi abordada a diferença entre regulamentos de execução e regulamentos autônomos. Apesar desta distinção, como já 
mencionado, inexiste regulamento totalmente executivo, já que cabe a este pormenorizar outra norma e logo, exercer atividade criativa.

Quanto à proibição de edição de regulamentos independentes, por muito tempo defendida, devem ser admitidas ponderações. Atualmente, como já mencionado, todo o ordenamento jurídico passa por uma revisão, com a constitucionalização do direito, dessa forma, em face de atividade pautada na Constituição da República, tais regulamentos podem vir a ser admitidos. A delegação disfarçada, por sua vez, não é admitida pela doutrina brasileira, devido a três razões distintas. A primeira delas seria a noção de que os casos de delegação permitidos já estariam previstos na Constituição, nos artigos 62 e 68 . Ainda, a noção da tripartição de poderes e a regra constante do artigo 25 , inciso I, do Ato das Disposições Constitucionais Transitórias também seriam impeditivos da ocorrência da delegação, até mesmo da deslegificação.

Foram observadas então as formas de controle do poder regulamentar, sobre o qual a juridicidade também exerce influência. Isso porque, como já mencionado, todo e qualquer ato administrativo deve adequar-se ao ordenamento jurídico como um todo, para ser considerado válido. Assim, ainda que não se possa falar em controle de legalidade estrito, é perfeitamente aplicável o controle de juridicidade dos atos praticados pelo Poder Executivo.

No Capítulo III, partiu-se ao esboço do Conselho Nacional de Saúde. Desta maneira, a partir da análise de sua composição, restou clara a existência de democracia participativa no mesmo, devido à representação paritária do grupo dos usuários. Assim, foi possível observar um exemplo, neste caso, do processo de releitura da legitimidade estatal, no qual ocorre a democratização da Administração Pública, com a inserção da sociedade nesta.

Ademais, em consequência da participação de experts como Conselheiros e também de representantes do Governo, foi possível concluir a existência também de discricionariedade técnica no CNS. No entanto, chegouse ao entendimento que a atividade do Conselho vai além da mera 
discricionariedade, isso, presume-se, devido a participação do Governo e de usuários em sua estrutura.

Foi também abordada a dinâmica decisória do Conselho, com a influência do processo decisório do Congresso Nacional, e o funcionamento das Comissões, em especial a CONEP, que retratam uma busca por decisões mais técnicas e aclaradas. Contudo, um ponto restou sem resposta, a saber, a questão do controle dos atos do CNS pelo Ministro da Saúde. Esta dúvida pode indicar um argumento contrário à legitimidade do Conselho, no entanto, cabe lembrar que tanto o Regimento Interno do Conselho, quanto a Resolução 196/96, contaram com a aprovação do Ministro. Ainda, conclui-se que a participação de representantes da sociedade também indica uma espécie de controle prévio, ao qual, reitera-se, pode-se seguir a qualquer momento o controle do Poder Judiciário. Isso porque, como mencionado, também como consequência da constitucionalização do direito administrativo, todo ato da Administração Pública deve adequar-se à ordem jurídica como um todo, e não mais somente à lei.

Quanto à atribuição do Conselho, chegou-se a conclusão que a mesma decorreria, em princípio da Constituição da República, do art. $1^{\circ}$, inciso III, em defesa da dignidade da pessoa humana. Ainda, decorre do direito à saúde e do direito à vida. Decorreria também dos artigos 196 e 197 da Carta Magna, ao definir que a saúde é dever do Estado, cabendo a este dispor sobre a regulamentação, controle e fiscalização das ações e serviços de saúde. Ainda, a atribuição tem ligação com as atribuições do Sistema Único de Saúde, previstas no art. 200 da Constituição da República, uma vez que o CNS constitui instância colegiada do mesmo.

Além de disposições constitucionais, a atribuição do Conselho também está presente nas Leis 8.080/90 e 8.142/90 e no Decreto 5839/2006. Contudo, a grande controvérsia é justamente o fato de nenhum desses dispositivos 
mencionarem expressamente a atribuição do CNS de normatizar no tocante as pesquisas científicas envolvendo seres humanos.

Desta maneira, e partindo da compreensão das razões de ser tal direito deveras relevante para a ordem jurídica, tornou-se possível o levantamento de três hipóteses distintas acerca da atividade exercida.

A primeira delas é que em uma interpretação alargada dos dispositivos que conferem atribuição ao Conselho e tendo em visto os objetivos constitucionais, a Resolução poderia ser considerada um regulamento secundum legem, entendimento reforçado pela Teoria dos Poderes Implícitos.

A segunda hipótese seria de que a Resolução consiste em regulamento praeter legem, já que não se enquadraria nas atribuições previstas no ordenamento jurídico brasileiro. Como forma de defender a constitucionalidade da Resolução nesta hipótese, estaria todo o disposto acerca da ampliação da legalidade administrativa, tendo em vista a constitucionalização do direito, uma vez que trata-se de regulamento que visa a defesa de direitos fundamentais.

A última hipótese levantada seria a de que a Resolução consubstanciaria regulamento contra legem, isso porque violaria, por exemplo, os arts. 11 e 13 do Código Civil. De forma a rechaçar tal entendimento estaria o contexto social balizado por um cumprimento otimizado do sistema de princípios da Carta Magna. Desta maneira, através da imposição de limites claros, realizada pela Resolução 196/96, a limitação voluntária de direitos poderia ser aceita.

A parte final do presente estudo foi dedicada à discussão acerca da correspondência ou não da atribuição normativa em tela aos ditames constitucionais. Partiu-se da análise do atendimento ao princípio democrático e princípio da legitimidade, essenciais a um Estado chamado Democrático de Direito.

Quanto ao atendimento a legitimidade, pode-se observar que a participação da sociedade, como mencionado, fortalece esta noção, já que 
corresponde a uma alternativa ao déficit democrático do sistema representativo. Aliado a isto, estaria a ideia de que as decisões do Conselho partem não só da sociedade, como também de experts, outra razão de inegável qualidade em suas decisões. De forma contrária, não obstante a ideia de controle prévio dos usuários Conselheiros e de controle jurisdicional, estaria o fato da ausência de controle do Ministro de Saúde definido de forma expressa.

A composição do Conselho, já que esta conta com a participação de especialistas na área de Saúde é argumento de respeito ao princípio democrático. Corroborando ainda mais esta ideia estaria o fato do Conselho, além de contar com participação de representantes dos usuários, estar aberto à participação da sociedade como um todo, através da realização de consultas públicas e também de envio de sugestões.

A questão de atendimento aos direitos fundamentais foi também analisada, sendo possível chegar a conclusão que a ponderação de direitos leva a uma defesa da Resolução 196/96, já que restou comprovada que os benefícios ocasionados pela mesma são imensamente maiores que a mera limitação a liberdade dos pesquisadores e fomentadores das pesquisas.

Isto posto, as sugestões finais consistem na ideia que a Resolução 196/96 consiste em documento fundamental ao ordenamento jurídico brasileiro no momento atual, a saber, de omissão legislativa no tocante as pesquisas científicas envolvendo seres humanos. Desta maneira, defendeu-se que a mera denuncia à Resolução nada resolveria, pelo contrário, apenas negligenciaria ainda mais os direitos dos sujeitos de pesquisa. Contudo, a produção legislativa é também fundamental de forma que seja fortalecida esta proteção, visando a cominação de sanções e a efetiva promoção da dignidade da pessoa humana, fundamento desta Pátria amada. 


\section{Bibliografia}

ABREU, Jorge Manuel Coutinho de. Sobre os Regulamentos Administrativos e o Princípio da Legalidade. Coimbra: Almedina, 1987. 131- 177 p.

ARAGÃo, Alexandre Santos de. A Concepção Pós-Positivista do Princípio da Legalidade, in Revista de Direito Administrativo, v. 256.

ÁVILA, Humberto. Repensando o "Principio do Interesse Público sobre o Particular”. Revista Diálogo Jurídico, Salvador, CAJ - Centro de Atualização Jurídica, v. I, n ${ }^{\circ} 7$, outubro, 2001. Disponível em: www.direitopublico.com.br. Acessado em 28 set. 2012.

BARROSO, Luis Roberto e BARCELlos, Ana Paula de. O Começo da História. A nova Interpretação Constitucional e o Papel dos Princípios no Direito Brasileiro. Biblioteca Digital Fórum Administrativo - Direito Público -FA. Belo Horizonte: Fórum. Ano 4. No 37, 2004.

BARROSO, Luís Roberto. Interpretação e Aplicação da Constituição:

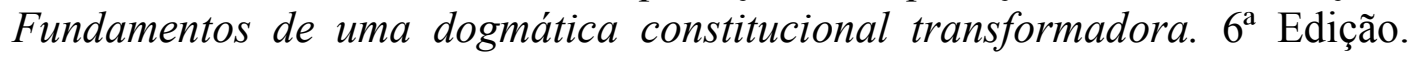
São Paulo: Saraiva, 2004. 427 p.

BARROSO, Luís Roberto. Neoconstitucionalismo e Constitucionalização do Direito (o triunfo tardio do Direito Constitucional no Brasil). Revista de Direito Administrativo ${ }^{\mathrm{o}}$ 240, 2005. 137-179 p.

BINENBOJM, Gustavo. Uma teoria do Direito Administrativo: Direitos Fundamentais, Democracia e Constitucionalização. $2^{\text {a }}$ edição. Rio de Janeiro: Renovar, 2008. 340 p.

BOBBIO, Norberto. A Era dos Direitos. Tradução de Carlos Nelson Coutinho; apresentação de Celso Lafer. Nova Edição. Rio de Janeiro: Elsevier, 2004. 232 p.

BOBBIO, Norberto. Teoria do Ordenamento Jurídico. $5^{\mathrm{a}}$ Edição. São Paulo: UNB, 1994. 184 p.

BONAVIDES, Paulo. Curso de Direito Constitucional. 26a Edição. São Paulo: Malheiros, 2011.835 p.

CANOtilho, J. J. Gomes. Direito Constitucional e Teoria da Constituição. $6^{\text {a }}$ Edição. Coimbra: Almedina, 2003. 1522 p. 
CARVALHO FILHO, José dos Santos. Manual de Direito Administrativo. $21^{\mathrm{a}}$ Edição. Rio de janeiro: Lumen Juris, 2009. 1177 p.

CLÈVE, Clèmerson Merlin. Atividade legislativa do poder executivo. $2^{\mathrm{a}}$ Edição. São Paulo: Revista dos Tribunais, 2000.

COHN, Amelia. O Sistema Unificado e Descentralizado da Saúde: descentralização ou desconcentração? P. 56. Disponível em $<$ http://www.cedec.org.br/files_pdf/Osistemaunificadoedescentralizadodesaude .pdf>. Acesso em 15 out. 2012.

CORREIA, José Manuel Sérvulo. Legalidade e Autonomia Contratual nos Contratos Administrativos. Coimbra: Livraria Almedina, 1987. 18- 55 p.

CORTÊS, Soraya Maria Vargas. Conselhos e Conferências de Saúde: papel institucional e mudança nas relações entre Estado e sociedade. In Participação, Democracia e Saúde/ Sonia Fleury e Lenaura de Vasconcelos Costa Lobato (organizadoras) - Rio de Janeiro: Cebes, 2009.

CORTÊS, Soraya Vargas. Sistema Único de Saúde: espaços decisórios e a arena política de saúde. Cad. Saúde Pública, Rio de Janeiro, v. 25, n. 7, Julho 2009 .

DALLARI, Dalmo de Abreu. Elementos de Teoria Geral do Estado. 28 Edição, São Paulo: Saraiva, 2009. 314 p.

DI PIETRO, Maria Sylvia Zanella. Direito Administrativo. $18^{\text {a }}$ Edição. São Paulo: Atlas, 2005. 765 p.

EISENMANN, Charles. O Direito Administrativo e o Principio da Legalidade. In Revista de Direito Administrativo, v. 56.

GONÇALVES, Artur Pessoa; COLARES, Ana Cecília Sabbá; MENEZES, Tainá Passos de. Os limites e os padrões das atividades normativas do conselho federal de medicina em temas jurídico-morais sensiveis no estado constitucional brasileiro. Disponível em $<\mathrm{http} / /$ www.pucrio.br/pibic/relatorio_resumo2011/Resumos/CCS/JUR/JURAna\%20Colares\%2 0Artur\%20Gon\%C3\%A7alves\%20Tain\%C3\%A1\%20Menezes.pdf> . Acesso em 24 out. 2012.

HARDY, Ellen et al . Comitês de Ética em Pesquisa: adequação à Resolução 196/96. Rev. Assoc. Med. Bras., São Paulo, v. 50, n. 4, Dec. 2004 . Disponível 
em<http://www.scielo.br/scielo.php?script=sci_arttext\&pid=S0104423020040 00400040\&lng=en\&nrm=iso $>$. Acesso em 16 out. 2012.

KELSEN, Hans. Teoria Pura do Direito. $6^{\mathrm{a}}$ Ed. São Paulo: Martins Fontes, 2000. 427 p.

LUCHMANN, Lígia Helena Hahn. Participação e representação nos conselhos gestores e no orçamento participativo. Cad. CRH, Salvador, v. 21, n. 52, Abr. 2008. Disponível em $<$ http://www.scielo.br/scielo.php?script $=$ sci_arttext\&pid=S0103497920080001 $00007 \& \operatorname{lng}=\mathrm{en} \& \mathrm{nrm}=\mathrm{iso}>$. Acesso em 23 de Out. de 2012.

MARQUES FILHO, José. Ética em pesquisa: dez anos da resolução CNS 196/96. Rev. Bras. Reumatol., São Paulo, v. 47, n. 1, Feb. 2007 . Disponível em<http://www.scielo.br/scielo.php?script=sci_arttext\&pid $=$ S0482500420070 $00100002 \& \operatorname{lng}=$ en\&nrm=iso $>$. Acesso em 16 out. de 2012.

MARTEL, Letícia de Campos Velho. Sujeitos de pesquisa no ordenamento jurídico brasileiro: um exame civil-constitucional da autolimitação de direitos fundamentais. Disponível em $<\mathrm{http}$ ///works.bepress.com/cgi/viewcontent.cgi?article $=1000 \&$ context $=$ leticia martel>. Acesso em 27 out. 2012.

MEDAUAR, Odete. Direito Administrativo Moderno. $7^{\mathrm{a}}$ Edição. São Paulo: RT, 2003. 509 p.

MEIRELLES, Hely Lopes. Direito Administrativo brasileiro. $18^{\mathrm{a}}$ edição. São Paulo: Malheiros, 1993. 701 p.

MELLO, Celso Antônio Bandeira de. Curso de Direito Administrativo. 26 ${ }^{\text {a }}$ Edição. São Paulo: Malheiros, 2009. 1102 p.

MELLO, Oswaldo Aranha Bandeira de. Princípios Gerais de Direito

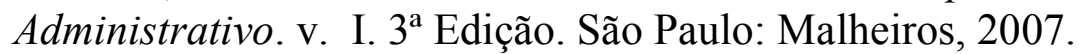

MENDES, Gilmar Ferreira; COELHO, Inocêncio Mártires; BRANCO, Paulo Gustavo Gonet. Curso de Direito Constitucional. 5 ${ }^{\mathrm{a}}$ Edição. São Paulo: Saraiva, 2010. $1616 \mathrm{p}$.

MOREIRA NETO, Diogo de Figueiredo. Curso de Direito Administrativo: parte introdutória, parte geral e parte especial. $14^{\mathrm{a}}$ Ed. Rio de Janeiro: Forense, 2005. 667 
MOREIRA NETO, Diogo de Figueiredo. Legitimidade e Discricionariedade. Novas Reflexões sobre os Limites e Controle da Discricionariedade. $3^{\mathrm{a}}$ Ed. Rio de Janeiro: Forense, 1998. 103 p.

MOREIRA NETO, Diogo de Figueiredo. Mutações do Direito Administrativo. Rio de Janeiro: Renovar, 2000. 300 p.

NOVAIS, Jorge Reis. Contributo para uma teoria do Estado de Direito. Coimbra: Almedina, 2006.

OLIVEIRA, Rafael Carvalho Rezende. A Constitucionalização do Direito Administrativo. O Princípio da Juridicidade, a Releitura da Legalidade Administrativa e a Legitimidade das Agências Reguladoras. Rio de Janeiro: Lumen Juris, 2009. 192 p.

PAGANI, Luana Palmieri França. A condução de pesquisas clínicas e os usuários do sistema público de saúde. Disponível em $<$ http://www.agu.gov.br/sistemas/site/PaginasInternas/NormasInternas/AtoDet alhado.aspx?idAto=268266\&ID_SITE=>. Acesso em 20 out. 2012.

SANTAMARÍA PASTOR, Juan Alfonso. Princípios de Derecho Administrativo. v. I. $3^{\text {a }}$ Edição. Madrid: Centro de Estudios Ramón Areces, S.A, 2000.

SCHEVIBISKI, Renata S.. Regras Institucionais e Processo Decisório de Politicas Públicas: Uma análise sobre o Conselho Nacional de Saúde (19902006). São Paulo, 2007. 130 fls. Dissertação em Programa de Pós-Graduação, Faculdade de Filosofia, Letras e Ciências Humanas, Universidade de São Paulo.

SCHIER, Paulo Ricardo. Filtragem Constitucional: construindo uma nova dogmática jurídica. Porto Alegre: Sergio Antonio Fabris, 1999. 160 p.

SCHIER, Paulo Ricardo. Novos Desafios da Filtragem Constitucional no Momento do Neoconstitucionalismo. In Revista Eletrõnica de Direito do Estado, 2005, n. 4.

SILVA, Frederico Augusto Barbosa da; ABREU, Luiz Eduardo de Lacerda. "Saúde: Capacidade de Luta"- A experiência do Conselho Nacional de Saúde. Instituto de Pesquisa Econômica Aplicada, 2002. 55 p. 
SILVA, José Afonso da. Curso de Direito Constitucional Positivo. $27^{\mathrm{a}}$ Edição. São Paulo: Malheiros, 2006. 924 p.

VIEIRA, Sonia. Ética e metodologia na pesquisa médica. Rev. Bras. Saude Mater. Infant., Recife, v. 5, n. 2, June 2005 . Disponível em $<$ http://www.scielo.br/scielo.php?script=sci arttext\&pid=S1519$38292005000200013 \& \operatorname{lng}=$ en\&nrm=iso $>$. Acesso em 16 out. 2012.

WEFFORT, Francisco. Os clássicos da política. I. 13 ${ }^{\mathrm{a}}$ Ed., $12^{\mathrm{a}}$ reimpressão. São Paulo: $\quad$ Ática, $2005 . \quad 287 \quad$ p. 


\section{Anexo I}

\section{RESOLUÇÃO № 196 DE 10 DE OUTUBRO DE 1996}

O Plenário do Conselho Nacional de Saúde em sua Quinquagésima Nona Reunião Ordinária, realizada nos dias 09 e 10 de outubro de 1996, no uso de suas competências regimentais e atribuições conferidas pela Lei $n^{\circ}$ 8.080 , de 19 de setembro de 1990, e pela Lei $n^{\circ} 8.142$, de 28 de dezembro de 1990, RESOLVE:

Aprovar as seguintes diretrizes e normas regulamentadoras de pesquisas envolvendo seres humanos:

\section{I - PREÂMBULO}

A presente Resolução fundamenta-se nos principais documentos internacionais que emanaram declarações e diretrizes sobre pesquisas que envolvem seres humanos: o Código de Nuremberg (1947), a Declaração dos Direitos do Homem (1948), a Declaração de Helsinque (1964 e suas versões posteriores de 1975, 1983 e 1989), o Acordo Internacional sobre Direitos Civis e Políticos (ONU, 1966, aprovado pelo Congresso Nacional Brasileiro em 1992), as Propostas de Diretrizes Éticas Internacionais para Pesquisas Biomédicas Envolvendo Seres Humanos (CIOMS/OMS 1982 e 1993) e as Diretrizes Internacionais para Revisão Ética de Estudos Epidemiológicos (ClOMS, 1991). Cumpre as disposições da Constituição da República Federativa do Brasil de 1988 e da legislação brasileira correlata: Código de Direitos do Consumidor, Código Civil e Código Penal, Estatuto da Criança e do Adolescente, Lei Orgânica da Saúde 8.080, de 19/09/90 (dispõe sobre as condições de atenção à saúde, a organização e o funcionamento dos serviços correspondentes), Lei 8.142, de 28/12/90 (participação da comunidade na gestão do Sistema Único de Saúde), Decreto 99.438, de 07/08/90 (organização e atribuições do Conselho Nacional de Saúde), Decreto 98.830 , de 15/01/90 (coleta por estrangeiros de dados e materiais científicos no Brasil), Lei 8.489, de 18/11/92, e Decreto 879, de 22/07/93 (dispõem sobre retirada de tecidos, órgãos e outras partes do corpo humano com fins humanitários e científicos), Lei 8.501, de 30/11/92 (utilização de cadáver), Lei 8.974, de 05/01/95 (uso das técnicas de engenharia genética e liberação no meio ambiente de organismos geneticamente modificados), Lei 9.279, de 14/05/96 (regula direitos e obrigações relativos à propriedade industrial), e outras.

Esta Resolução incorpora, sob a ótica do indivíduo e das coletividades, os quatro referenciais básicos da bioética: autonomia, não 
maleficência, beneficência e justiça, entre outros, e visa assegurar os direitos e deveres que dizem respeito à comunidade científica, aos sujeitos da pesquisa e ao Estado.

O caráter contextual das considerações aqui desenvolvidas implica em revisões periódicas desta Resolução, conforme necessidades nas áreas tecnocientífica e ética.

Ressalta-se, ainda, que cada área temática de investigação e cada modalidade de pesquisa, além de respeitar os princípios emanados deste texto, deve cumprir com as exigências setoriais e regulamentações específicas.

\section{II - TERMOS E DEFINIÇÕES}

A presente Resolução, adota no seu âmbito as seguintes definições:

II.1 - Pesquisa - classe de atividades cujo objetivo é desenvolver ou contribuir para o conhecimento generalizável. O conhecimento generalizável consiste em teorias, relações ou princípios ou no acúmulo de informações sobre as quais estão baseados, que possam ser corroborados por métodos científicos aceitos de observação e inferência.

II.2 - Pesquisa envolvendo seres humanos - pesquisa que, individual ou coletivamente, envolva o ser humano, de forma direta ou indireta, em sua totalidade ou partes dele, incluindo o manejo de informações ou materiais.

II.3 - Protocolo de Pesquisa - Documento contemplando a descrição da pesquisa em seus aspectos fundamentais, informações relativas ao sujeito da pesquisa, à qualificação dos pesquisadores e à todas as instâncias responsáveis.

II.4 - Pesquisador responsável - pessoa responsável pela coordenação e realização da pesquisa e pela integridade e bem-estar dos sujeitos da pesquisa.

II.5 - Instituição de pesquisa - organização, pública ou privada, legitimamente constituída e habilitada na qual são realizadas investigações científicas. da pesquisa.

II.6 - Promotor - indivíduo ou instituição, responsável pela promoção

Il.7 - Patrocinador - pessoa física ou jurídica que apoia financeiramente a pesquisa.

II.8 - Risco da pesquisa - possibilidade de danos à dimensão física, psíquica, moral, intelectual, social, cultural ou espiritual do ser humano, em qualquer fase de uma pesquisa e dela decorrente.

II.9 - Dano associado ou decorrente da pesquisa - agravo imediato ou tardio, ao indivíduo ou à coletividade, com nexo causal comprovado, direto ou indireto, decorrente do estudo científico. 
II.10 - Sujeito da pesquisa - é o(a) participante pesquisado(a), individual ou coletivamente, de caráter voluntário, vedada qualquer forma de remuneração.

II.11 - Consentimento livre e esclarecido - anuência do sujeito da pesquisa e/ou de seu representante legal, livre de vícios (simulação, fraude ou erro), dependência, subordinação ou intimidação, após explicação completa e pormenorizada sobre a natureza da pesquisa, seus objetivos, métodos, benefícios previstos, potenciais riscos e o incômodo que esta possa acarretar, formulada em um termo de consentimento, autorizando sua participação voluntária na pesquisa.

II.12 - Indenização - cobertura material, em reparação a dano imediato ou tardio, causado pela pesquisa ao ser humano a ela submetida.

II.13 - Ressarcimento - cobertura, em compensação, exclusiva de despesas decorrentes da participação do sujeito na pesquisa.

II.14 - Comitês de Ética em Pesquisa-CEP - colegiados interdisciplinares e independentes, com "munus público", de caráter consultivo, deliberativo e educativo, criados para defender os interesses dos sujeitos da pesquisa em sua integridade e dignidade e para contribuir no desenvolvimento da pesquisa dentro de padrões éticos.

II.15 - Vulnerabilidade - refere-se a estado de pessoas ou grupos que, por quaisquer razões ou motivos, tenham a sua capacidade de autodeterminação reduzida, sobretudo no que se refere ao consentimento livre e esclarecido.

II.16 - Incapacidade - Refere-se ao possível sujeito da pesquisa que não tenha capacidade civil para dar o seu consentimento livre e esclarecido, devendo ser assistido ou representado, de acordo com a legislação brasileira vigente.

\section{HUMANOS \\ III - ASPECTOS ÉTICOS DA PESQUISA ENVOLVENDO SERES}

As pesquisas envolvendo seres humanos devem atender às exigências éticas e científicas fundamentais.

III.1 - A eticidade da pesquisa implica em:

a) consentimento livre e esclarecido dos indivíduos-alvo e a proteção a grupos vulneráveis e aos legalmente incapazes (autonomia). Neste sentido, a pesquisa envolvendo seres humanos deverá sempre tratá-los em sua dignidade, respeitá-los em sua autonomia e defendê-los em sua vulnerabilidade;

b) ponderação entre riscos e benefícios, tanto atuais como potenciais, individuais ou coletivos (beneficência), comprometendo-se com o máximo de benefícios e o mínimo de danos e riscos; maleficência);

c) garantia de que danos previsíveis serão evitados (não 
d) relevância social da pesquisa com vantagens significativas para os sujeitos da pesquisa e minimização do ônus para os sujeitos vulneráveis, o que garante a igual consideração dos interesses envolvidos, não perdendo o sentido de sua destinação sócio-humanitária (justiça e eqüidade).

III.2- Todo procedimento de qualquer natureza envolvendo o ser humano, cuja aceitação não esteja ainda consagrada na literatura científica, será considerado como pesquisa e, portanto, deverá obedecer às diretrizes da presente Resolução. Os procedimentos referidos incluem entre outros, os de natureza instrumental, ambiental, nutricional, educacional, sociológica, econômica, física, psíquica ou biológica, sejam eles farmacológicos, clínicos ou cirúrgicos e de finalidade preventiva, diagnóstica ou terapêutica.

III.3 - A pesquisa em qualquer área do conhecimento, envolvendo seres humanos deverá observar as seguintes exigências:

a) ser adequada aos princípios científicos que a justifiquem e com possibilidades concretas de responder a incertezas;

b) estar fundamentada na experimentação prévia realizada em laboratórios, animais ou em outros fatos científicos;

c) ser realizada somente quando o conhecimento que se pretende obter não possa ser obtido por outro meio;

d) prevalecer sempre as probabilidades dos benefícios esperados sobre os riscos previsíveis;

e) obedecer a metodologia adequada. Se houver necessidade de distribuição aleatória dos sujeitos da pesquisa em grupos experimentais e de controle, assegurar que, a priori, não seja possível estabelecer as vantagens de um procedimento sobre outro através de revisão de literatura, métodos observacionais ou métodos que não envolvam seres humanos;

f) ter plenamente justificada, quando for o caso, a utilização de placebo, em termos de não maleficência e de necessidade metodológica;

g) contar com o consentimento livre e esclarecido do sujeito da pesquisa e/ou seu representante legal;

h) contar com os recursos humanos e materiais necessários que garantam o bem-estar do sujeito da pesquisa, devendo ainda haver adequação entre a competência do pesquisador e o projeto proposto;

i) prever procedimentos que assegurem a confidencialidade e a privacidade, a proteção da imagem e a não estigmatização, garantindo a não utilização das informações em prejuízo das pessoas e/ou das comunidades, inclusive em termos de auto-estima, de prestígio e/ou econômico - financeiro;

j) ser desenvolvida preferencialmente em indivíduos com autonomia plena. Indivíduos ou grupos vulneráveis não devem ser sujeitos de pesquisa quando a informação desejada possa ser obtida através de sujeitos com plena autonomia, a menos que a investigação possa trazer benefícios diretos aos vulneráveis. Nestes casos, o direito dos indivíduos ou grupos que queiram participar da pesquisa deve ser assegurado, desde que seja 
garantida a proteção à sua vulnerabilidade e incapacidade legalmente definida;

I) respeitar sempre os valores culturais, sociais, morais, religiosos e éticos, bem como os hábitos e costumes quando as pesquisas envolverem comunidades;

m) garantir que as pesquisas em comunidades, sempre que possível, traduzir-se-ão em benefícios cujos efeitos continuem a se fazer sentir após sua conclusão. $O$ projeto deve analisar as necessidades de cada um dos membros da comunidade e analisar as diferenças presentes entre eles, explicitando como será assegurado o respeito às mesmas;

n) garantir o retorno dos benefícios obtidos através das pesquisas para as pessoas e as comunidades onde as mesmas forem realizadas. Quando, no interesse da comunidade, houver benefício real em incentivar ou estimular mudanças de costumes ou comportamentos, o protocolo de pesquisa deve incluir, sempre que possível, disposições para comunicar tal benefício às pessoas e/ou comunidades;

o) comunicar às autoridades sanitárias os resultados da pesquisa, sempre que os mesmos puderem contribuir para a melhoria das condições de saúde da coletividade, preservando, porém, a imagem e assegurando que os sujeitos da pesquisa não sejam estigmatizados ou percam a auto-estima;

p) assegurar aos sujeitos da pesquisa os benefícios resultantes do projeto, seja em termos de retorno social, acesso aos procedimentos, produtos ou agentes da pesquisa;

q)assegurar aos sujeitos da pesquisa as condições de acompanhamento, tratamento ou de orientação, conforme o caso, nas pesquisas de rastreamento; demonstrar a preponderância de benefícios sobre riscos e custos;

r) assegurar a inexistência de conflito de interesses entre o pesquisador e os sujeitos da pesquisa ou patrocinador do projeto;

s) comprovar, nas pesquisas conduzidas do exterior ou com cooperação estrangeira, os compromissos e as vantagens, para os sujeitos das pesquisas e para o Brasil, decorrentes de sua realização. Nestes casos deve ser identificado o pesquisador e a instituição nacionais co-responsáveis pela pesquisa. O protocolo deverá observar as exigências da Declaração de Helsinque e incluir documento de aprovação, no país de origem, entre os apresentados para avaliação do Comitê de Ética em Pesquisa da instituição brasileira, que exigirá o cumprimento de seus próprios referenciais éticos. Os estudos patrocinados do exterior também devem responder às necessidades de treinamento de pessoal no Brasil, para que o país possa desenvolver projetos similares de forma independente;

t) utilizar o material biológico e os dados obtidos na pesquisa exclusivamente para a finalidade prevista no seu protocolo; 
u) levar em conta, nas pesquisas realizadas em mulheres em idade fértil ou em mulheres grávidas, a avaliação de riscos e benefícios e as eventuais interferências sobre a fertilidade, a gravidez, o embrião ou o feto, o trabalho de parto, o puerpério, a lactação e o recém-nascido;

v) considerar que as pesquisas em mulheres grávidas devem, ser precedidas de pesquisas em mulheres fora do período gestacional, exceto quando a gravidez for o objetivo fundamental da pesquisa;

x) propiciar, nos estudos multicêntricos, a participação dos pesquisadores que desenvolverão a pesquisa na elaboração do delineamento geral do projeto; e

z) descontinuar o estudo somente após análise das razões da descontinuidade pelo CEP que a aprovou.

\section{IV - CONSENTIMENTO LIVRE E ESCLARECIDO}

$O$ respeito devido à dignidade humana exige que toda pesquisa se processe após consentimento livre e esclarecido dos sujeitos, indivíduos ou grupos que por si e/ou por seus representantes legais manifestem a sua anuência à participação na pesquisa.

IV.1 - Exige-se que o esclarecimento dos sujeitos se faça em linguagem acessível e que inclua necessariamente os seguintes aspectos:

a) a justificativa, os objetivos e os procedimentos que serão utilizados na pesquisa;

b) os desconfortos e riscos possíveis e os benefícios esperados;

c) os métodos alternativos existentes;

d) a forma de acompanhamento e assistência, assim como seus responsáveis;

e) a garantia de esclarecimentos, antes e durante o curso da pesquisa, sobre a metodologia, informando a possibilidade de inclusão em grupo controle ou placebo;

f) a liberdade do sujeito se recusar a participar ou retirar seu consentimento, em qualquer fase da pesquisa, sem penalização alguma e sem prejuízo ao seu cuidado;

g) a garantia do sigilo que assegure a privacidade dos sujeitos quanto aos dados confidenciais envolvidos na pesquisa;

h) as formas de ressarcimento das despesas decorrentes da participação na pesquisa; e pesquisa.

i) as formas de indenização diante de eventuais danos decorrentes da

IV.2 - O termo de consentimento livre e esclarecido obedecerá aos seguintes requisitos:

a) ser elaborado pelo pesquisador responsável, expressando o cumprimento de cada uma das exigências acima;

b) ser aprovado pelo Comitê de Ética em Pesquisa que referenda a investigação; 
c) ser assinado ou identificado por impressão dactiloscópica, por todos e cada um dos sujeitos da pesquisa ou por seus representantes legais; e

d) ser elaborado em duas vias, sendo uma retida pelo sujeito da pesquisa ou por seu representante legal e uma arquivada pelo pesquisador.

IV.3 - Nos casos em que haja qualquer restrição à liberdade ou ao esclarecimento necessários para o adequado consentimento, deve-se ainda observar:

a) em pesquisas envolvendo crianças e adolescentes, portadores de perturbação ou doença mental e sujeitos em situação de substancial diminuição em suas capacidades de consentimento, deverá haver justificação clara da escolha dos sujeitos da pesquisa, especificada no protocolo, aprovada pelo Comitê de Ética em Pesquisa, e cumprir as exigências do consentimento livre e esclarecido, através dos representantes legais dos referidos sujeitos, sem suspensão do direito de informação do indivíduo, no limite de sua capacidade;

b) a liberdade do consentimento deverá ser particularmente garantida para aqueles sujeitos que, embora adultos e capazes, estejam expostos a condicionamentos específicos ou à influência de autoridade, especialmente estudantes, militares, empregados, presidiários, internos em centros de readaptação, casas-abrigo, asilos, associações religiosas e semelhantes, assegurando-lhes a inteira liberdade de participar ou não da pesquisa, sem quaisquer represálias;

c) nos casos em que seja impossível registrar o consentimento livre e esclarecido, tal fato deve ser devidamente documentado, com explicação das causas da impossibilidade, e parecer do Comitê de Ética em Pesquisa;

d) as pesquisas em pessoas com o diagnóstico de morte encefálica só podem ser realizadas desde que estejam preenchidas as seguintes condições:

- documento comprobatório da morte encefálica (atestado de óbito);

- consentimento explícito dos familiares e/ou do responsável legal, ou manifestação prévia da vontade da pessoa;

- respeito total à dignidade do ser humano sem mutilação ou violação do corpo;

- sem ônus econômico financeiro adicional à família;

- sem prejuízo para outros pacientes aguardando internação ou tratamento;

- possibilidade de obter conhecimento científico relevante, novo e que não possa ser obtido de outra maneira;

e) em comunidades culturalmente diferenciadas, inclusive indígenas, deve-se contar com a anuência antecipada da comunidade através dos seus próprios líderes, não se dispensando, porém, esforços no sentido de obtenção do consentimento individual; 
f) quando o mérito da pesquisa depender de alguma restrição de informações aos sujeitos, tal fato deve ser devidamente explicitado e justificado pelo pesquisador e submetido ao Comitê de Ética em Pesquisa. Os dados obtidos a partir dos sujeitos da pesquisa não poderão ser usados para outros fins que os não previstos no protocolo e/ou no consentimento.

\section{V - RISCOS E BENEFÍCIOS}

Considera-se que toda pesquisa envolvendo seres humanos envolve risco. O dano eventual poderá ser imediato ou tardio, comprometendo o indivíduo ou a coletividade.

V.1 - Não obstante os riscos potenciais, as pesquisas envolvendo seres humanos serão admissíveis quando:

a) oferecerem elevada possibilidade de gerar conhecimento para entender, prevenir ou aliviar um problema que afete o bem-estar dos sujeitos da pesquisa e de outros indivíduos;

b) o risco se justifique pela importância do benefício esperado;

c) o benefício seja maior, ou no mínimo igual, a outras alternativas já estabelecidas para a prevenção, o diagnóstico e o tratamento.

V.2 - As pesquisas sem benefício direto ao indivíduo, devem prever condições de serem bem suportadas pelos sujeitos da pesquisa, considerando sua situação física, psicológica, social e educacional.

V.3 - O pesquisador responsável é obrigado a suspender a pesquisa imediatamente ao perceber algum risco ou dano à saúde do sujeito participante da pesquisa, conseqüente à mesma, não previsto no termo de consentimento. Do mesmo modo, tão logo constatada a superioridade de um método em estudo sobre outro, o projeto deverá ser suspenso, oferecendose a todos os sujeitos os benefícios do melhor regime.

V.4 - O Comitê de Ética em Pesquisa da instituição deverá ser informado de todos os efeitos adversos ou fatos relevantes que alterem o curso normal do estudo.

V.5 - O pesquisador, o patrocinador e a instituição devem assumir a responsabilidade de dar assistência integral às complicações e danos decorrentes dos riscos previstos.

V.6 - Os sujeitos da pesquisa que vierem a sofrer qualquer tipo de dano previsto ou não no termo de consentimento e resultante de sua participação, além do direito à assistência integral, têm direito à indenização.

V.7 - Jamais poderá ser exigido do sujeito da pesquisa, sob qualquer argumento, renúncia ao direito à indenização por dano. $O$ formulário do consentimento livre e esclarecido não deve conter nenhuma ressalva que afaste essa responsabilidade ou que implique ao sujeito da pesquisa abrir mão de seus direitos legais, incluindo o direito de procurar obter indenização por danos eventuais.

\section{VI - PROTOCOLO DE PESQUISA}


O protocolo a ser submetido à revisão ética somente poderá ser apreciado se estiver instruído com os seguintes documentos, em português:

VI.1 - folha de rosto: título do projeto, nome, número da carteira de identidade, CPF, telefone e endereço para correspondência do pesquisador responsável e do patrocinador, nome e assinaturas dos dirigentes da instituição e/ou organização;

VI.2 - descrição da pesquisa, compreendendo os seguintes itens:

a) descrição dos propósitos e das hipóteses a serem testadas;

b) antecedentes científicos e dados que justifiquem a pesquisa. Se o propósito for testar um novo produto ou dispositivo para a saúde, de procedência estrangeira ou não, deverá ser indicada a situação atual de registro junto a agências regulatórias do país de origem;

c) descrição detalhada e ordenada do projeto de pesquisa (material e métodos, casuística, resultados esperados e bibliografia);

d) análise crítica de riscos e benefícios;

e) duração total da pesquisa, a partir da aprovação;

f) explicitaçao das responsabilidades do pesquisador, da instituição, do promotor e do patrocinador;

g) explicitação de critérios para suspender ou encerrar a pesquisa;

h) local da pesquisa: detalhar as instalações dos serviços, centros, comunidades e instituições nas quais se processarão as várias etapas da pesquisa;

i) demonstrativo da existência de infra-estrutura necessária ao desenvolvimento da pesquisa e para atender eventuais problemas dela resultantes, com a concordância documentada da instituição;

j) orçamento financeiro detalhado da pesquisa: recursos, fontes e destinação, bem como a forma e o valor da remuneração do pesquisador;

I) explicitação de acordo preexistente quanto à propriedade das informações geradas, demonstrando a inexistência de qualquer cláusula restritiva quanto à divulgação pública dos resultados, a menos que se trate de caso de obtenção de patenteamento; neste caso, os resultados devem se tornar públicos, tão logo se encerre a etapa de patenteamento;

m) declaração de que os resultados da pesquisa serão tornados públicos, sejam eles favoráveis ou não; e

n) declaração sobre o uso e destinação do material e/ou dados coletados.

VI.3 - informações relativas ao sujeito da pesquisa:

a) descrever as características da população a estudar: tamanho, faixa etária, sexo, cor (classificação do IBGE), estado geral de saúde, classes e grupos sociais, etc. Expor as razões para a utilização de grupos vulneráveis; pesquisa;

b) descrever os métodos que afetem diretamente os sujeitos da 
c) identificar as fontes de material de pesquisa, tais como espécimens, registros e dados a serem obtidos de seres humanos. Indicar se esse material será obtido especificamente para os propósitos da pesquisa ou se será usado para outros fins;

d) descrever os planos para o recrutamento de indivíduos e os procedimentos a serem seguidos. Fornecer critérios de inclusão e exclusão;

e) apresentar o formulário ou termo de consentimento, específico para a pesquisa, para a apreciação do Comitê de Ética em Pesquisa, incluindo informações sobre as circunstâncias sob as quais o consentimento será obtido, quem irá tratar de obtê-lo e a natureza da informação a ser fornecida aos sujeitos da pesquisa;

f) descrever qualquer risco, avaliando sua possibilidade e gravidade;

g) descrever as medidas para proteção ou minimização de qualquer risco eventual. Quando apropriado, descrever as medidas para assegurar os necessários cuidados à saúde, no caso de danos aos indivíduos. Descrever também os procedimentos para monitoramento da coleta de dados para prover a segurança dos indivíduos, incluindo as medidas de proteção à confidencialidade; $\mathrm{e}$

h) apresentar previsão de ressarcimento de gastos aos sujeitos da pesquisa. A importância referente não poderá ser de tal monta que possa interferir na autonomia da decisão do indivíduo ou responsável de participar ou não da pesquisa.

VI.4 - qualificação dos pesquisadores: "Curriculum vitae" do pesquisador responsável e dos demais participantes.

VI.5 - termo de compromisso do pesquisador responsável e da instituição de cumprir os termos desta Resolução.

\section{VII - COMITÊ DE ÉTICA EM PESQUISA-CEP}

Toda pesquisa envolvendo seres humanos deverá ser submetida à apreciação de um Comitê de Ética em Pesquisa.

VII.1 - As instituições nas quais se realizem pesquisas envolvendo seres humanos deverão constituir um ou mais de um Comitê de Ética em Pesquisa- CEP, conforme suas necessidades.

VII.2 - Na impossibilidade de se constituir CEP, a instituição ou o pesquisador responsável deverá submeter o projeto à apreciação do CEP de outra instituição, preferencialmente dentre os indicados pela Comissão Nacional de Ética em Pesquisa (CONEP/MS).

VII.3 - Organização - A organização e criação do CEP será da competência da instituição, respeitadas as normas desta Resolução, assim como o provimento de condições adequadas para o seu funcionamento.

VII.4 - Composição - O CEP deverá ser constituído por colegiado com número não inferior a 7 (sete) membros. Sua constituição deverá incluir a participação de profissionais da área de saúde, das ciências exatas, sociais e humanas, incluindo, por exemplo, juristas, teólogos, sociólogos, filósofos, 
bioeticistas e, pelo menos, um membro da sociedade representando os usuários da instituição. Poderá variar na sua composição, dependendo das especificidades da instituição e das linhas de pesquisa a serem analisadas.

VII.5 - Terá sempre caráter multi e transdisciplinar, não devendo haver mais que metade de seus membros pertencentes à mesma categoria profissional, participando pessoas dos dois sexos. Poderá ainda contar com consultores "ad hoc", pessoas pertencentes ou não à instituição, com a finalidade de fornecer subsídios técnicos.

VII.6 - No caso de pesquisas em grupos vulneráveis, comunidades e coletividades, deverá ser convidado um representante, como membro "ad hoc" do CEP, para participar da análise do projeto específico.

VII.7 - Nas pesquisas em população indígena deverá participar um consultor familiarizado com os costumes e tradições da comunidade.

VII.8 - Os membros do CEP deverão se isentar de tomada de decisão, quando diretamente envolvidos na pesquisa em análise.

VII.9 - Mandato e escolha dos membros - A composição de cada CEP deverá ser definida a critério da instituição, sendo pelo menos metade dos membros com experiência em pesquisa, eleitos pelos seus pares. A escolha da coordenação de cada Comitê deverá ser feita pelos membros que compõem o colegiado, durante a primeira reunião de trabalho. Será de três anos a duração do mandato, sendo permitida recondução.

VII.10 - Remuneração - Os membros do CEP não poderão ser remunerados no desempenho desta tarefa, sendo recomendável, porém, que sejam dispensados nos horários de trabalho do Comitê das outras obrigações nas instituições às quais prestam serviço, podendo receber ressarcimento de despesas efetuadas com transporte, hospedagem e alimentação.

VII.11 - Arquivo - O CEP deverá manter em arquivo o projeto, o protocolo e os relatórios correspondentes, por 5 (cinco) anos após o encerramento do estudo.

VII.12 - Liberdade de trabalho - Os membros dos CEPs deverão ter total independência na tomada das decisões no exercício das suas funções, mantendo sob caráter confidencial as informações recebidas. Deste modo, não podem sofrer qualquer tipo de pressão por parte de superiores hierárquicos ou pelos interessados em determinada pesquisa, devem isentarse de envolvimento financeiro e não devem estar submetidos a conflito de interesse.

\section{VII.13 - Atribuições do CEP:}

a) revisar todos os protocolos de pesquisa envolvendo seres humanos, inclusive os multicêntricos, cabendo-lhe a responsabilidade primária pelas decisões sobre a ética da pesquisa a ser desenvolvida na instituição, de modo a garantir e resguardar a integridade e os direitos dos voluntários participantes nas referidas pesquisas; 
b) emitir parecer consubstanciado por escrito, no prazo máximo de 30 (trinta) dias, identificando com clareza o ensaio, documentos estudados e data de revisão. A revisão de cada protocolo culminará com seu enquadramento em uma das seguintes categorias:

- aprovado;

- com pendência: quando o Comitê considera o protocolo como aceitável, porém identifica determinados problemas no protocolo, no formulário do consentimento ou em ambos, e recomenda uma revisão específica ou solicita uma modificação ou informação relevante, que deverá ser atendida em 60 (sessenta) dias pelos pesquisadores;

- retirado: quando, transcorrido o prazo, o protocolo permanece pendente;

- não aprovado; e

- aprovado e encaminhado, com o devido parecer, para apreciação pela Comissão Nacional de Ética em Pesquisa -CONEP/MS, nos casos previstos no capítulo VIII, item 4.c.

c) manter a guarda confidencial de todos os dados obtidos na execução de sua tarefa e arquivamento do protocolo completo, que ficará à disposição das autoridades sanitárias;

d) acompanhar o desenvolvimento dos projetos através de relatórios anuais dos pesquisadores;

e) desempenhar papel consultivo e educativo, fomentando a reflexão em torno da ética na ciência;

f) receber dos sujeitos da pesquisa ou de qualquer outra parte denúncias de abusos ou notificação sobre fatos adversos que possam alterar o curso normal do estudo, decidindo pela continuidade, modificação ou suspensão da pesquisa, devendo, se necessário, adequar o termo de consentimento. Considera-se como anti-ética a pesquisa descontinuada sem justificativa aceita pelo CEP que a aprovou;

g) requerer instauração de sindicância à direção da instituição em caso de denúncias de irregularidades de natureza ética nas pesquisas e, em havendo comprovação, comunicar à Comissão Nacional de Ética em Pesquisa-CONEP/MS e, no que couber, a outras instâncias; e

h) manter comunicação regular e permanente com a CONEP/MS.

VII.14 - Atuação do CEP:

a) A revisão ética de toda e qualquer proposta de pesquisa envolvendo seres humanos não poderá ser dissociada da sua análise científica. Pesquisa que não se faça acompanhar do respectivo protocolo não deve ser analisada pelo Comitê.

b) Cada CEP deverá elaborar suas normas de funcionamento, contendo metodologia de trabalho, a exemplo de: elaboração das atas; planejamento anual de suas atividades; periodicidade de reuniões; número mínimo de presentes para início das reuniões; prazos para emissão de 
pareceres; critérios para solicitação de consultas de experts na área em que se desejam informações técnicas; modelo de tomada de decisão, etc.

\section{(CONEP/MS)}

VIII - COMISSÃO NACIONAL DE ÉTICA EM PESQUISA

A Comissão Nacional de Ética em Pesquisa - CONEP/MS é uma instância colegiada, de natureza consultiva, deliberativa, normativa, educativa, independente, vinculada ao Conselho Nacional de Saúde.

O Ministério da Saúde adotará as medidas necessárias para o funcionamento pleno da Comissão e de sua Secretaria Executiva.

VIII.1 - Composição: A CONEP terá composição multi e transdiciplinar, com pessoas de ambos os sexos e deverá ser composta por 13 (treze) membros titulares e seus respectivos suplentes, sendo 05 (cinco) deles personalidades destacadas no campo da ética na pesquisa e na saúde e 08 (oito) personalidades com destacada atuação nos campos teológico, jurídico e outros, assegurando-se que pelo menos um seja da área de gestão da saúde. Os membros serão selecionados, a partir de listas indicativas elaboradas pelas instituições que possuem CEP registrados na CONEP, sendo que 07 (sete) serão escolhidos pelo Conselho Nacional de Saúde e 06 (seis) serão definidos por sorteio. Poderá contar também com consultores e membros "ad hoc", assegurada a representação dos usuários.

VIII.2 - Cada CEP poderá indicar duas personalidades.

VIII.3 - O mandato dos membros da CONEP será de quatro anos com renovação alternada a cada dois anos, de sete ou seis de seus membros.

VIII.4 - Atribuições da CONEP - Compete à CONEP o exame dos aspectos éticos da pesquisa envolvendo seres humanos, bem como a adequação e atualização das normas atinentes. A CONEP consultará a sociedade sempre que julgar necessário, cabendo-lhe, entre outras, as seguintes atribuições:

a) estimular a criação de CEPs institucionais e de outras instâncias;

b) registrar os CEPs institucionais e de outras instâncias;

c) aprovar, no prazo de 60 dias, e acompanhar os protocolos de pesquisa em áreas temáticas especiais tais como:

1- genética humana;

2- reprodução humana;

3- farmácos, medicamentos, vacinas e testes diagnósticos novos (fases I, II e III) ou não registrados no país (ainda que fase IV), ou quando a pesquisa for referente a seu uso com modalidades, indicações, doses ou vias de administração diferentes daquelas estabelecidas, incluindo seu emprego em combinações;

4- equipamentos, insumos e dispositivos para a saúde novos, ou não registrados no país;

5- novos procedimentos ainda não consagrados na literatura;

6- populações indígenas; 
7- projetos que envolvam aspectos de biossegurança;

8- pesquisas coordenadas do exterior ou com participação estrangeira e pesquisas que envolvam remessa de material biológico para o exterior; e

9- projetos que, a critério do CEP, devidamente justificado, sejam julgados merecedores de análise pela CONEP;

d) prover normas específicas no campo da ética em pesquisa, inclusive nas áreas temáticas especiais, bem como recomendações para aplicação das mesmas;

e) funcionar como instância final de recursos, a partir de informações fornecidas sistematicamente, em caráter ex-ofício ou a partir de denúncias ou de solicitação de partes interessadas, devendo manifestar-se em um prazo não superior a 60 (sessenta) dias;

f) rever responsabilidades, proibir ou interromper pesquisas, definitiva ou temporariamente, podendo requisitar protocolos para revisão ética inclusive, os já aprovados pelo CEP;

g) constituir um sistema de informação e acompanhamento dos aspectos éticos das pesquisas envolvendo seres humanos em todo o território nacional, mantendo atualizados os bancos de dados;

h) informar e assessorar o MS, o CNS e outras instâncias do SUS, bem como do governo e da sociedade, sobre questões éticas relativas à pesquisa em seres humanos;

i) divulgar esta e outras normas relativas à ética em pesquisa envolvendo seres humanos;

j) a CONEP juntamente com outros setores do Ministério da Saúde, estabelecerá normas e critérios para o credenciamento de Centros de Pesquisa. Este credenciamento deverá ser proposto pelos setores do Ministério da Saúde, de acordo com suas necessidades, e aprovado pelo Conselho Nacional de Saúde; e

I) estabelecer suas próprias normas de funcionamento.

VIII.5 - A CONEP submeterá ao CNS para sua deliberação:

a) propostas de normas gerais a serem aplicadas às pesquisas envolvendo seres humanos, inclusive modificações desta norma;

b) plano de trabalho anual;

c) relatório anual de suas atividades, incluindo sumário dos CEP estabelecidos e dos projetos analisados.

IX - OPERACIONALIZAÇÃO

IX.1 - Todo e qualquer projeto de pesquisa envolvendo seres humanos deverá obedecer às recomendações desta Resolução e dos documentos endossados em seu preâmbulo. A responsabilidade do pesquisador é indelegável, indeclinável e compreende os aspectos éticos e leagis.

IX.2 - Ao pesquisador cabe: 
a) apresentar o protocolo, devidamente instruido ao CEP, aguardando o pronunciamento deste, antes de iniciar a pesquisa;

b) desenvolver o projeto conforme delineado;

c) elaborar e apresentar os relatórios parciais e final;

d) apresentar dados solicitados pelo CEP, a qualquer momento;

e) manter em arquivo, sob sua guarda, por 5 anos, os dados da pesquisa, contendo fichas individuais e todos os demais documentos recomendados pelo CEP;

f) encaminhar os resultados para publicação, com os devidos créditos aos pesquisadores associados e ao pessoal técnico participante do projeto;

g) justificar, perante o CEP, interrupção do projeto ou a não publicação dos resultados.

IX.3 - O Comitê de Ética em Pesquisa institucional deverá estar registrado junto à CONEP/MS.

IX.4 - Uma vez aprovado o projeto, o CEP passa a ser co-responsável no que se refere aos aspectos éticos da pesquisa.

IX.5 - Consideram-se autorizados para execução, os projetos aprovados pelo CEP, exceto os que se enquadrarem nas áreas temáticas especiais, os quais, após aprovação pelo CEP institucional deverão ser enviados à CONEP/MS, que dará o devido encaminhamento.

IX.6 - Pesquisas com novos medicamentos, vacinas, testes diagnósticos, equipamentos e dispositivos para a saúde deverão ser encaminhados do CEP à CONEP/MS e desta, após parecer, à Secretaria de Vigilância Sanitária.

IX.7 - As agências de fomento à pesquisa e o corpo editorial das revistas científicas deverão exigir documentação comprobatória de aprovação do projeto pelo CEP e/ou CONEP, quando for o caso.

IX.8 - Os CEP institucionais deverão encaminhar trimestralmente à CONEP/MS a relação dos projetos de pesquisa analisados, aprovados e concluídos, bem como dos projetos em andamento e, imediatamente, aqueles suspensos.

\section{DISPOSIÇÕES TRANSITÓRIAS}

X.1 - O Grupo Executivo de Trabalho-GET, constituido através da Resolução CNS 170/95, assumirá as atribuições da CONEP até a sua constituição, responsabilizando-se por:

a) tomar as medidas necessárias ao processo de criação da CONEP/MS;

b) estabelecer normas para registro dos CEP institucionais;

X.2 - O GET terá 180 dias para finalizar as suas tarefas.

X.3 - Os CEP das instituições devem proceder, no prazo de 90 (noventa) dias, ao levantamento e análise, se for o caso, dos projetos de pesquisa em seres humanos já em andamento, devendo encaminhar à CONEP/MS, a relação dos mesmos. 
X4 - Fica revogada a Resolução 01/88.

\section{ADIB D. JATENE}

Presidente do Conselho Nacional de Saúde

Homologo a Resolução CNS no 196, de 10 de outubro de 1996, nos termos do Decreto de Delegação de Competência de 12 de novembro de 1991.

\section{ADIB D. JATENE}

Ministro de Estado da Saúde 